Andrews University

Digital Commons @ Andrews University

Master's Theses

Graduate Research

2020

\title{
The Casemate Wall System of Khirbat Safra
}

Elizabeth Anne Emswiler

Andrews University, emswiler@andrews.edu

Follow this and additional works at: https://digitalcommons.andrews.edu/theses

Part of the Ancient, Medieval, Renaissance and Baroque Art and Architecture Commons

\section{Recommended Citation}

Emswiler, Elizabeth Anne, "The Casemate Wall System of Khirbat Safra" (2020). Master's Theses. 156. https://dx.doi.org/10.32597/theses/156

https://digitalcommons.andrews.edu/theses/156

This Thesis is brought to you for free and open access by the Graduate Research at Digital Commons @ Andrews University. It has been accepted for inclusion in Master's Theses by an authorized administrator of Digital Commons@Andrews University. For more information, please contact repository@andrews.edu. 
ABSTRACT

THE CASEMATE WALL SYSTEM OF KHIRBAT SAFRA

by

Elizabeth Anne Emswiler

Adviser: Paul J. Ray 


\title{
ABSTRACT OF GRADUATE STUDENT RESEARCH
}

Thesis

\author{
Andrews University \\ Seventh-day Adventist Theological Seminary
}

\section{Title: THE CASEMATE WALL SYSTEM OF KHIRBAT SAFRA}

Name of researcher: Elizabeth Emswiler

Name and degree of faculty advisor: Paul J. Ray, Ph.D.

Date completed:

\section{Problem}

A casemate wall system was found at Khirbat Safra in 2018 and 2019, which has been dated to early Iron Age I. However, no comprehensive study of Iron Age I casemate wall systems in Transjordan has been conducted. Therefore, this thesis will present and compare the findings from Kh. Safra and four other sites in Transjordan which have casemate wall systems dating to Iron Age I.

\section{Method}

A short study on the history of fortifications, casemate wall systems, and siege warfare was conducted for this thesis. The ruins from Fields A, B, C, and D at Kh. Safra 
were then examined along with the ruins of four other Iron Age I casemate wall systems in Transjordan. Lastly, the features of these five casemate wall systems were compared.

\section{Results}

Parallels to the casemate wall system of Kh. Safra were found at four sites throughout Transjordan. A comparison of the parallels helps to understand the form and function of the Iron Age I casemate wall systems found in Transjordan so far.

\section{Conclusions}

It was possible to conclude that the casemate wall system of $\mathrm{Kh}$. Safra is unique in terms of its location (being the only Iron Age I casemate wall system in its region) but not in terms of its form and function. Rather, Kh. Safra and the four other Iron Age I casemate wall systems in Transjordan share many similarities both architecturally and potentially through the purpose these defensive walls served. 
Andrews University

Seventh-day Adventist Theological Seminary

\title{
THE CASEMATE WALL SYSTEM OF KHIRBAT SAFRA
}

\author{
A Thesis \\ Presented in Partial Fulfillment \\ of the Requirements for the Degree \\ Master of Arts
}

by

Elizabeth Anne Emswiler

2020 
(C) Copyright by Elizabeth Anne Emswiler 2020 All Rights Reserved 


\title{
THE CASEMATE WALL SYSTEM OF KHIRBAT SAFRA
}

\author{
A thesis \\ presented in partial fulfillment \\ of the requirements for the degree \\ Master of Arts
}

by

Elizabeth Anne Emswiler

APPROVAL BY THE COMMITTEE:

Paul J. Ray, Ph.D., Chair

Paul Zeljko Gregor, Ph.D.

Date approved 


\section{TABLE OF CONTENTS}

LIST OF FIGURES ….......................................................................

Chapter

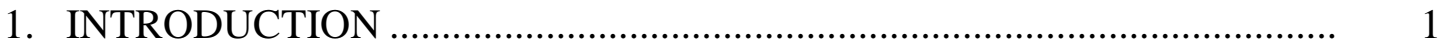

2. CASEMATE WALL SYSTEMS ........................................................ 3

Brief History of the Development of Fortifications .................................. 3

General Description of Casemate Wall Systems of the

Ancient Near East....................................................................... 4

Origin and Early Examples of the Casemate Wall System ....................... 5

Casemate Wall Systems and Siege Warfare ........................................... 10

3. THE CASEMATE WALL SYSTEM OF KHIRBAT SAFRA ..................... 16

Introduction to Khirbat Safra................................................................ 16

Casemate Wall System in Field A ......................................................... 16

Field A Square 1 - Casemate Wall System........................................ 19

Field A Square 3 ...................................................................... 20

Casemate Wall System in Field B ......................................................... 21

Field B Squares 1 and 3 - Casemate Wall System ........................... 21

Field B Squares 1-6 - Buildings 1 and 2 ......................................... 24

Casemate Wall System in Field C ........................................................... 25

Field C Square 1 - Casemate Wall System........................................ 27

Field C Square 1 and 2 - Rooms North of Casemate Wall System ....... 28

Casemate Wall System in Field D ......................................................... 29

Field D Squares 3, 4, and 6 - Casemate Wall System ....................... 30

Field D Squares 3 and 5 - City Gate Complex ................................. 31

Field D Squares 1, 2, and 6 - Interior Buildings/Phasing ................... 32

Summary of Casemate Wall System .................................................... 33

Preliminary Conclusions ................................................................. 33

4. IRON AGE I CASEMATE WALL SYSTEMS IN TRANSJORDAN .......... 35

Khirbat al-Ma'mariyah.................................................................. 35

Khirbat al-Mudayna al-'Aliya ............................................................... 46

Casemate Wall System of Khirbat al-Mudayna al-'Aliya................... 50

Ceramics of Khirbat al-Mudayna al-'Aliya ...................................... 57 
Khirbat al-Mudayna al-Mu'arrajah ...................................................... 61

Casemate Wall System of Khirbat al-Mudayna al-Mu'arrajah............. 61

Ceramics of Khirbat al-Mudayna al-Mu'arrajah.................................. 67

Khirbat al-Lahun ................................................................. 70

5. COMPARISON BETWEEN SIMILAR CASEMATE WALL STRUCTURES ……………………....................................................... 74

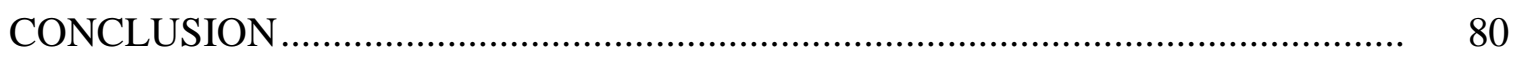

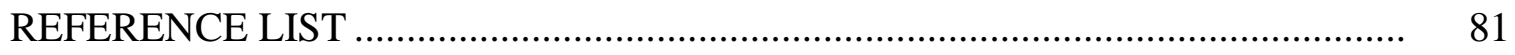




\section{LIST OF FIGURES}

1. Example of a Casemate Wall ....................................................................... 5

2. Caissons Wall at Alishar and Casemate-Like Wall at Boğazköy .......................... 6

3. Plan of MB IIC-LB I Casemate at Tell Ta'annek................................................. 8

4. Commercial Complex (Bakery) with City Wall and One Casemate Room from Stratum IIB (First Half of Late Bronze Age) at Abu al-Kharaz ..................... 8

5. Stratum III in Area $\mathrm{K}$ at Hazor Showing Casemate Walls in Connection with the City Gate .........................................................................................

6. Casemate Wall E, Part of Field IV at Shechem ....................................................

7. Casemate Wall System in Area 1 at Zira'a .............................................................. 11

8. Casemate Wall System on North, West, and South Side of Iron I Settlement

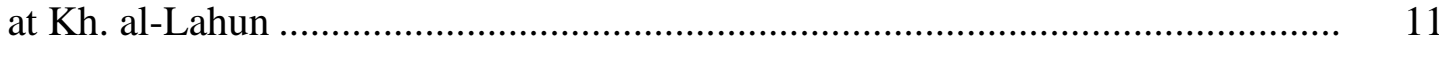

9. A Primitive Battering Ram Depicted on a Wall Painting from Beni-Hasan ......... 12

10. Assyrian Siege Engine Attacking Lachish............................................................ 14

11. An Assyrian Attack on a City with a Battering Ram......................................... 14

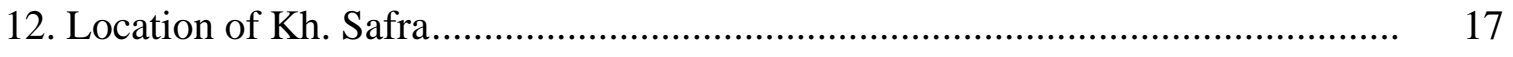

13. Topographic Map of Kh. Safra with Excavation Fields .................................... 18

14. The Casemate Wall System of Kh. Safra.......................................................... 18

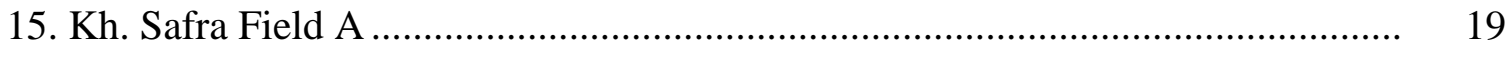

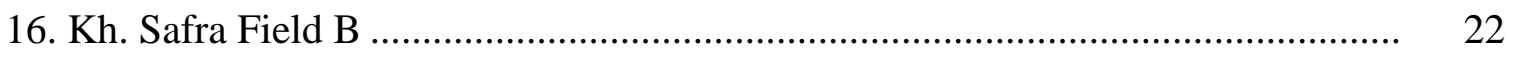

17. Kh. Safra Field B3 East Balk .................................................................... 24

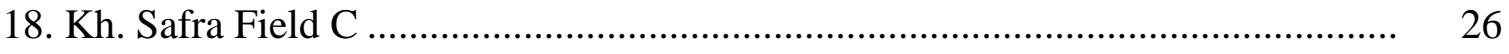


19. Kh. Safra Field C1 North Balk

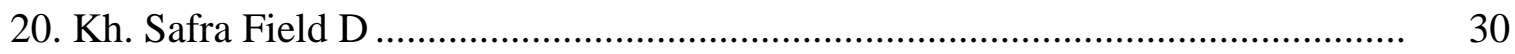

21. Chart Representing Objects Found in 2018 and 2019 Seasons at Kh. Safra ......... 34

22. Map of Sites with Iron Age I Casemate Wall Systems in Transjordan ................ 36

23. Aerial of Kh. al-Ma'mariyah ............................................................................ 37

24. Region of the Wadi ash-Shkafiya Survey ……………....................................... 38

25. Citadel at Kh. al-Ma'mariyah .......................................................................... 40

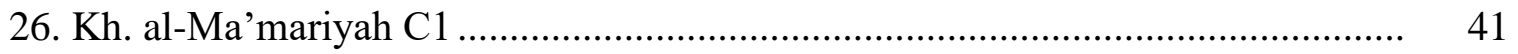

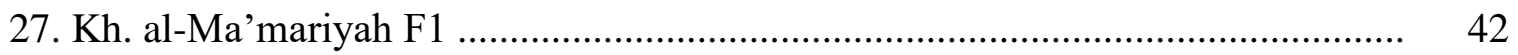

28. Kh. al-Ma'mariyah Area G .................................................................... 42

29. Grinding Stones Found in Area G of Kh. al-Ma'mariyah ..................................... 43

30. Iron Age I Pottery Assemblage from Kh. al-Ma'mariyah, 1 ............................... 44

31. Iron Age I Pottery Assemblage from Kh. al-Ma'mariyah, 2 ………………...... 45

32. Map of South-Central Jordan Showing Location of Kh. al-Mudayna al-'Aliya ... 47

33. Aerial Image of Kh. al-Mudayna al- 'Aliya, Looking North................................. 48

34. Top Plan of the Architecture and Topography at Kh. al-Mudayna al-'Aliya ........ 49

35. Top Plan of Building 100 at Kh. al-Mudayna al-'Aliya ...................................... 52

36. Top Plan of Building 300 at Kh. al-Mudayna al-'Aliya ...................................... 53

37. Top Plan of Building 400 at Kh. al-Mudayna al-'Aliya ...................................... 53

38. Top Plan of Building 800 at Kh. al-Mudayna al-'Aliya ...................................... 54

39. Top Plan of Building 200 at Kh. al-Mudayna al-'Aliya ....................................... 54

40. Top Plan of Building 500 at Kh. al-Mudayna al-'Aliya ..................................... 55

41. Top Plan of Building 700 at Kh. al-Mudayna al-'Aliya ...................................... 56 
42. Top Plan of Building 600 at Kh. al-Mudayna al-'Aliya .................................. 56

43. Iron Age I Bowls from Kh. al-Mudayna al-'Aliya ........................................ 58

44. Iron Age I Bowls, Kraters, and Cooking Jugs from Kh. al-Mudayna al-'Aliya.... 59

45. Iron Age I Storage Jars, Jars, and Jugs from Kh. al-Mudayna al-‘Aliya .............. 60

46. Topography of Kh. al-Mudayna al-Mu'arrajah ............................................. 62

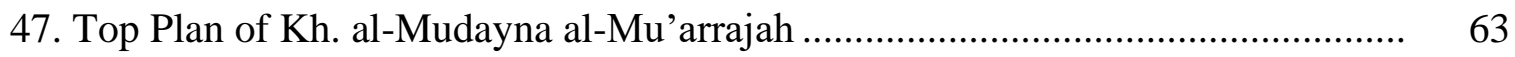

48. City Gate and House at Kh. al-Mudayna al-Mu'arrajah ................................... 64

49. Towers 1-3 at Kh. al-Mudayna al-Mu'arrajah ............................................... 68

50. Iron Age I Pottery Assemblage from Kh. al-Mudayna al-Mu'arrajah.................. 69

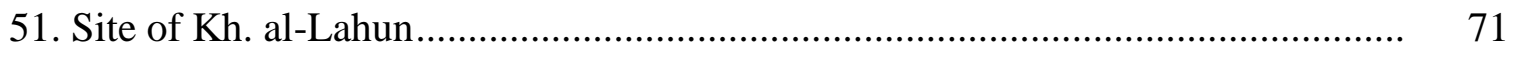

52. Top Plan of Iron Age Settlement and Fortress at Kh. al-Lahun ........................ 72

53. Comparison the Casemate Wall Systems Discussed in this Paper ..................... 75

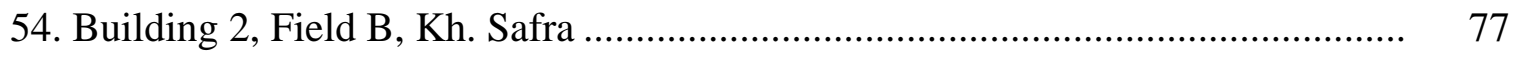

55. Building 400 at Kh. al-Mudayna al-'Aliya .................................................. 78 


\section{CHAPTER 1}

\section{INTRODUCTION}

Casemate wall systems are relatively common throughout the Southern Levant beginning in the Middle Bronze Age and ending in Iron Age II. Recently, a casemate wall system dating to Iron Age I was discovered at Khirbat Safra, a site at which excavations began in the 2018 season. Under the direction of Paul Gregor, Constance Gane, and Paul Ray of the Institute of Archaeology at Andrews University, four fields

were opened. Each field revealed part of a casemate wall system. Approximately $17 \mathrm{~km}$ southwest of Madaba, this site appears to have had three occupational phases with the earliest settlement (during Iron Age I) being the origin for most of the architecture including the casemate wall system.

The present study starts with a short look at the history of fortifications, casemate wall systems, and siege warfare. It summarizes the development of fortifications, the origin of the casemate wall system, and looks at how developments in siege warfare made the casemate style fall out of use. Following that, an examination of the casemate wall system at Kh. Safra is presented. As excavation at Kh. Safra has just recently begun, there are very few publications that have been written on this site. Only two preliminary reports have been written which along with the field notebooks will be the primary sources of information for the data in Chapter 2. Then, a survey was conducted of four Iron Age I casemate wall systems in Transjordan (Khirbat al-Ma'mariyah, Khirbat al- 
Mudayna al-'Aliya, Khirbat al-Mudayna al-Mu'arrajah, and Khirbat al-Lahun) with a brief introduction to the site, a history of the excavations, and a presentation of the available data regarding the fortifications. Finally, the casemate wall system at $\mathrm{Kh}$. Safra will be compared to those four casemate wall systems, specifically regarding their form and function.

This thesis is a descriptive project and therefore does not bring any new data or solutions and does not attempt to identify the site. Rather, the aim of this thesis is to describe and investigate the casemate wall system of Kh. Safra and look for comparisons with the other Iron Age I casemate wall systems in Transjordan. 


\section{CHAPTER 2}

\section{CASEMATE WALL SYSTEMS}

\section{Brief History of the Development of Fortifications}

Fortifications became prominent in the Southern Levant during the Early Bronze

Age (henceforth EB). Permanent settlements formed and people groups became attached to a specific region often because of that region's abundant resources. There was then a need to defend their homes and belongings. Fortifications developed as a way to protect the core of a settlement which often consisted of public buildings, homes, and stored resources. The need for protection resulted from an increase in attacks by neighboring settlements, nomads, and seminomads. The most common types of fortification elements consisted of city walls, towers, gatehouses, glacis, ramparts, bastions, and fosses or moats.

Throughout the EB, city walls developed from a single narrow wall in EBI (1.5 to $3.0 \mathrm{~m}$ thick) to a single thick wall in EBIII (8.0 to $10 \mathrm{~m}$ thick; Kempinski 1992a: 68). Many city walls reverted to a narrower thickness during the Middle Bronze Age (henceforth MB) often between 2.0 and 4.0 m thick (Kempinski 1992b: 127). It is in this period where the regions earliest casemate wall systems are found (Lapp, N. 1976: 25). Generally, no new city walls were built in the Late Bronze (henceforth LB). Most cities either reused the preexisting MB walls or the settlement lacked fortifications all together (Gonen 1984: 62). The Iron Age brings a wider range of settlement types from capital 
cities and administrative cities, to provincial towns and villages. The variety of settlement types also brought in a variety of fortifications based on that settlement's need and available resources. For city walls this meant an increase in the usage of casemate walls and the development of multiple sub-types of massive walls as well as the implementation of a simple peripheral belt of houses (Herzog 1992: 270).

\section{General Description of Casemate Wall Systems of the Ancient Near East}

Casemate wall systems, while most common during Iron Age II, appear as early as the MB (Burke 2008: 59). Most fortification walls in the MB were built thicker in order to withstand attacks, commonly called massive or solid walls and found in Cyclopean or Hyksos style fortifications. However, building this type of fortification took more time, manpower, and supplies. Casemate wall systems provided an alternative type of fortification which were easier to build. These systems are comprised of two thinner, parallel walls with a varying amount of space between them. Transverse walls were built within these spaces which separated the area between the city walls into small rooms (Figure 1). These rooms could then be used for storage and extra living space during times of peace or they could easily be filled in with rocks and soil in order to create a thicker fortification wall. While sometimes constructed around the entire settlement, most casemate-style walls were used only for a part of the settlement's defenses.

There are three main types of casemate wall systems found throughout the Southern Levant. Freestanding casemate walls are where the inner casemate walls are separated from the buildings within the settlement. In this case, the entrances to the casemate rooms would often lead out to a road. Integrated casemate walls are when the 


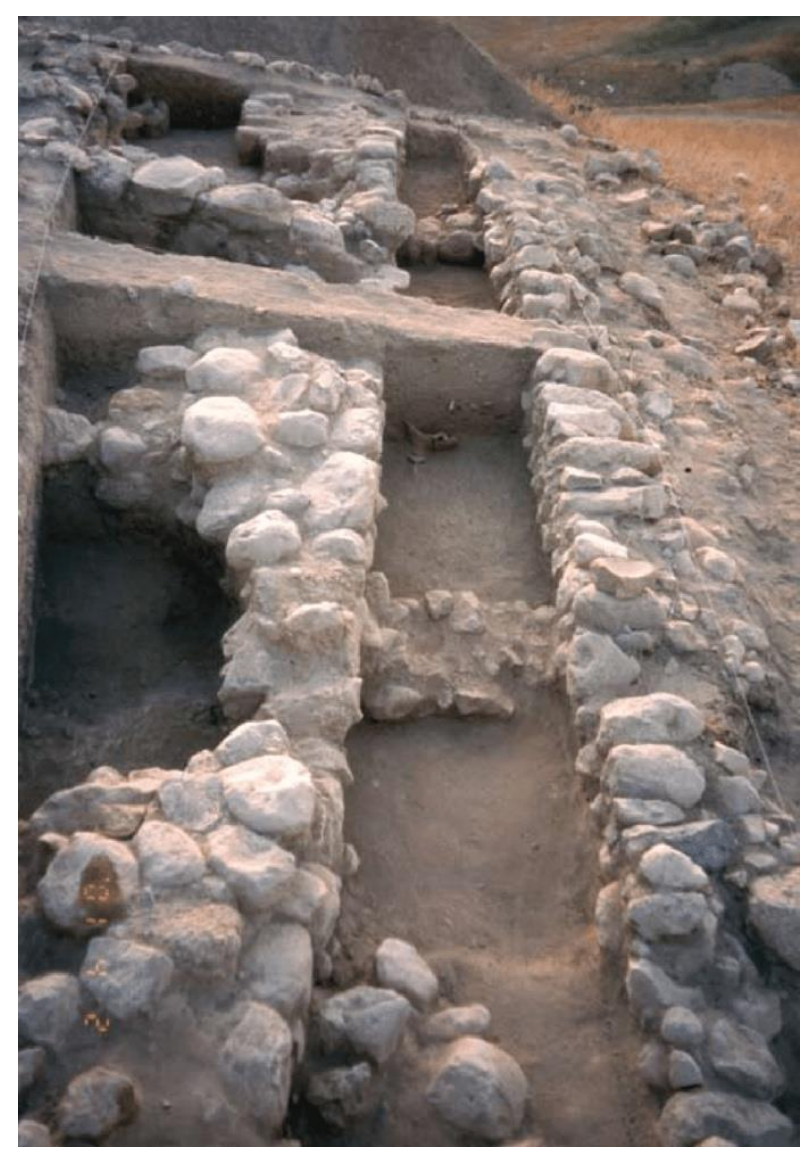

Figure 1. Example of a casemate wall at Tall Abu al-Kharaz (from Fischer 2008: 202).

inner casemate wall is integrated into the buildings within the settlement. The third type is known as a filled casemate wall. In this type of fortification, the rooms were never meant to be used. Instead they were built in the casemate style and quickly filled with soil. The filled casemate wall often occurred when the wall needed to be built to a greater height but still quickly, as this building technique provided a more stable framework.

\section{Origin and Early Examples of the Casemate Wall System}

It had long been presumed that the construction of casemate wall systems began in Asia Minor in the MB and LB and didn't reach Cisjordan until Iron Age I, and then only through Syrian mediation. Alexander Badawy, an Egyptologist, argued that the 
casemate wall derived from the caisson type construction which was perfected during the second millennium B.C. He proposed that it "evolved rapidly from a row of contiguous square walled-in compartments, like that of Alishar to a system of two thick parallel walls bound with transverse partitions and having towers that projected at regular intervals, which can be seen at Boğazköy” (Figure 2; Badawy 1966: 142). While these rooms were generally not large enough to be used as living space there is evidence that they were used "for storage or as blockhouses for firing" (Badawy 1966: 142).

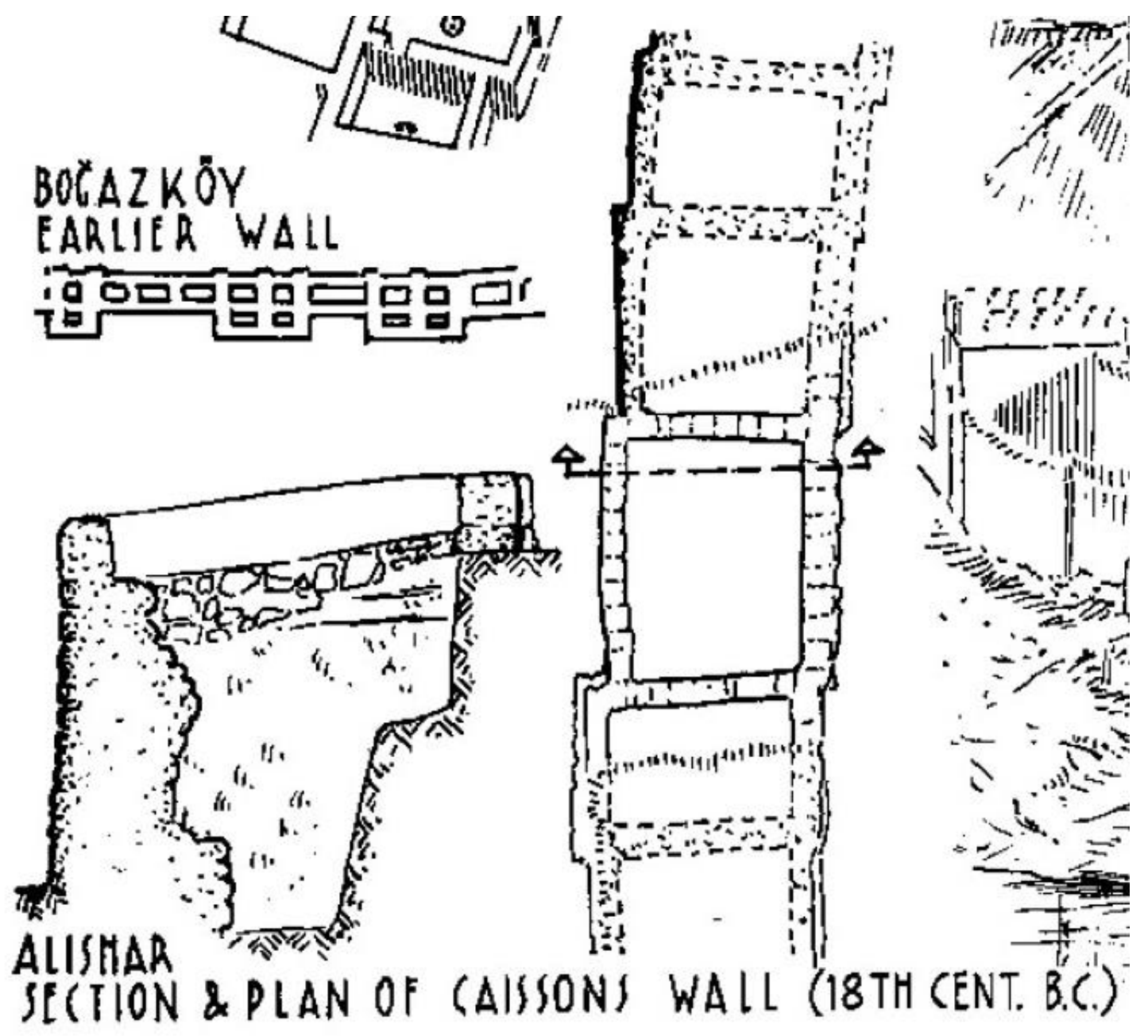

Figure 2. Caissons wall at Alishar and casemate-like wall at Boğazköy (from Badawy 1966: 142). 
While discussing the origins of the casemate wall system, W.F. Albright wrote,

The casemate wall is an excellent example of a type which enjoyed great vogue in Palestine in the eleventh and tenth centuries, and continued in sporadic use into the latter part of Iron II. This type of wall originated in Late Bronze Asia Minor, and was brough to Syria by the Hittites; from Syria it spread southward during the transition from Bronze to Iron (Albright, 1960: 120-21).

Yigael Yadin, after discovering a casemate at Tel Megiddo in 1960, described the

origin of casemate wall systems as the following:

Casemate fortifications were introduced, as we have seen, in the Middle Bronze period, and they were developed largely under the Hittite Empire in the Late Bronze period.... The idea presumable travelled from here to Syria and Palestine, for in the period of the Neo-Hittite and Aramaic kingdoms, beginning from the $11^{\text {th }}$ century, the casemate system was widely adopted.... In Palestine, the casemate made its appearance even before the Solomonic period, and one of the best examples was discovered at Gibeah.... Casemate walls were also found in other cities of Palestine.... These fortifications cannot be specifically ascribed to Solomon, and they may well have been built in the time of David.... We can take it, then, as a general rule that the guiding signs for the identification of Solomonic fortifications are the casemate wall, together with the six-chamber gate and twin towers. Casemated city walls, without this type of gate, are no guarantee of Solomonic origin, for such walls were built also in the period of Saul and David. In the same way, casemated walls of inner citadels or isolated fortresses do not necessarily belong to this early period and they may well belong to the Divided Monarchy in the period of Iron Age II (Yadin 1963: 289-90).

However, after a casemate wall system was discovered at Tell Ta'annek which was dated to the first phase of the later MB IIC-LB I defense system (Figure 3), Paul Lapp contended "that the casemate can no longer be cited as an instance of Palestinian cultural lag. It [Ta'annek] provides the clearest evidence to date on the origin of the casemate in Palestine, and perhaps for the entire Near East" (Lapp, P. 1969: 22).

Archaeologists have since discovered multiple examples of casemate wall systems which date to the MB. Besides Ta'annek, substantial casemate walls have been discovered at Tell Abu al-Kharaz (Figure 4) in Strata IIa-c dating to MB IIC (Fischer 1998, 215-16), Tell el-Far'ah (South) dating to MB IIB-C (Gophna 1993: 441), Tel 


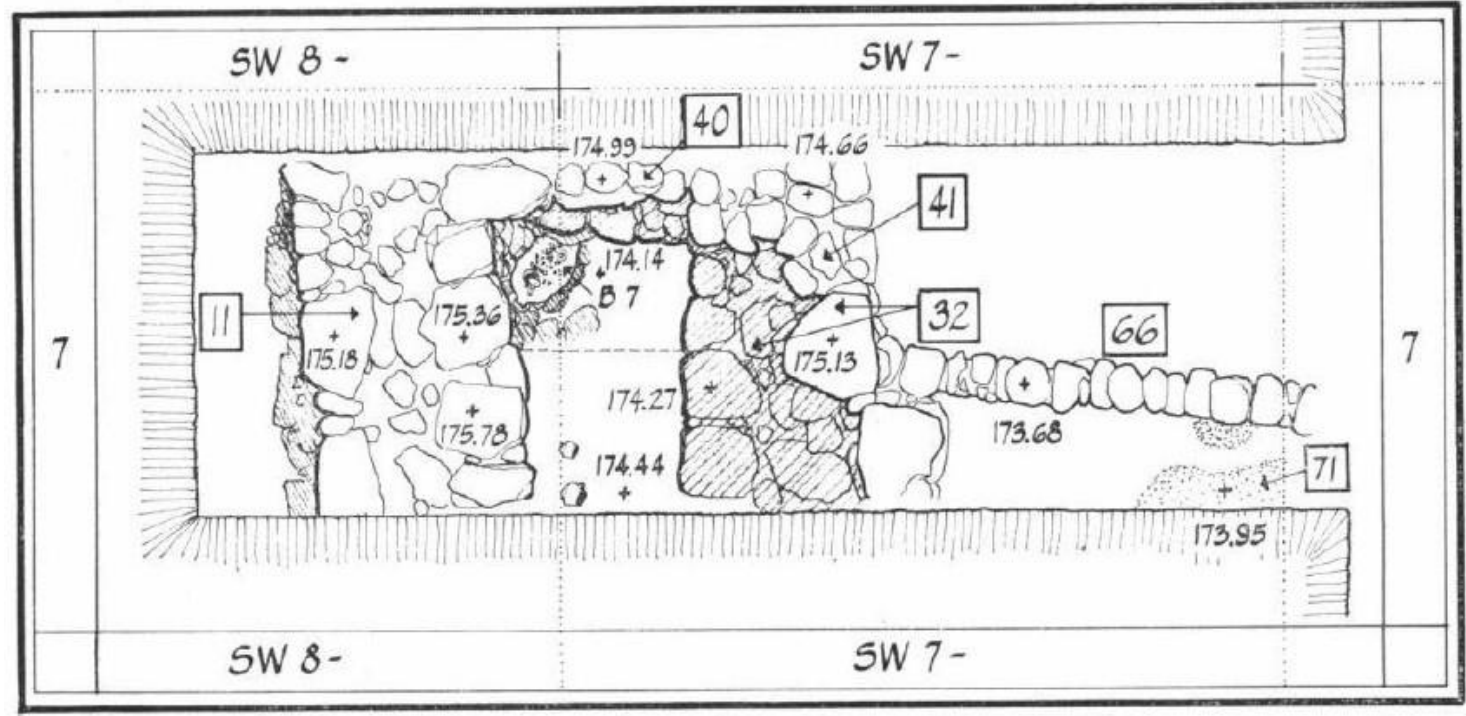

Figure 3. Plan of MB IIC-LB I casemate at Tell Ta'annek (from Lapp, P. 1969: 18).

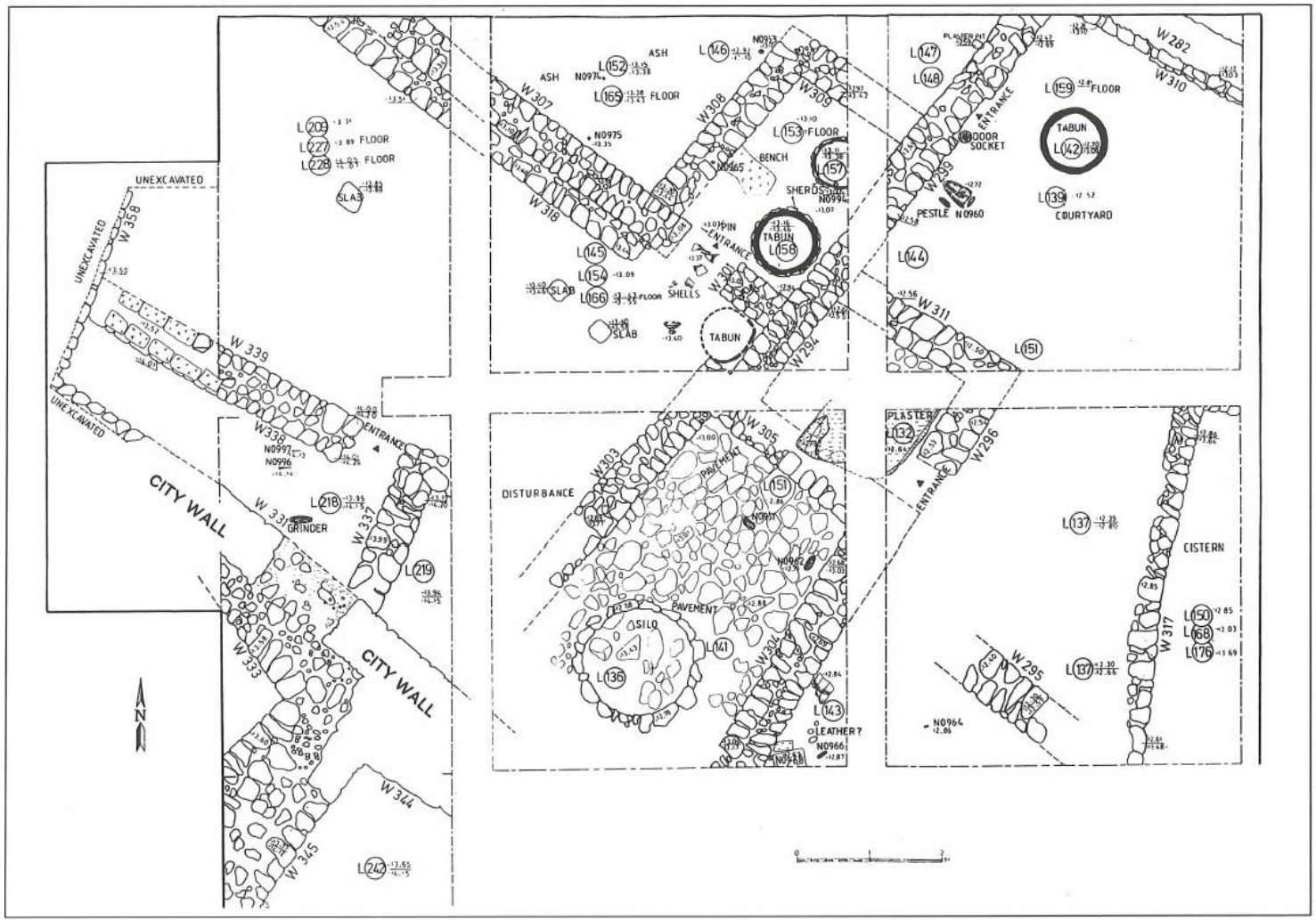

Figure 4. Commercial complex (bakery) with city wall and one casemate room from Stratum IIB (first half of Late Bronze Age) at Abu al-Kharaz (from Fischer 1997: 133). 
Hazor (Figure 5) in Stratum III dating to MB IIC (Yadin, et al. 1989: 282-83), and Tell Balata/Shechem (Figure 6) in Stratum XV dating to MB IIC (Dever 1974: 39). Each of these sites represents further proof that there was no Palestinian cultural lag when it comes to the introduction of casemate wall systems.

The LB, especially in Cisjordan, is a period which lacks innovation in the art of fortification with only a few notable exceptions. Hazor, Shechem, and Megiddo each

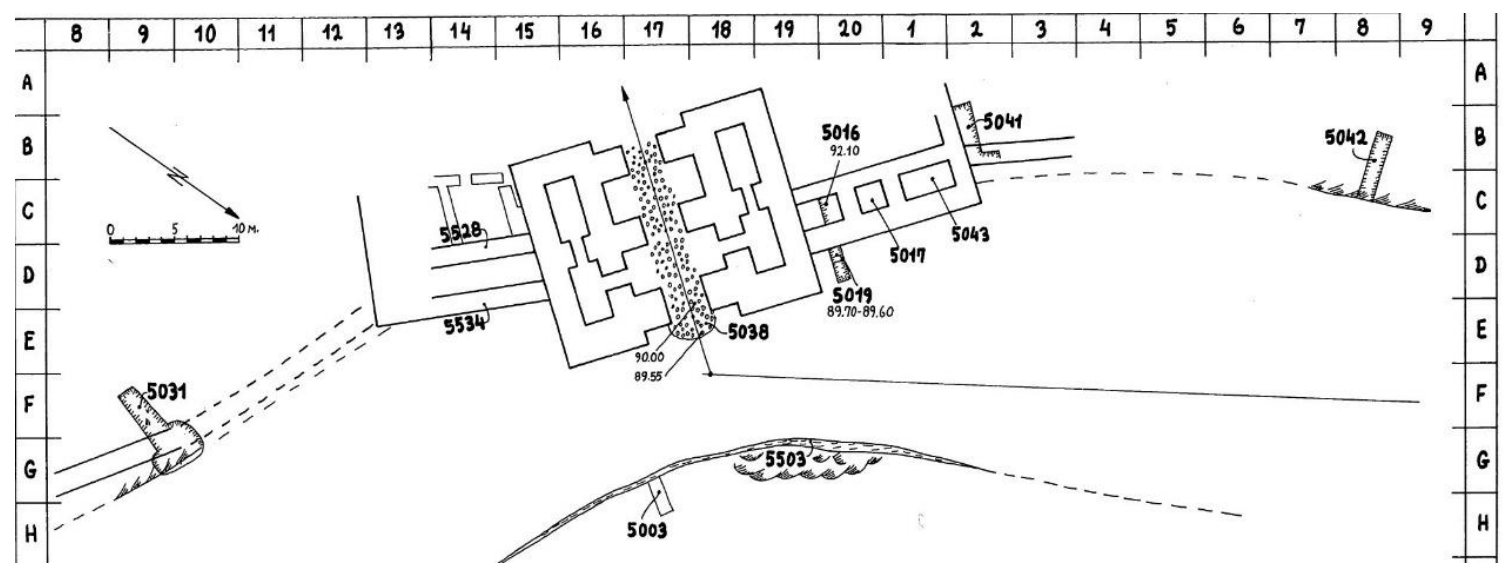

Figure 5. Stratum III in Area $\mathrm{K}$ at Hazor showing casemate walls in connection with the city gate (from Yadin, et al. 1989: 282-83).

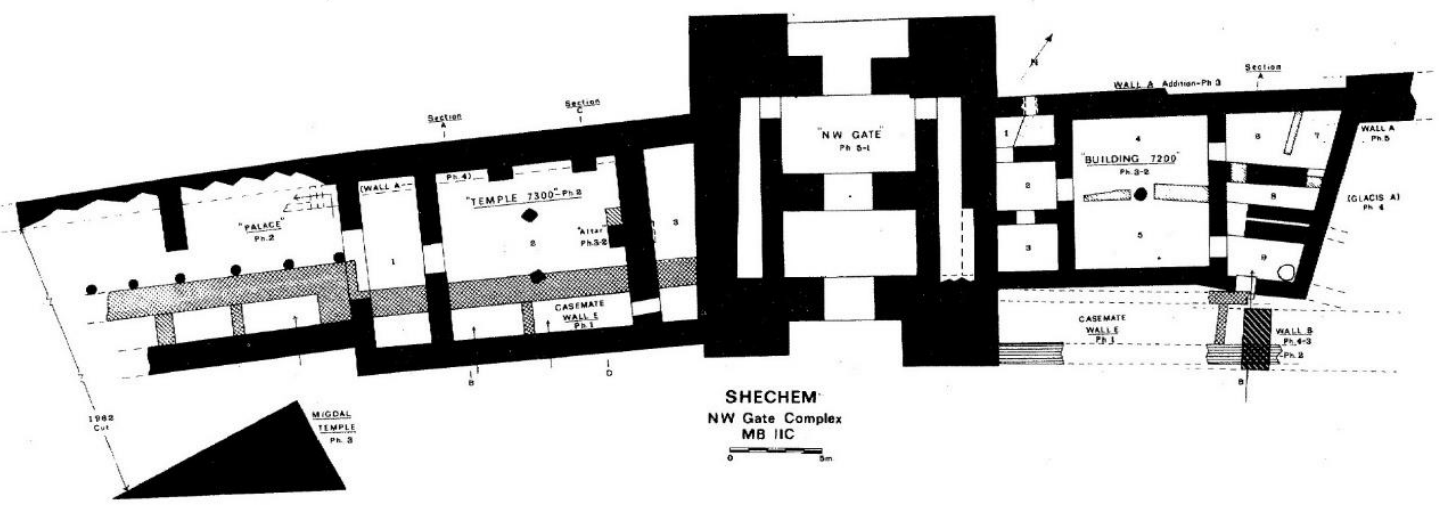

Figure 6. Casemate Wall E, part of Field IV at Shechem (from Dever 1974: 32). 
reused their MB fortifications into the early LB (Kempinski 1992b: 136-38). Other sites show an obvious weakening of their fortifications due to either decline or neglect with little evidence of repair attempts. Some cities, even major sites like Tel Lachish, may even have been unfortified throughout the LB.

A few casemate wall systems continued to be used into the beginning of LBI only to disappear shortly thereafter, like those at Hazor and Ta'annek (Kempinski 1992b: 136; Lapp, P. 1969: 18). Meanwhile in Transjordan, Tall Zira'a provides an example of a casemate wall system that was built during the LB. This casemate (Figure 7) was discovered in Stratum IV of Area 1 dating to 1450-1300 B.C. (Haser 2007: 528). Khirbat al-Lahun (Figure 8) was originally dated to the LB. After a reexamination of the pottery and material finds, it is now being dated to the transitional LB-early Iron Age period. It is believed to have been built no earlier than the late $12^{\text {th }}$ century B.C. (van der Steen 1996: 55; Routledge 2000: 47). This site will be covered in more detail in the third chapter.

\section{Casemate Wall Systems and Siege Warfare}

The defensive system around Boğazköy is often considered "the culmination of the art of fortification in the Late Bronze Age" (Kern 1999: 14-15). A close look at the way the settlement's defenses worked together support this conclusion. The defenses at Boğazköy included: the use of circular walls to combat undermining, a lower wall protecting the main casemate-style wall, underground posterns along the underside of the walls on their strongest side for staging surprise sorties or used as escape routes, interior walls so that enemies could only access a portion of the settlement if they managed to breach the walls, and an inner citadel which offered a last line of defense. Each of these systems were built to cover for the other's weaknesses. Paul Kern believes that the 


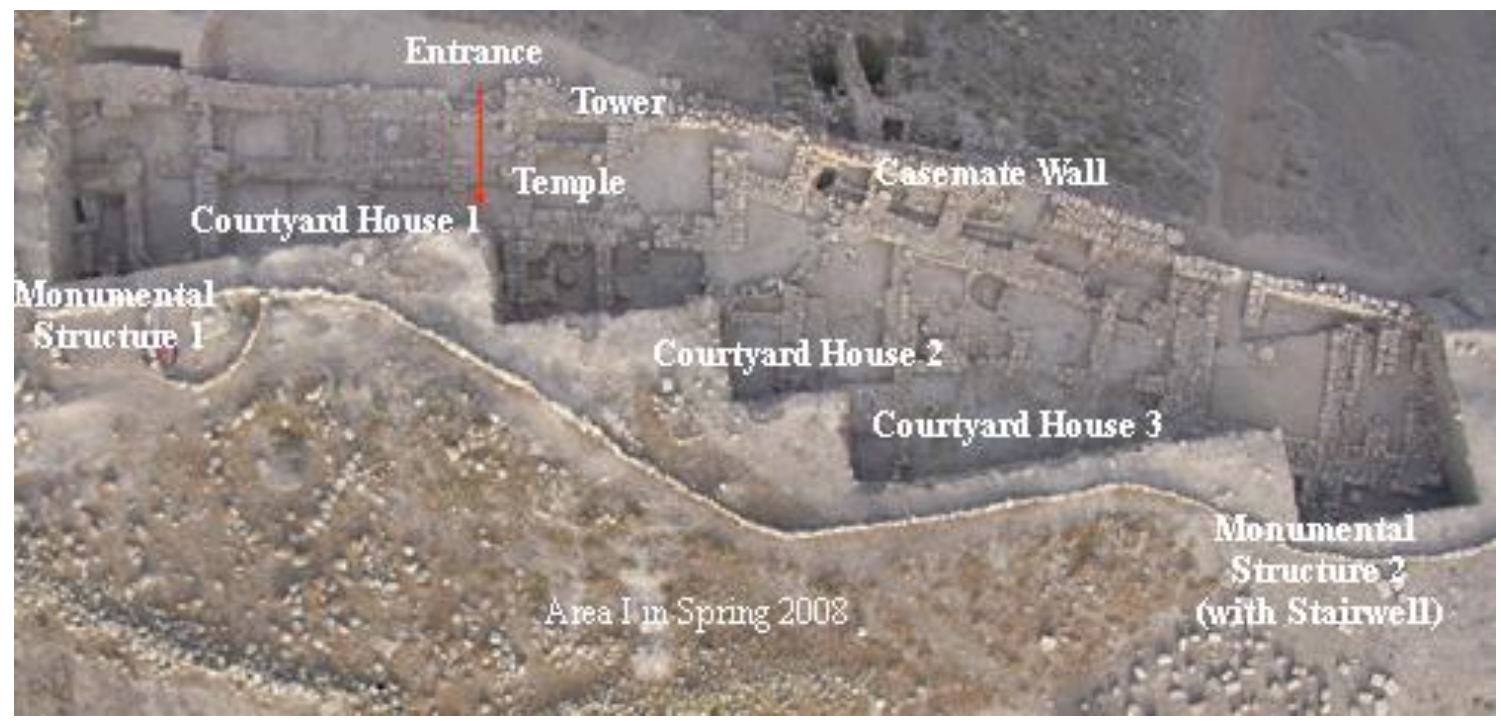

Figure 7. Casemate wall system in Area 1 at Zira'a (modified from Haser 2007: 152).

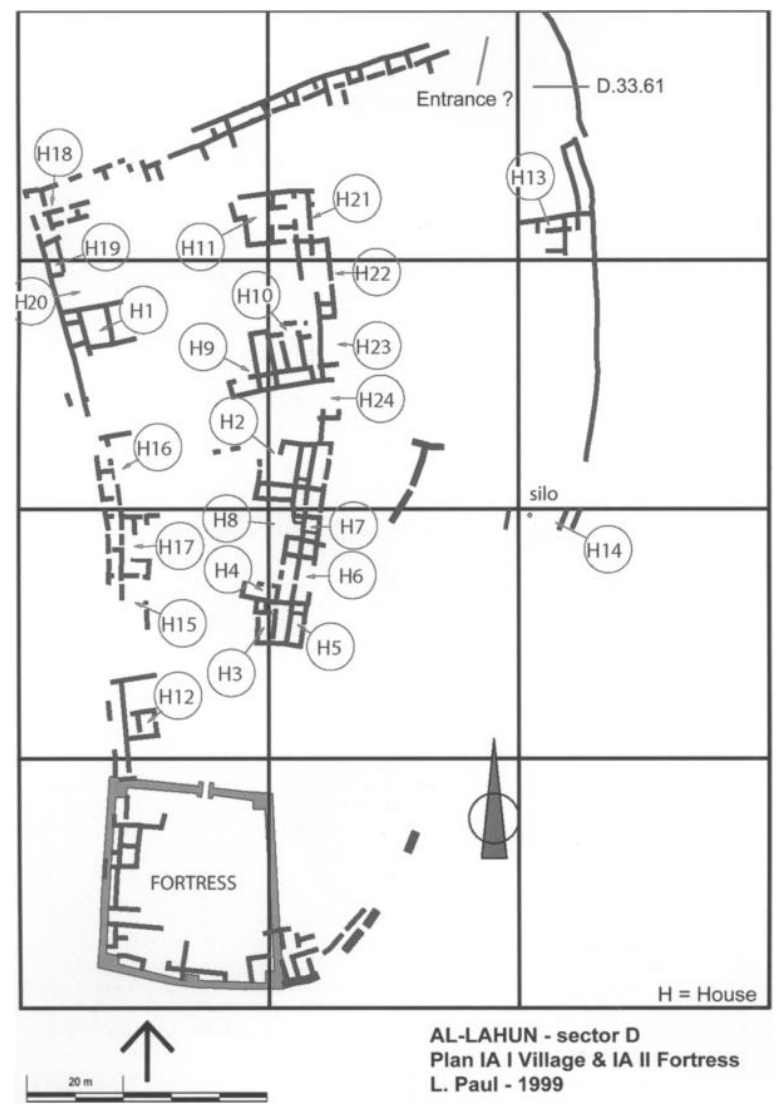

Figure 8. Casemate wall system on north, west, and south side of Iron I settlement at Kh. al-Lahun (from Swinnen 2009: 32). 
complexity of these fortifications was the result of a powerful motive, possibly the threat of battering rams (Kern 1999: 14-15).

The existence of this potential threat is supported by the wall painting at Beni Hasan (dating to the $20^{\text {th }}$ century B.C.) which depicts three men protected within a mobile structure while using a long beam, possibly with a metal point, to batter at the wall (Figure 9). While primitive, the painter was impressed enough to portray this battering ram as a main weapon in this siege. However, Paul Kern argues they these primitive battering rams were most likely "little more than picks with which the symbolic creatures are hacking at the wall (Kern 1999: 16).

In the $18^{\text {th }}$ century B.C., the Mari letters provide a description of improvements to the battering ram which was made largely of wood. Ishme-Dagan wrote, "Thus saith Ishme-Dagan, thy brother! 'After I conquered [the names of three cities], I turned and laid siege to Hurara. I set against it the siege towers and battering-rams and in seven days

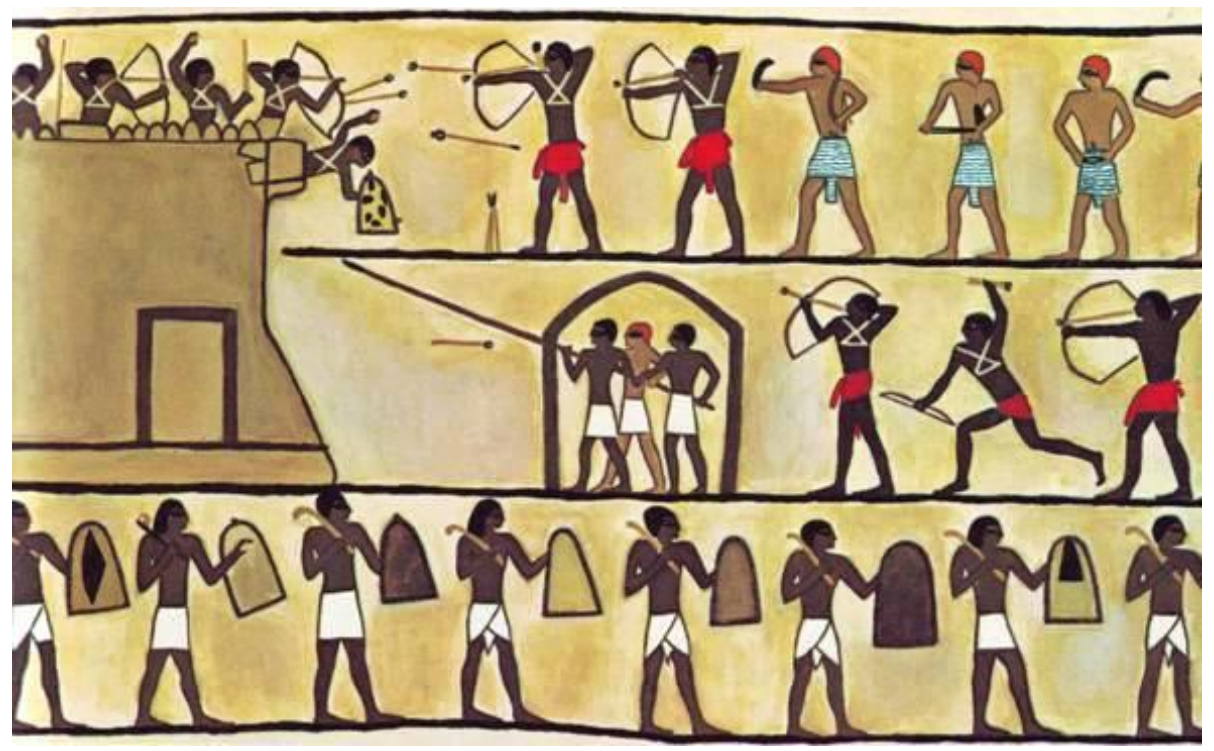

Figure 9. A primitive battering ram depicted on a wall painting from Beni-Hasan (modified from Kern 2004: 40). 
I vanquished it. Be pleased!"' (Yadin 1963: 70). Starting in the $18^{\text {th }}$ century B.C., the way that battering rams were built and operated was unlikely to have changed for nearly one thousand years until an improvement was made by the Assyrians (Eph'al 2009: 82-3).

Egyptian reliefs and written documents from 1570-1200 B.C. do not show or mention the battering ram (Seevers 2013: 136). This apparent absence of battering rams in Egypt during the New Kingdom may be due to several factors. First, it is possible that the distance between Egypt and Canaan was too great to be worth transporting such heavy equipment. Fortifications at this time had also been built to withstand these very weapons. Battering rams were still not as powerful as they would later become and current fortifications had effectively, if not temporarily, rendered this more primitive ram obsolete.

Dating to around 1500 B.C., a Hittite document describes siege warfare in Anatolia with the use of a battering ram and describes how it was built and operated.

They broke the battering ram. The King waxed wroth and his face was grim: "They constantly bring me evil tidings.... Make a battering-ram in the Hurrian manner! and let it be brought into place. Make a 'mountain' and let it [also] be set in its place. Hew a great battering-ram from the mountains of Hazzu and let it be brought into place. Begin to heap up earth...." The king was angered and said: "Watch the roads; observe who enters the city and who leaves the city. No one is to go out from the city to the enemy...." They answered: "We watch. Eighty chariots and eight armies surround the city" (Yadin 1963: 70-71).

This describes the existence of two types of battering rams: the one that broke and the one built in the "Hurrian manner." Neither battering ram would have been as powerful as those used by the Assyrians (Figure 10 and 11) in the ninth century B.C. or otherwise the casemate walls built by the Hittites would not have survived similar attacks (Kern 1999: 19). We would have most likely seen a move away from casemate wall systems instead of towards them had the battering rams been more powerful during this time. Rather, it 


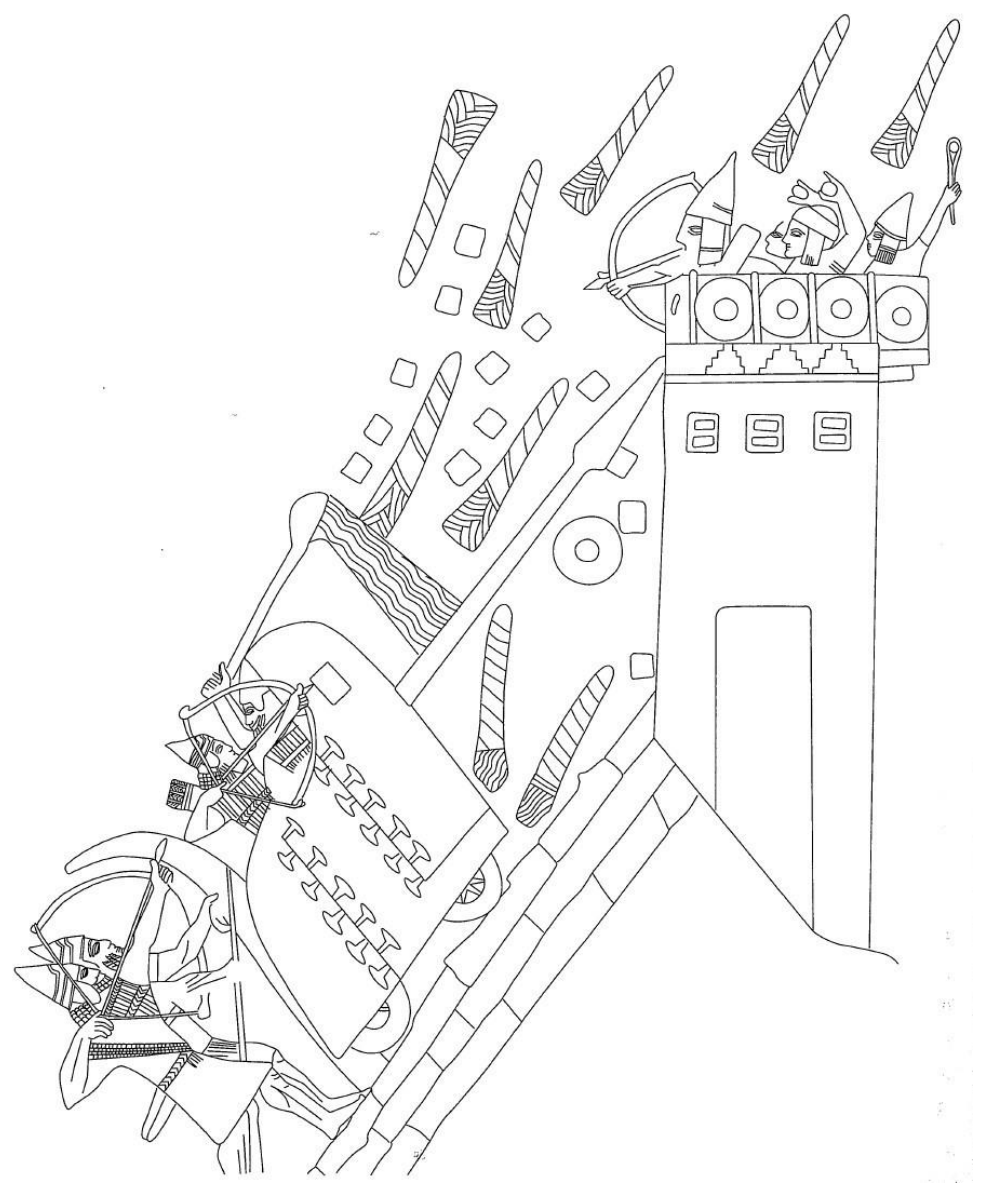

Figure 10. Assyrian siege engine attacking Lachish (from Yadin 1963: 70).

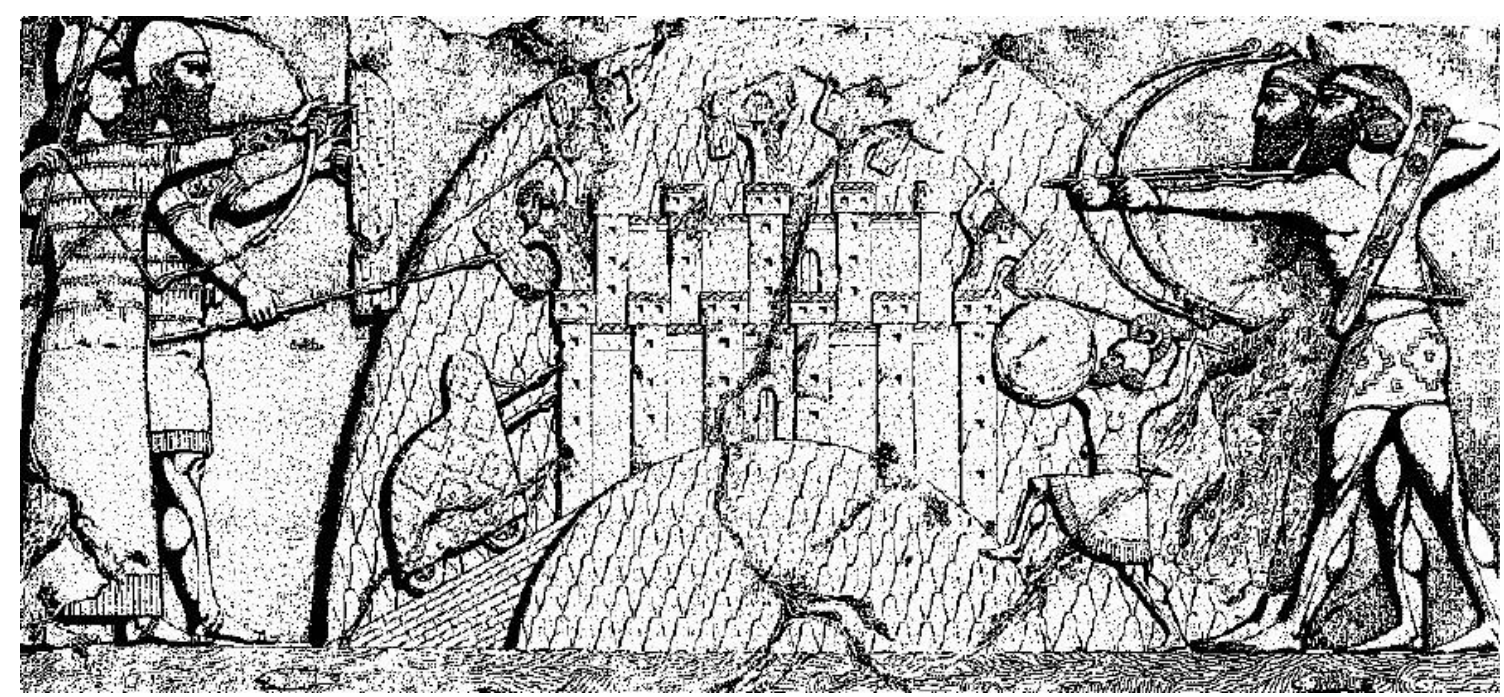

Figure 11. An Assyrian attack on a city with a battering ram (Eph'al 2009: 91. 
appears as though the various fortifications used in the defense of Boğazköy during the MB including the casemate wall system "were designed primarily to prevent breaching by the battering-ram" (Yadin 1963: 71).

Second Samuel 20:15 says that the Hebrews "were battering the wall to throw it down" during the time of Joab. However, the Hebrew word translated as "battering" may be more literally translated as "ruining." If this is a description of the use of an actual battering ram, they were likely to be more similar to the primitive battering ram depicted at Beni-hasan rather than those used by the Assyrians two hundred years after the time of Joab (Kern 1999: 37). The Hebrews would likely have built stronger walls had they, themselves had access to such advanced battering rams as the Assyrians.

There is an obvious abandonment of the use of casemate wall systems in favor of solid walls in the post-Solomonic period. This suggests that the advantages of casemate walls (storage, living space, quick and easy to build) no longer outweighed the disadvantage of it being weaker than solid walls. There was a large-scale switch from casemate-style walls to solid, massive walls in the ninth century B.C. This occurred at the same time as the resurgence of the Assyrians and their powerful battering rams, suggesting that this shift "was a classic example of a defensive reaction to a new offensive threat" (Kern 1999: 40). 


\section{CHAPTER 3}

\section{THE CASEMATE WALL SYSTEM OF KHIRBAT SAFRA}

\section{Introduction to Khirbat Safra}

Khirbat Safra is a triangular-shaped site covering an area of approximately 2.6 acres. It is located on the western side of Wadi er-Rishshah, a northern tributary to Wadi Zarqa Main and is about $17 \mathrm{~km}$ southwest of Madaba (Figure 12). Excavations occurred during the 2018 and 2019 seasons under the direction of Paul Gregor, Constance Gane, and Paul Ray of the Institute of Archaeology at Andrews University. Four excavation fields (A-D) were opened in 2018 with continued excavation in two fields (B and D) in 2019. Excavation fields and squares were "laid out using GPS on the basis of a grid of 6.0 x 6.0 m squares, placed over a topographic map (Figure 13) created by the Department of Antiquities surveyors in 2017, with the tops of some partly-exposed architecture also serving as fruitful locations for their initial placement" (Figure 14; Gregor et al. 2018:1).

\section{Casemate Wall System in Field A}

Field A (Figure 15) was excavated in 2018 under the supervision of Constance Gane. Squares A1 and A3 were opened on the western edge of the site. Part of Kh. Safra's casemate wall system was uncovered in Square A1 while Square A3 revealed two rooms built along the eastern side of the inner casemate wall. Parts of both Square 1 and 

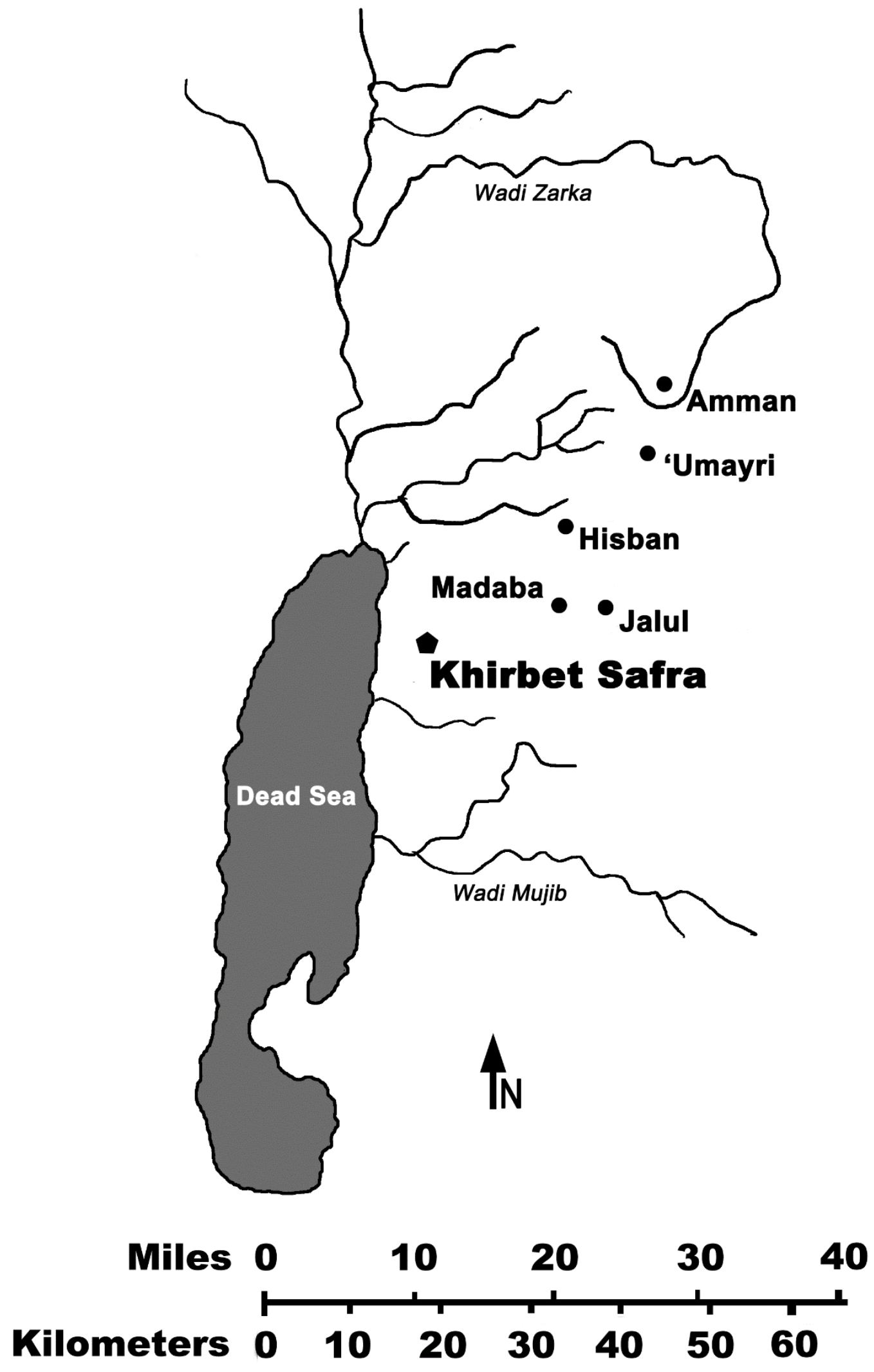

Figure 12. Location of Kh. Safra (Gregor, Ray, and Moody: fig. 1). 


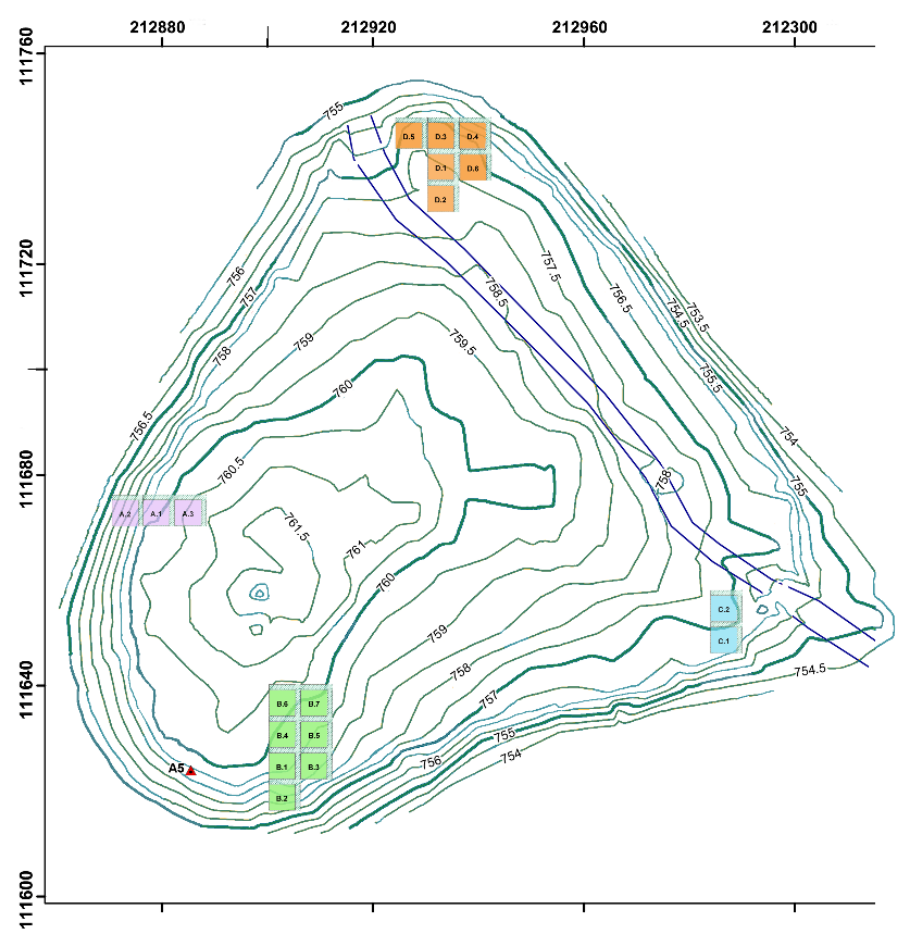

Figure 13. Topographic map of Kh. Safra with excavation fields (Gregor, Ray, and Moody: fig. 2).

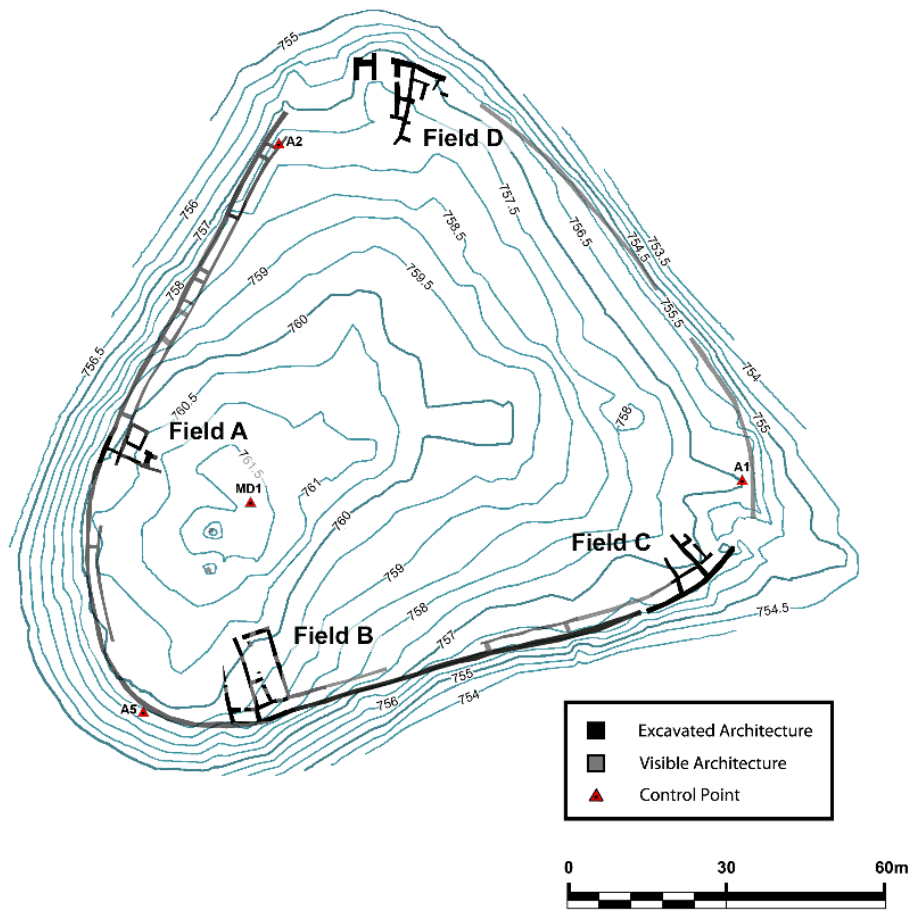

Figure 14. The casemate wall system of Kh. Safra (Gregor, Ray, and Moody: fig. 3). 


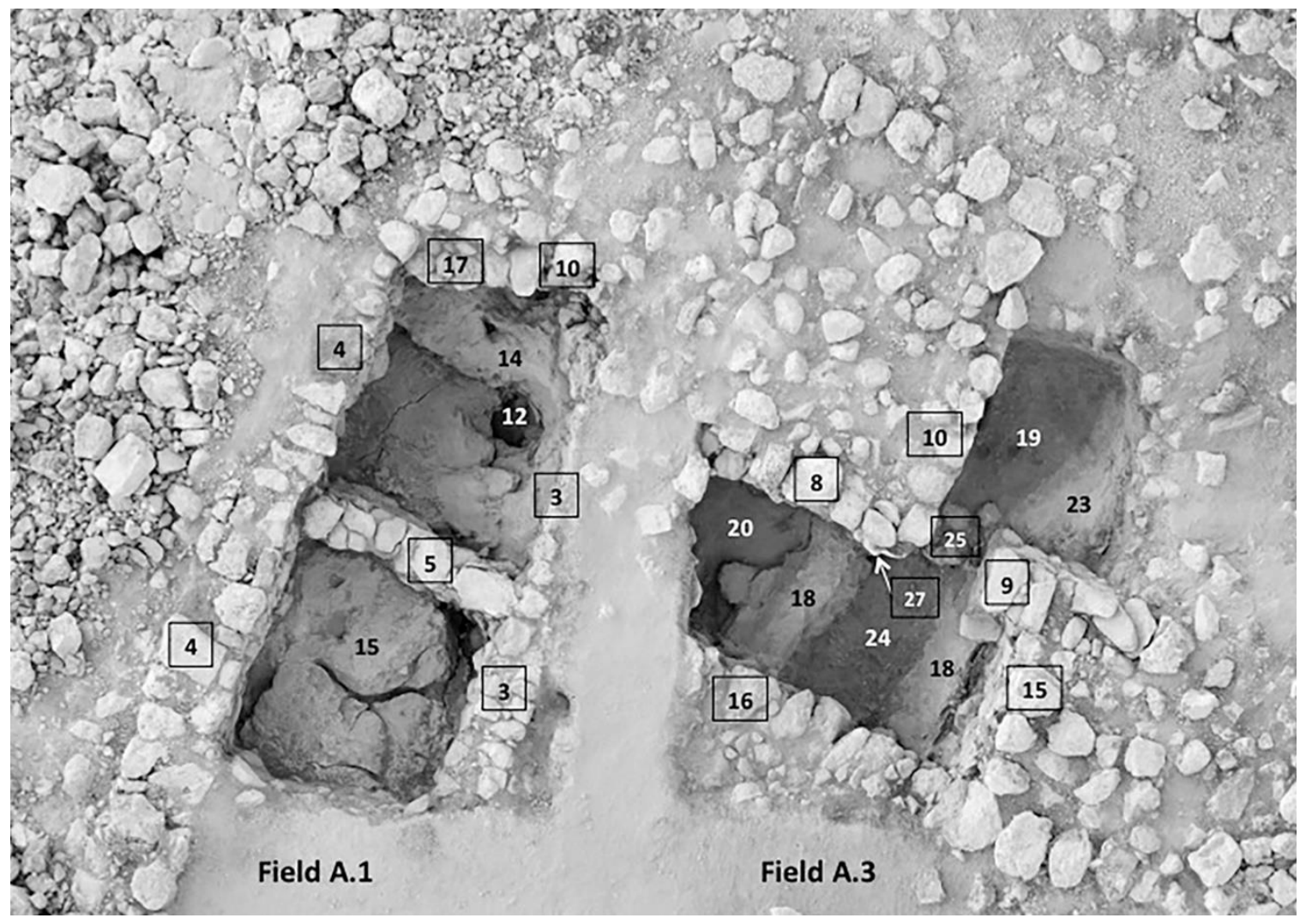

Figure 15. Kh. Safra Field A (Gregor et al. 2018: fig. 4).

Square 3 were excavated down to bedrock. The direct relationship between Square 3 and the casemate wall system is currently unclear, however architecture visible from the surface seems to suggest that the inner casemate wall in Square 1 is also serves as the western wall of the southern room in Square 3. Both squares will be discussed further, below.

\section{Field A Square 1 - Casemate Wall System}

Square A1 revealed two rooms between an inner (A1.3) and outer (A1.4) casemate wall (running north/south), separated by a transverse wall (A1.5) with another transverse wall (A1.10) along the balk to the north (both running east/west). Each wall is 
primarily composed of unhewn limestone and chert and constructed in the boulder \& chink style. The inner casemate wall (A1.3) has one row with a width between 0.6 and $0.65 \mathrm{~m}$ and between four and five courses with a height between 0.95 and $1.5 \mathrm{~m}$ (Safra Excavation Archives). The outer wall (A1.4) consists of two rows with a width between 0.95 and $1.0 \mathrm{~m}$ and seven courses with a height between 0.95 and $1.55 \mathrm{~m}$ (Safra Excavation Archives). The transverse wall (A1.5) consists of one row with a width of $0.60 \mathrm{~m}$ and four to six courses with a height of $1.4 \mathrm{~m}$ (Safra Excavation Archives). The transverse wall (A1.10) exhibits two rows with a width of $0.95 \mathrm{~m}$ and six courses with a height between 1.1 and $1.3 \mathrm{~m}$ (Safra Excavation Archives).

These casemate walls were built directly on the bedrock (A1.14-15) with a redbricky material (A1.16) used to fill in the bedrock's natural crevices. This may have been the first occupation layer as early Iron Age I ceramics were found lying directly on the bedrock (Gregor et al. 2018: 3). Early Iron Age I ceramics, stone grinders and pestles, and animal bones were discovered between the bedrock and a beaten-earth surface (A1.9, 11) in both the northern and southern casemate rooms (Safra Excavation Archives). The pottery remains above this surface were a mix of Iron Age I, Iron Age II and Byzantineperiod (Safra Excavation Archives). There was also evidence in this layer of "mudbrick superstructure collapse, indicating a violent disruption of occupation" (Gregor et al. 2018: 3).

\section{Field A Square 3}

Square A3 (along the east side of the inner casemate wall) consists of a northern and southern room connected with a doorway (A3.25). Consistent with Square A1, early Iron Age I pottery and red-bricky material $(\mathrm{A} 3.21,24)$ was found between the bedrock 
$(A 3.18,23)$ and a surface, in this case a plastered floor (A3.21). Early Iron Age I ceramics were found imbedded in the plaster and covered with a thick layer of ash (up to $0.50 \mathrm{~cm})$ in the southern room. Debris found between this layer of ash (A3.20) and a Byzantine beaten earth surface (A3.17) suggest a time of abandonment. Walls dating to the Byzantine period (A3.8-10;15-16) with another beaten earth surface (A3.11) indicate a "relatively well-established Byzantine-period occupation on this part of the site" (Gregor et al. 2018: 4).

\section{Casemate Wall System in Field B}

Field B (Figure 16) was excavated in the 2018 and 2019 seasons under the supervision of Paul Ray. Three squares (B1-3) were opened in 2018 and four squares (B4-7) were opened in 2019 on the southwestern edge of the site. Square B1 was completely excavated in 2018. Square B2 was not excavated but was used to trace the outer casemate wall. Square B3 was partly excavated in 2018 and completed in 2019. Squares B4-6 were completely excavated in 2019 and B7 was opened in 2019 but was uncompleted. These seven squares consisted of two broad rooms between the outer and inner casemate walls which were separated by transverse walls with "parts of two buildings, consisting of long room-structures, sharing one wall, and connected with the broad-room casemates previously excavated" (Gregor, Ray, and Moody 2019: 3).

Field B Squares 1 and 3 - Casemate Wall System

The casemate wall system in Field B was excavated solely in Squares B1 and B3 (B2 was unexcavated but the outer casemate wall which was visible on the surface was assigned a locus, Locus 1). The casemate wall system is composed of two broad rooms 


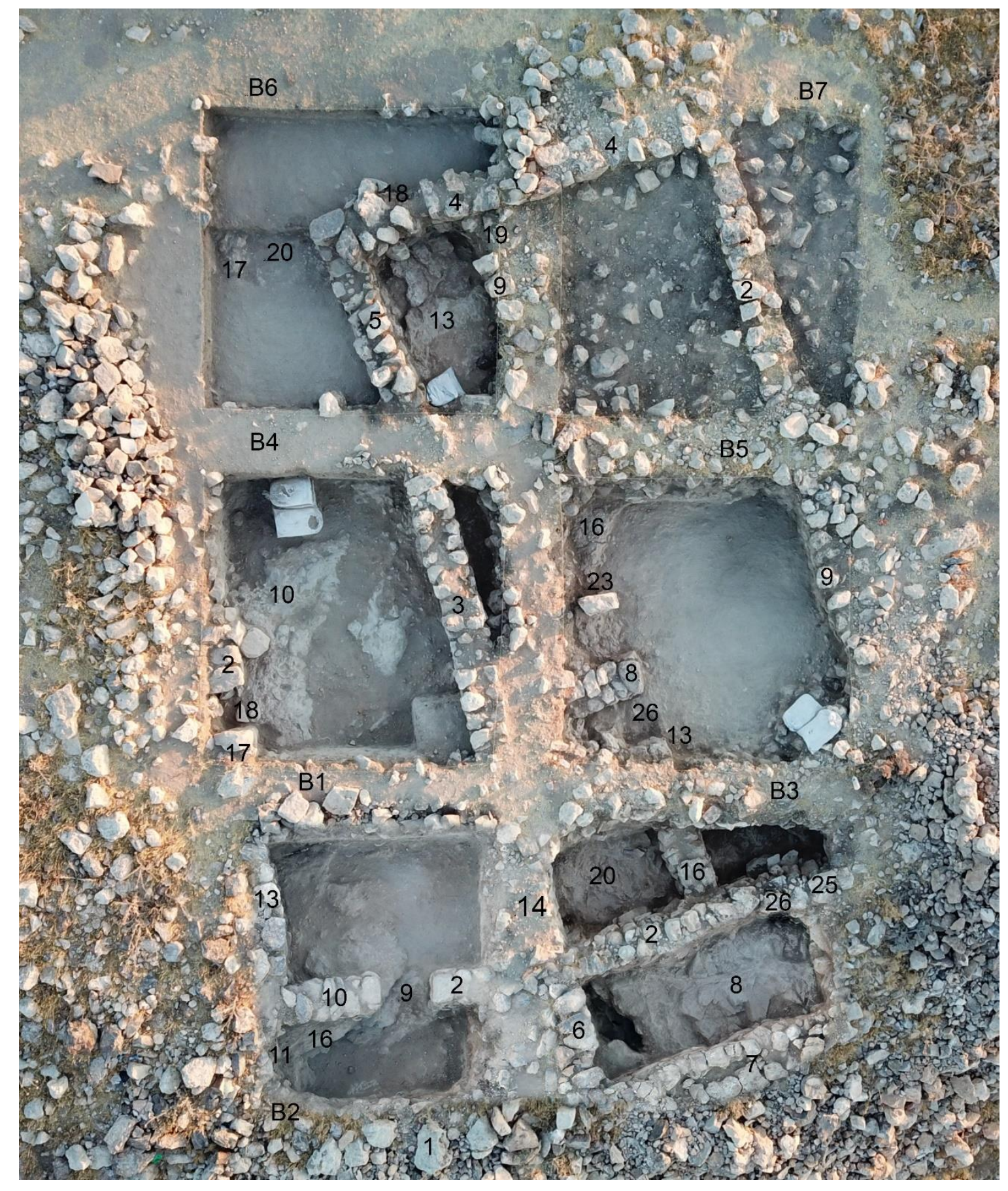

Figure 16. Kh. Safra Field B (Gregor, Ray, and Moody: fig. 5). 
(one in Square B1 and one in Square B3) between an inner (B1.2, 10=B3.2, 25) and outer (B2.1=B3.7) casemate wall (running east/west) with two transverse walls (B1.11; B3.6; running north/south) along the western balks of their respective squares. Each wall is primarily composed of unhewn limestone and chert and constructed in the boulder \& chink style. The inner casemate wall consists of one row with a width between 0.5 and $0.8 \mathrm{~m}$ and between four and seven courses with a height between 0.9 and $1.4 \mathrm{~m}$ (Safra Excavation Archives). The outer wall exhibits two rows with a width between 1.0 and 1.1 $\mathrm{m}$ and four to six courses with a height between 1.3 and $1.4 \mathrm{~m}$ (Safra Excavation Archives). The transverse wall (B1.11) is partially imbedded in the western balk with one row (the width of which is yet, unknown) and three to five courses with a height between 1.0 and $1.1 \mathrm{~m}$ (Safra Excavation Archives). The transverse wall (B3.6) is one row with a width between 0.55 and $0.6 \mathrm{~m}$ and four to six courses with a height between 1.6 and 1.8 m (Safra Excavation Archives).

Excavations discovered that the two-row outer wall (B3.7) was first built directly on bedrock (B3.8) in preparation for occupation. The one-row inner wall $(\mathrm{B} 1.2,10=\mathrm{B} 3.2$, 25) and cross walls (B1.11; B3.6) were added once the crevices in the bedrock (B1.16=B3.8) were filled with a hard, red-bricky, material (unexcavated in Square 1; B3.5), much like what was found in Field A. A doorway with stone thresholds (B1.9) was excavated in Square B1 leading from the casemate room through the inner casemate wall $(B 1.2,10)$ and into Building 1, which was further uncovered in Squares B4 and B6. Another doorway (B3.26) was found but unexcavated in Square B3, which led from the casemate to Building 2. The thresholds in Square B1, "connected with both beaten-earth surfaces... to keep everything level on both sides of the wall" (Gregor et al. 2018: 4). 
A destruction layer occurred during the early Iron Age II (B1.12; B3.5) by what was most likely an earthquake causing wall collapse (Figure 17). There seems to be a period of abandonment after this with possible late Iron Age II (evidenced by ceramics) and Byzantine squatter activities (B3.12-13).

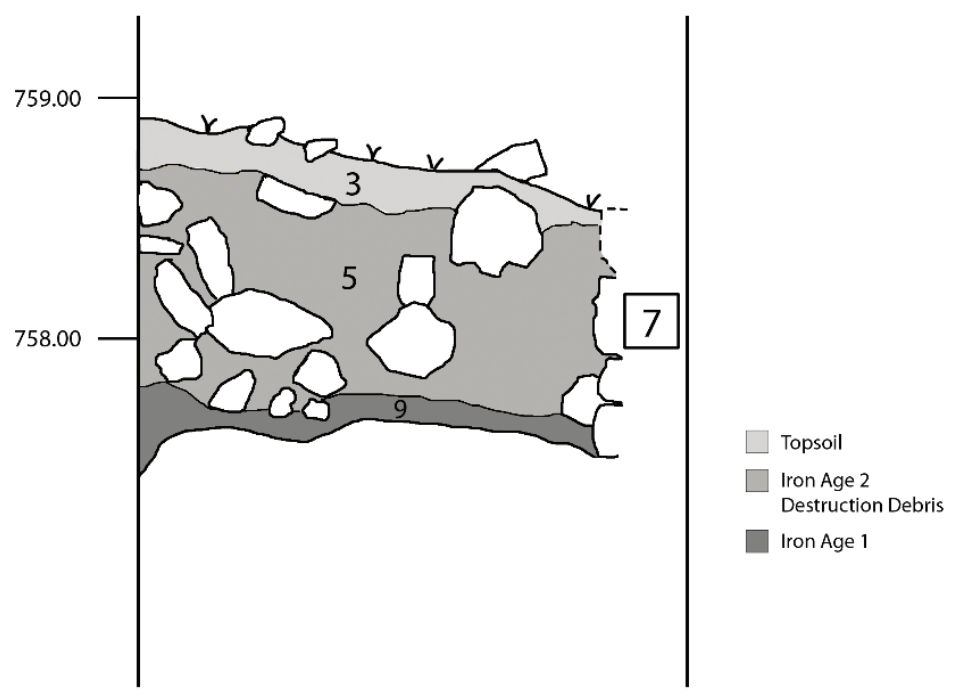

Figure 17. Kh. Safra Field B3 east balk (Gregor et al. 2018: fig. 6).

Field B Squares 1-6 - Buildings 1 and 2

Building 1 (the western structure) can be traced from Square B1 through Square B4 and into Square B6. This building's western wall can be traced through Square B1 and some of Square B4 but disappears into the west balk of Square B4, just beyond what appears to be a western entrance to the building. The northern wall of Building 1 is represented by what "appears to be the bedrock footing (B6.17) to a ghost wall, on its western end, again disappearing in the balk" (Gregor, Ray, and Moody 2019: 3). The eastern wall of Building 1 is shared with Building 2. Building 2 can be outlined through 
Squares B3-7. Each wall is completely exposed except for portions still within the unexcavated balks (B3.6, 14=B4.3=B6.5; B5.9=B7.2). The northwest corner of the northern wall has an entrance was excavated (B6.18) with a small room (B5.8, 13=B3.16) on the building's southwestern side which subdivided the building with a doorway (B5.26) into the main room on the eastern side. North of this room excavators discovered a pillar (B5.23) siting directly on bedrock (B5.16), a short section of a wall (B6.9) that disappears into the balk, and another entrance (B6.19). How these elements are related are, as of yet, unknown and require further excavation.

Several beaten-earth surfaces were uncovered in Buildings 1 and 2. Above the red-bricky fill material (B1.15; B3.11) used to fill in the crevices of the bedrock (B1.16=17=B3.8) is the first occupation layer (Building 1, B4.16, 19, 21 and B6.12, 21; Building 2, B3.23, B5.25) with two beaten-earth surfaces (Building 1, B1.5=B4.12 and B6.10; Building 2, B3.21 B5.19=20, 21) laid throughout Iron Age I (B1.5=B4.12). A destruction by a conflagration (B5.22) is evident in Building 2 between these two occupational layers but is not seen in Building 1. Another beaten-earth surface (B1.6=B4.7) was above a fill layer (Building 1, B1.7=B4.11; Building 2, B5.24), possibly laid during the early Iron Age II. Afterwards, a possible earthquake left this area abandoned (evidenced by considerable ruins) with possible later squatter activities and post-abandonment earth material (B1.1, 3; B3.1, 2) collecting since.

\section{Casemate Wall System in Field C}

Field C (Figure 18) was supervised by Trisha Broy and is in the southeastern corner of the site. Two squares ( $\mathrm{C} 1$ and $\mathrm{C} 2)$ were opened in 2018. Part of the site's casemate wall system was found in Square C1 with parts of several rooms built along the 


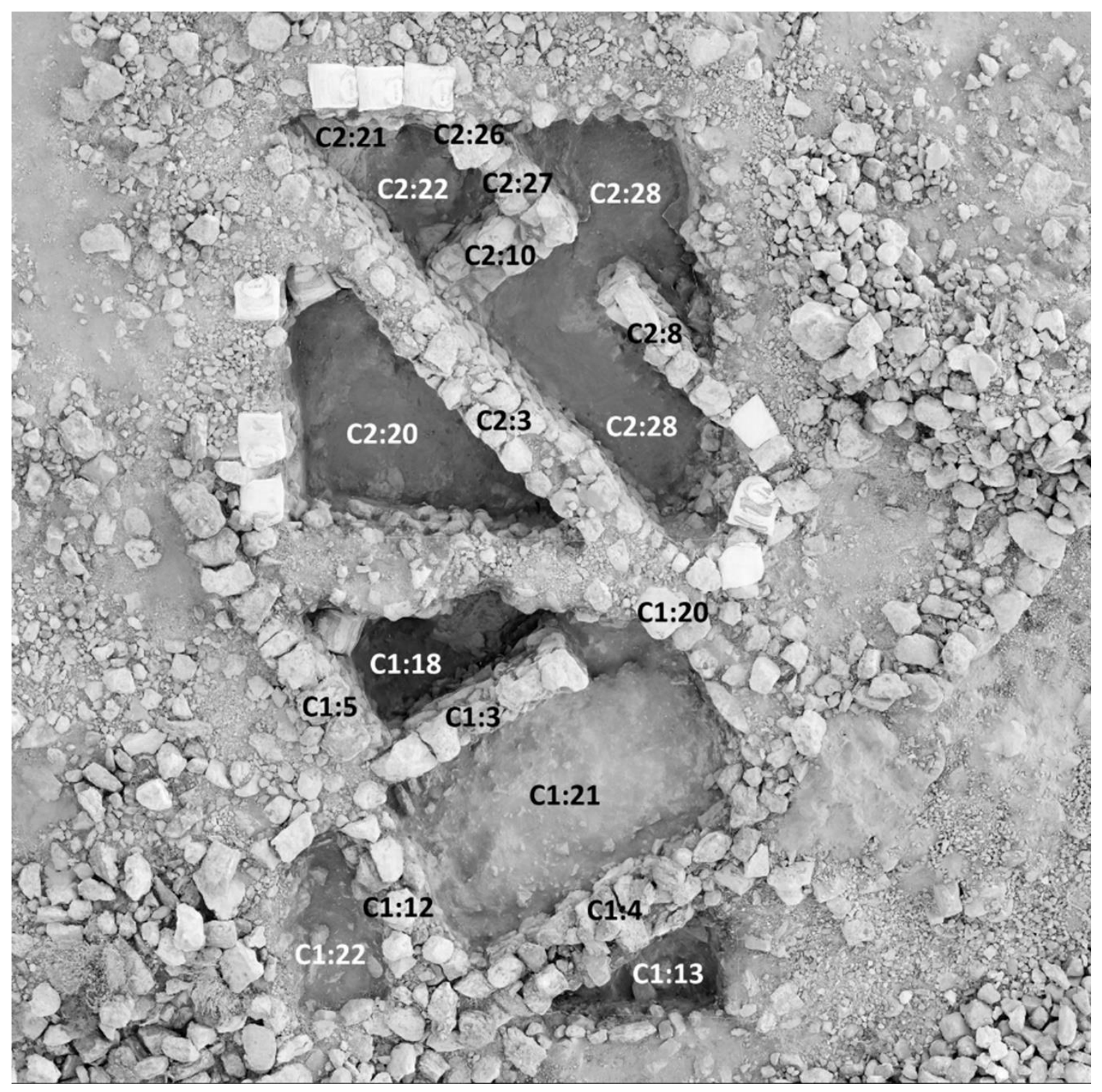

Figure 18. Kh. Safra Field C (Gregor et al. 2018: fig. 7). 
northern side of the inner casemate wall excavated in Squares C1 and C2. The direct relationship between the casemate wall system and the rooms to the north is currently unclear but evidence of a doorway leading out of the casemate room indicates that there is a relationship. This field has a roughly similar architectural layout to what was found in Field B.

\section{Field C Square 1 - Casemate Wall System}

Square $\mathrm{C} 1$ revealed one full casemate room and part of another room between an inner (C1.3) and outer (C1.4) casemate wall (running east/west), separated by a transverse wall $(\mathrm{C} 1.12)$ with another transverse wall $(\mathrm{C} 1.20)$ along the eastern balk (both running north/south). Less is known about the casemate wall system in Field C compared to Fields A and B because neither of the casemate rooms were excavated down to bedrock. Each wall was primarily composed of unhewn limestone and chert and constructed in the boulder \& chink style. The inner casemate wall $(\mathrm{C} 1.3)$ consists of one row with an unknown width, unknown number of courses, and unknown height (Safra Excavation Archives). The outer wall (C1.4) yielded two rows with a width between 0.9 and $1.0 \mathrm{~m}$, an unknown number of courses, and unknown height (Safra Excavation Archives). The transverse wall (C1.12) is one row with an unknown width, unknown number of courses, and unknown height (Safra Excavation Archives). The transverse wall (C1.20) has an unknown number of rows with an unknown width, unknown number of courses, and unknown height (Safra Excavation Archives). Phasing within the casemate wall system is unclear with predominantly Iron Age I but some Iron Age II pottery found along with a slingstone (Safra Excavation Archives). 
A small area located outside the outer casemate wall was excavated down to bedrock as part of Square C1 (Safra Excavation Archives). Above the bedrock was more of the red-bricky material which indicates that the casemate wall system in Field $\mathrm{C}$ was built in much the same manner as in Fields A and B. These casemate walls were built directly on the bedrock and the largely sterile red-bricky material used to fill in crevices (Safra Excavation Archives). Soil above this material was also fairly sterile with a small amount of Iron Age II pottery found (Safra Excavation Archives).

The north-western corner of Square C1 is part of a room that was further exposed in Square C2. The findings from this room will be discussed in the following section.

Field C Square 1 and 2 - Rooms North of Casemate Wall System

Multiple rooms were excavated north of the inner casemate wall and the phasing remained consistent in each. A continuation of what we have seen in every other field, a red-bricky material $(\mathrm{C} 1.17 ; \mathrm{C} 2.17,25)$ was used to flatten the bedrock $(\mathrm{C} 1.18 ; \mathrm{C} 2.20,22$, 28), and LBII/early Iron Age I transitional pottery found on top of this material indicates it was used as a surface (Safra Excavation Archives). A $0.10 \mathrm{~m}$ thick destruction layer $(\mathrm{C} 1.16 ; \mathrm{C} 2.16,18,23-24)$ sealed this material and contained several broken ceramic vessels dating to the Iron Age I or earlier and many objects used in domestic food preparation (Figure 19).

A beaten earth floor created a second occupational level above this destruction layer (Safra Excavation Archives). The entrance $(\mathrm{C} 1.19=23)$ which leads from the larger of the two casemate rooms, through the inner casemate wall, and into a large room, was blocked during this time. A second entrance (C2.27) was blocked in the northwest corner of Square C2 which connects a small room with a possible staircase (C2.21). The surface 


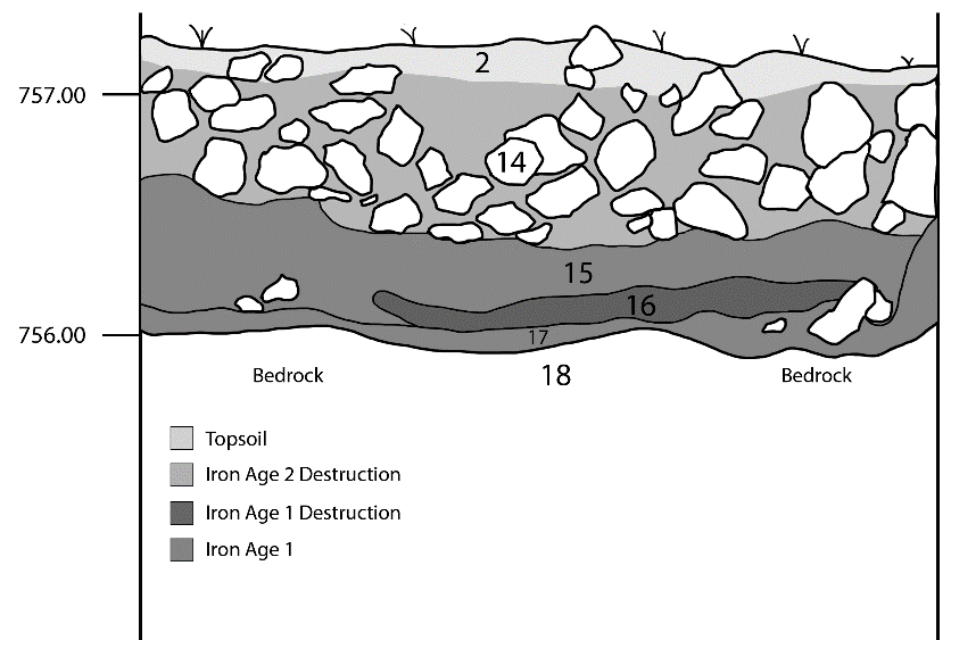

Figure 19. Kh. Safra Field C1 north balk (Gregor et al. 2018: fig. 8).

in this small room contained a roof-roller, a pair of bronze bangles, and predominantly early Iron Age I and Iron Age I flat-lying pottery sherds (Safra Excavation Archives). A series of ash layers were discovered above this occupational layer (C1.9-11, 14; C2.4-6, 9) indicating a second conflagration with ceramics dating to the Iron Age II (also evident in the casemate rooms). There was then a period of abandonment $(\mathrm{C} 1.1-2,6-8 ; \mathrm{C} 2.1-2,7)$ with a few scattered Iron Age II ceramics and a significant amount of wall tumble (Gregor et al. 2018: 5-6).

\section{Casemate Wall System in Field D}

Field D (Figure 20), excavated in the 2018 and 2019 seasons, is on the northernmost edge of Kh. Safra and was supervised by Jacob Moody. Three squares were opened in 2018 (D1-3) while only D1 and D2 were fully excavated that year. Excavation in D3 was completed and three new squares were opened and excavated (D4-6) in 2019. Wall lines were visible on the surface and guided the placement of these squares in an attempt to better understand the architecture (specifically the reasoning behind the 


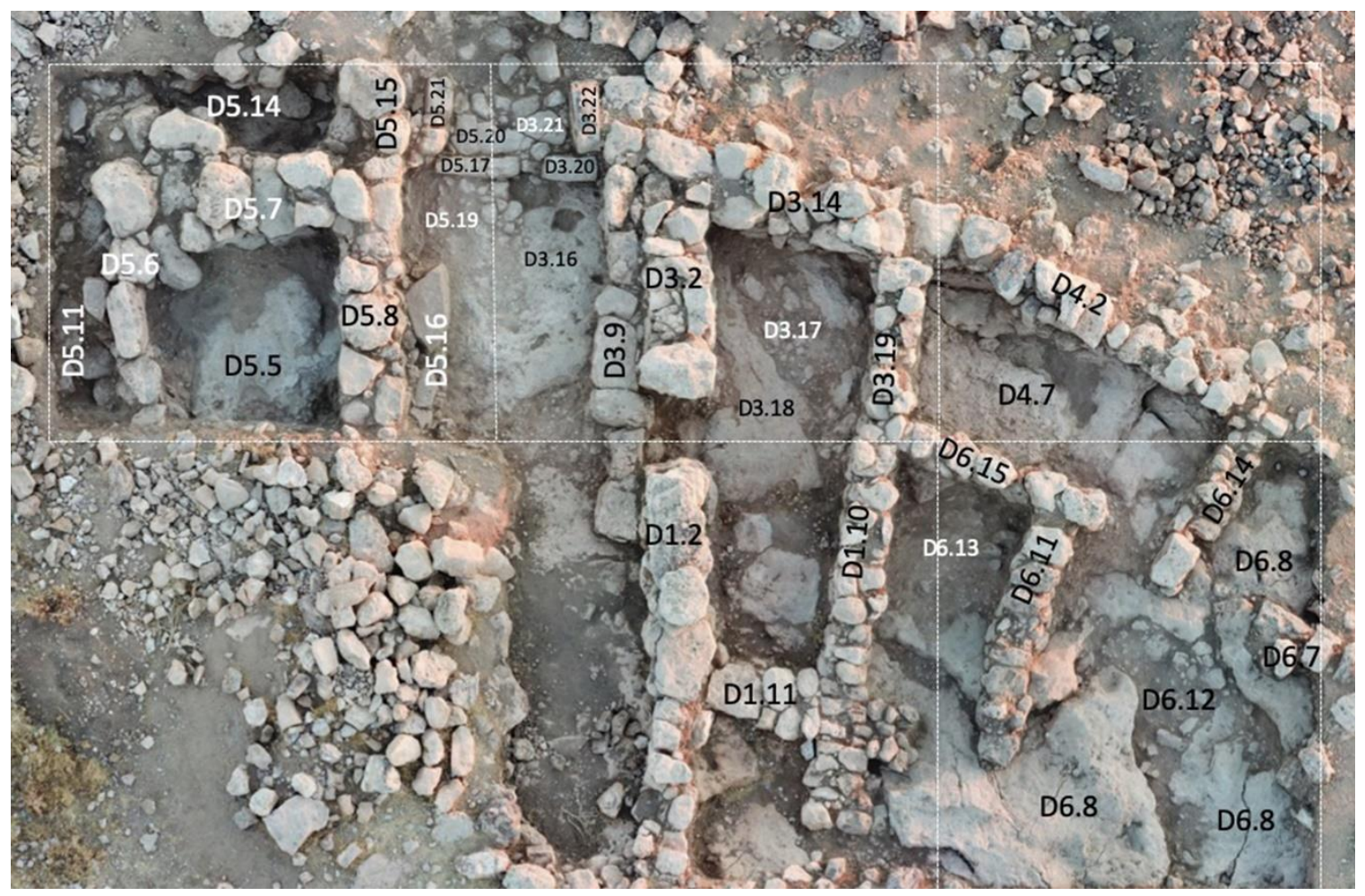

Figure 20. Kh. Safra Field D (Gregor, Ray, and Moody: fig. 7).

use of such large wall stones) and to excavate between the casemate walls (Gregor et al. 2018: 6; Gregor, Ray, and Moody 2019: 5). The earth matrix in Field D is extremely shallow, only $0.10 \mathrm{~m}$ deep in some places, making it easy for each square to reach bedrock. Balks were removed in certain places which provided a clearer picture of the architectural details, but sections in Squares D3 and D4 were left unexcavated since they were located outside the outer casemate wall. These six squares revealed one casemate room (and part of another), part of a gate complex, and several interior rooms.

Field D Squares 3, 4, and 6-Casemate Wall System

In Squares D3, D4, and D6 one complete casemate room and the southwestern corner of another room were uncovered between an inner (D6.7, 15) and outer 
(D3.14=D4.2=D5.7) casemate wall (running east/west), separated by a transverse wall (D6.14) with another transverse wall (D3.19), excavated in the eastern balk of Square D3 (both running north/south). Each wall was primarily composed of unhewn limestone and chert and constructed in the boulder and chink style. The inner casemate wall (D6.7, 15) consisted of one row with an unknown width, unknown number of courses, and unknown height (Safra Excavation Archives). The outer wall (D3.14=D4.2=D5.7) consisted of one to two rows with a width of $0.8 \mathrm{~m}$ and two courses with a height between 0.65 and 0.85 m (Safra Excavation Archives). The transverse wall (D6.14) exhibits one row with an unknown width, unknown number of courses, and unknown height (Safra Excavation Archives). The transverse wall (D3.19) is also one row with an unknown width, unknown number of courses, and unknown height (Safra Excavation Archives).

\section{Field D Squares 3 and 5 - City Gate Complex}

A portion of a city gate complex was excavated in the 2019 season. The western half of the gate was found in Square D3 with the eastern half found in Square D5. A 2.5 m break with a threshold (D3.20=D5.17) was found in the outer city wall (D3.14; D5.7). Paving stones (D3.21; D5.20), smooth from wear, were discovered north of the threshold. Both west and east of the gate, two long rectangular stones (D3.20; D5.21) run perpendicular to the threshold. A cobble/beaten earth surface (D5.19) was found south of the threshold which was used to level the surface of the bedrock (D3.16). Two large walls (D1.2; D3.2; D5.8=15) with benches (D3.9; D5.16) lined a roadway from the gate into the settlement. A long room was found on the other side of those walls on both the east and west of the street. The room on the east was completely excavated with a doorway leading from the room to the street and a layer of ash evident. The room on the west was 
only partially excavated but seems to parallel the eastern room (Gregor, Ray, and Moody 2019: 6).

Field D Squares 1, 2, and 6 - Interior Buildings/Phasing

Squares D1, D2, and part of Square D6 were excavated in 2018 and revealed several rooms forming at least two buildings (Gregor et al. 2018: 6). The phasing inside these rooms is fairly consistent with the rest of the site, and presented the clearest picture of the history of Field D. The bedrock (D1.5, 9, 13; D2.7, 12, 16; D3.16, 18; D4.7; D5.5, 11,$14 ;$ D6.5, 8) was filled in with red-bricky material (D1.6, 12; D2.5, 8, 13; D3.13, 17; D4.6; D5.9; D6.4, 12) upon which the walls (D1.2, 10, 11; D2.2, 6, 9; D3.2, 14, 19; D4.2; D5.4; D6.7, 11, 14-16) were laid, similarly to Fields A-C. On top of this material, flatlying early Iron Age I diagnostic sherds were found in D2.8, indicating the first occupational layer (D1.8; 14; D3.11; D5.4, 19; D6.13). In 2018, the southeastern room in Square D1 was found to have "part of an early Iron Age I biconical jar and several grinding stones, pounders, and a possible hob" (Gregor et al. 2018: 6). However, it was discovered that this room had no doorway when the northern balk of Square D2 was removed in the 2019 season. Further excavation is needed to determine the function of these rooms.

Evidence of a conflagration was found with ashy layers present above the first occupational layer. There are no clear occupation layers after the destruction phase indicating either erosion or an abandonment phase (D1.3, 4, 7; D2.3, 4, 11, 14; D3.4-8, 10, 12, 15; D4.3-5; D5.2, 3, 10, 12, 13, 18; D6.2, 3, 6, 9, 10). The erosion/abandonment layers presented mostly Iron Age I pottery with a few Iron Age II sherds. The topsoil above this contained Iron Age I and II pottery with two Byzantine-period body sherds. 


\section{Summary of Casemate Wall System}

A freestanding casemate wall system was discovered in each of the four excavation fields with the walls in Fields A-C excavated in 2018 and the walls in Field D excavated in 2019. These walls were consistently constructed with large field stone and small chink stones and created ca. 5.0-6.5 m long x 2.0-2.25 m wide broad rooms (Gregor, Ray, and Moody 2019: 2). They were built directly on uneven bedrock with the crevices in the bedrock being "filled with a densely-packed, sterile, red-bricky-like material, lacking material culture" (Gregor, Ray, and Moody 2019: 2). The walls themselves vary only slightly in thickness. The one to two-row outer wall is ca. $0.90-1.10$ $\mathrm{m}$ thick. The one-row inner wall is ca. $0.50-0.80 \mathrm{~m}$ thick. The single-row cross walls are ca. $0.55-0.95 \mathrm{~m}$ thick. Fields B-D have revealed entryways built into the inner wall that connect the broad rooms of the casemate into rooms of another structure built just inside

the inner wall. The initial construction of the casemate wall system dates to the early Iron Age I in each field based on the flat-lying pottery found on the earliest occupational surface (Gregor, Ray, and Moody 2019: 3).

\section{Preliminary Conclusions}

The first settlement at Kh. Safra was established in the early Iron Age I. Pottery forms indicate this could have been as early as the $13^{\text {th }}$ century B.C. The inhabitants flattened out the bedrock and filled the crevices with a red-bricky material upon which they built a casemate-style city wall. This settlement was destroyed by fire during Iron Age I as evidenced by thick ash layers which were found in each field. A second settlement (possibly built by the same people who built the first settlement) established themselves at Kh. Safra shortly after and remained until the site was destroyed again 
sometime in the early Iron Age II most likely by an earthquake. The site was abandoned after this potential earthquake destruction. Evidence of a possible squatter occupation during this period of abandonment is seen in the presence of some late Iron Age sherds. Kh. Safra remained abandoned until the Byzantine period. A significant structure was built in Field A, pitting activities occurred in Field B, and surface sherds were found throughout each field, all dating to the Byzantine period. The site was then abandoned for the final time with no further evidence of occupation after the Byzantine period.

Excavations in the first two seasons revealed 445 objects (Gregor et al. 2018: 8; Gregor, Ray, and Moody 2019: 7). Of those objects, 245 were related to agricultural activities, 48 were textile objects, 17 were pieces of jewelry, 10 were recreational artifacts (i.e., gaming pieces and buzz toys), and 8 were related to warfare activities (Figure 21). The small finds, as well as the site's fortifications, indicate that Kh. Safra was most likely a typical domestic settlement with a focus on farming and herding activities, especially during the first two occupations.

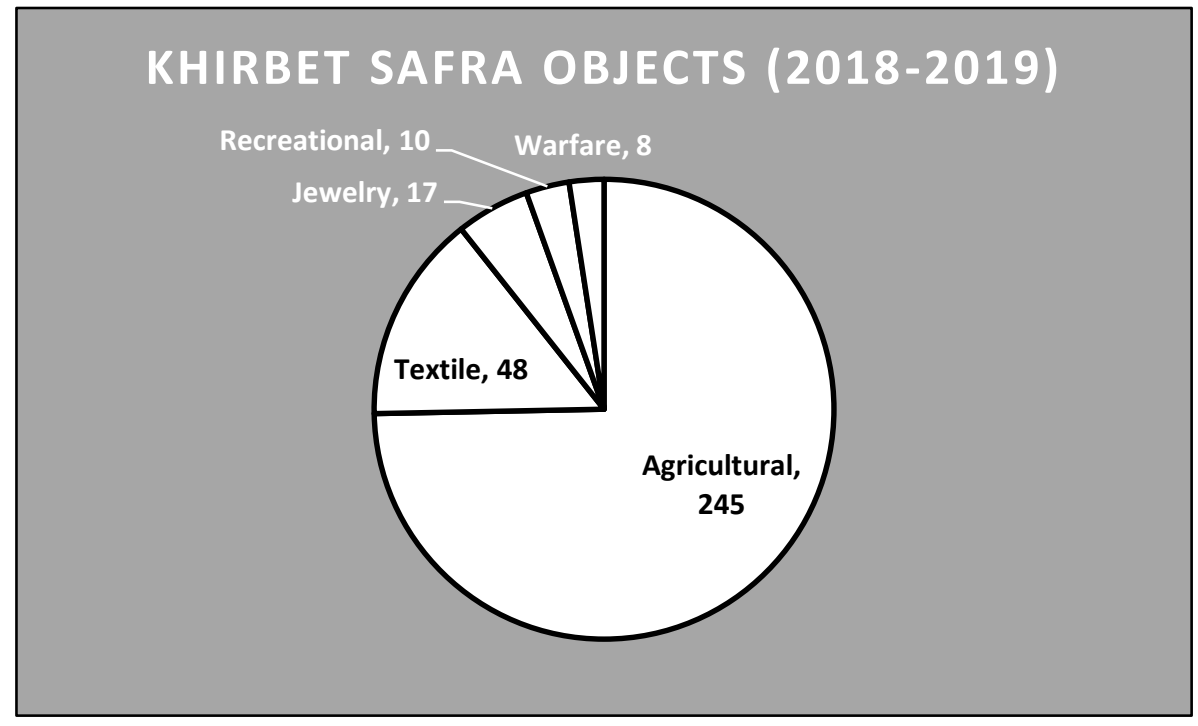

Figure 21. Chart representing objects found in 2018 and 2019 seasons at Khirbat Safra. 


\section{CHAPTER 4}

\section{IRON AGE I CASEMATE WALL SYSTEMS IN TRANSJORDAN}

There are four other sites in Transjordan where casemate wall systems dating to Iron Age I have been found. Khirbat al-Ma'mariyah, Khirbat al-Mudayna al-'Aliya, Khirbat al-Mudayna al-Mu'arrajah, and Khirbat al-Lahun are all located on the Karak Plateau, between 27 and $46 \mathrm{~km}$ southeast of Kh. Safra (Figure 22). A brief introduction to each site, a history of their excavation, and a presentation of the available data on each site's casemate wall system will be discussed in this chapter.

\section{Khirbat al-Ma'mariyah}

Khirbat al-Ma'mariyah (31 24 '46.0”N 3549'17.0'E; Figure 23) was discovered in 2000 by Friedbert Ninow as part of the Wadi ash-Shkafiya Survey and a few small sondages were carried out from 2002 to 2005 (Ninow 2008: 81). The site is on a high

ridge that rises from the wide bed of the Wadi al-Mujib and overlooks the point where the Wadi ash-Shkafiya empties into the southern branch of the Wadi al-Mujib (Figure 24; Ninow 2004a: 436). According to Ninow, it is "essentially a one-period site and dates to the Iron I Age (ca. 1200-1000 BCE) .... Whereas all the other Iron I sites are found in rather remote areas on top of the plateau, Kh. al-Ma'mariyah is situated on the crossways of important routes that connected the northern Dhiban plateau with the southern Moabite plateau. Most of the traffic that crosses Wadi al-Mujib had to pass by this site" (Ninow 


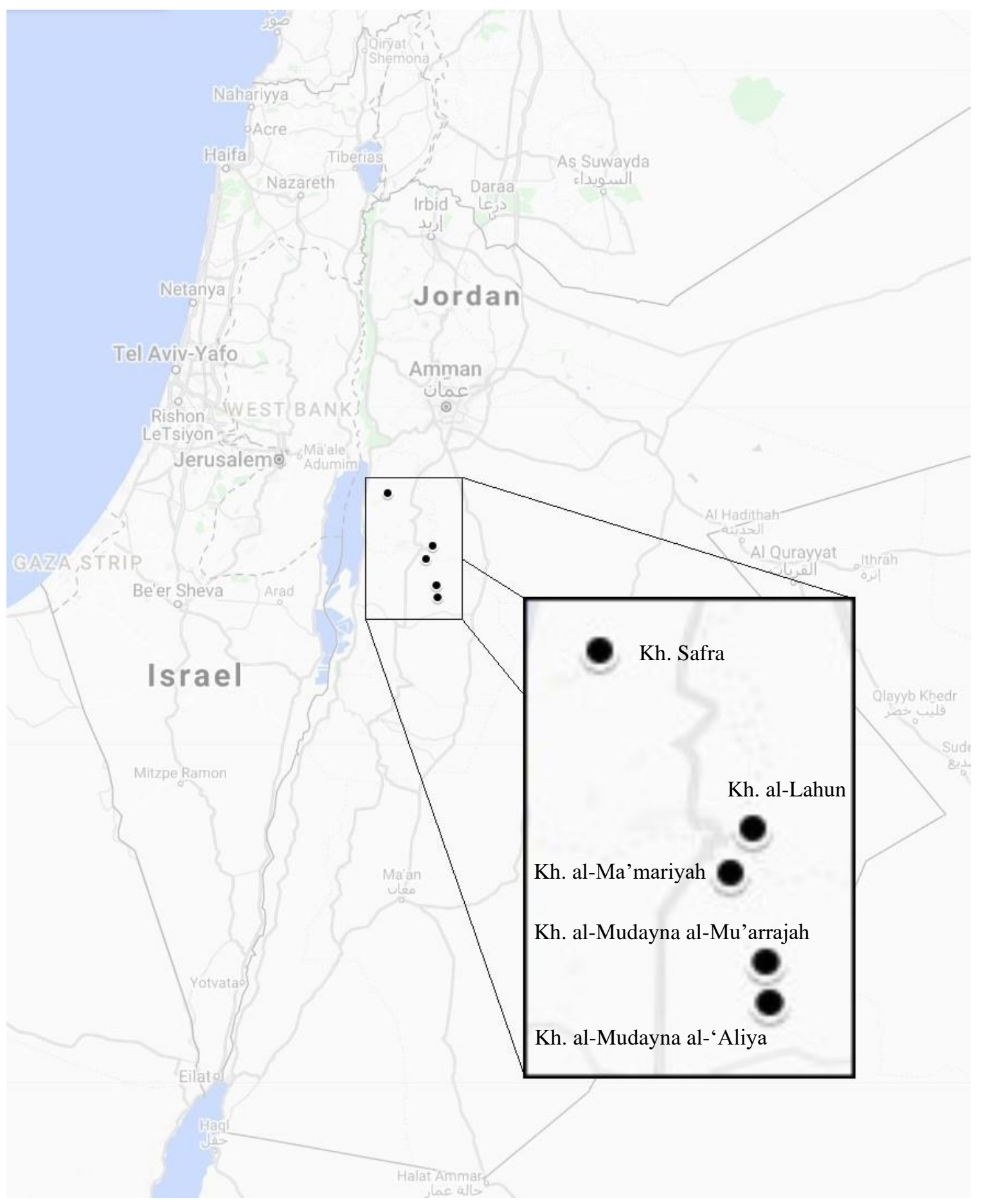

Figure 22. Map of sites with Iron Age I casemate wall systems in Transjordan. 


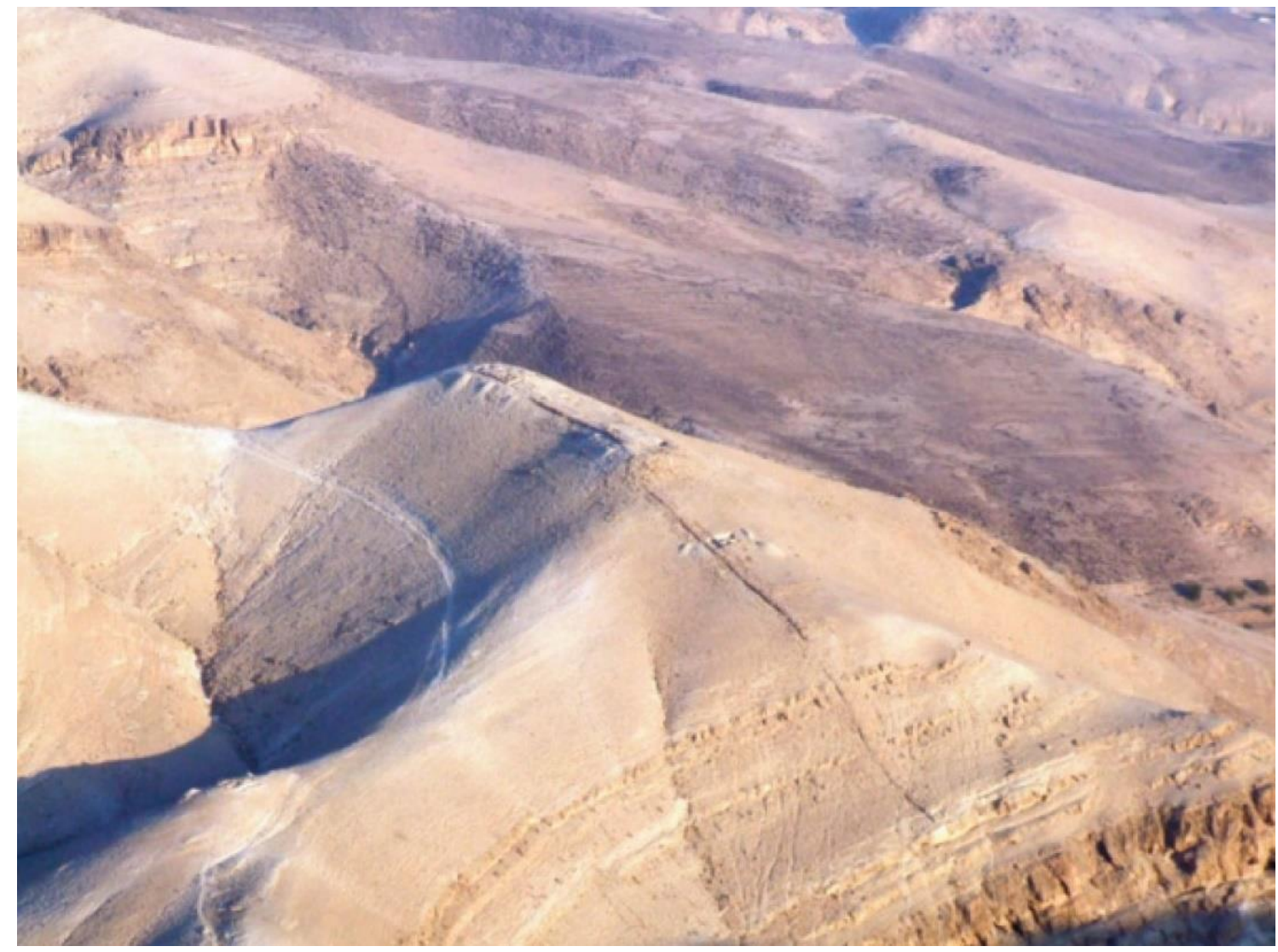

Figure 23. Aerial of Kh. al-Ma'mariyah (from David 2017: 163). 


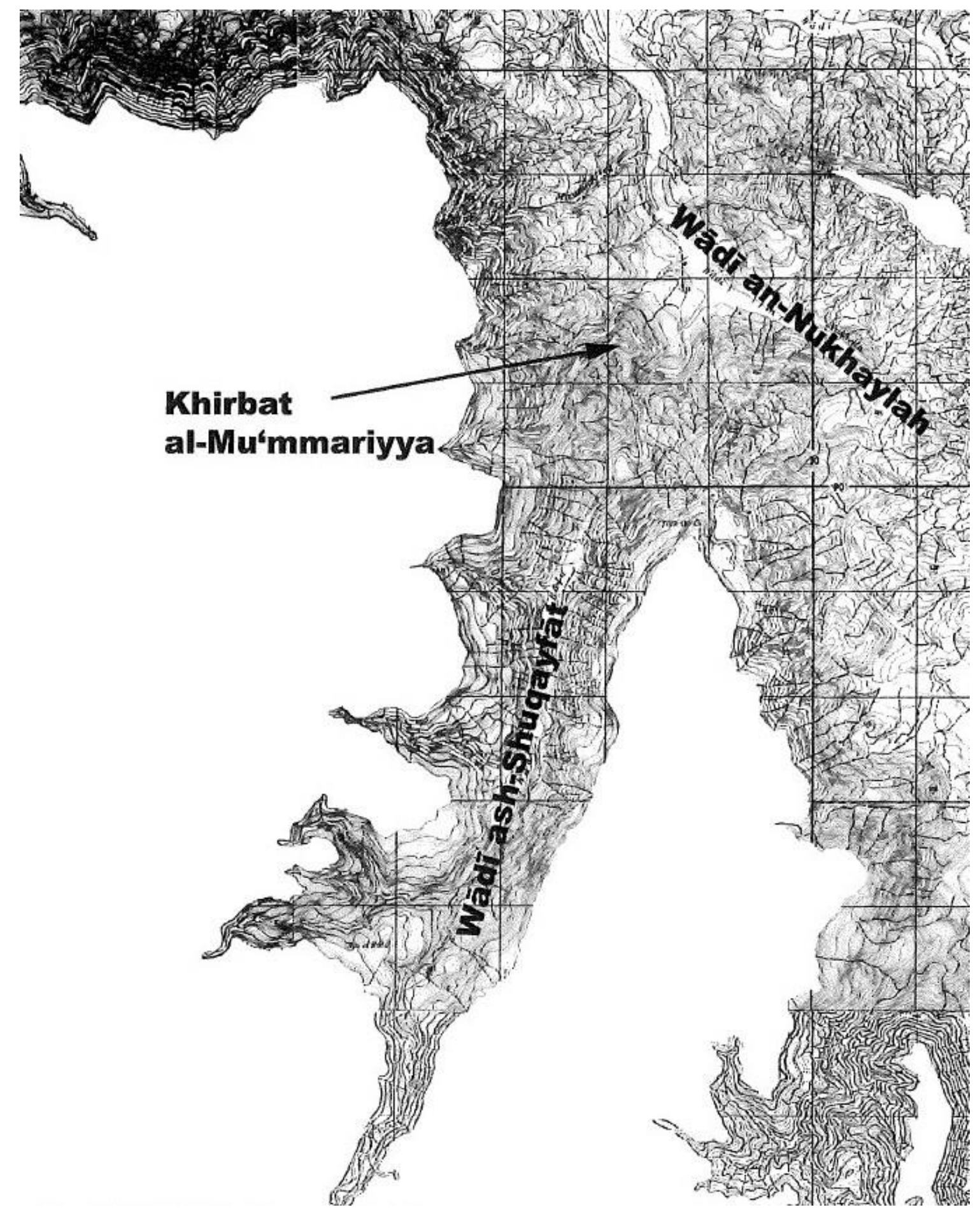

Figure 24. Region of the Wadi ash-Shkafiya Survey (from Ninow 2006b: 147). 
2007: 4). Kh. al-Ma'mariyah was built on a slope, rather than level ground with an $80 \mathrm{~m}$ height difference between its eastern and western sides and forms a large triangle (David 2017: 162). In his article titled "In Search of the 'City Which is in the Middle of the Valley'," Ninow proposes that Kh. al-Ma'mariyah is the unnamed settlement mentioned in Deut 2:36, Josh 13:9, and 2 Sam 24:5 (Ninow 2002a: 125-127).

A massive casemate wall with a width of nearly $5.0 \mathrm{~m}$ serves as the site's main fortification with the outer wall having a width of $1.2 \mathrm{~m}$. The casemate walls are well preserved. The southern wall is almost complete, while erosion occurring in the lower settlement has caused a few small sections of the northern wall and most of the eastern wall to disappear (Ninow 2004a: 436). Despite the erosion, nearly $300 \mathrm{~m}$ of city wall is traceable on both the northern and southern walls (Ninow 2006a: 465).

The upper settlement is dominated by a citadel (24 m x $17 \mathrm{~m}$; Figure 25) which is integrated into the casemate walls with the outer casemate wall also being the outer wall of the citadel (Ninow 2004b: 259). The entrance (B2) to the citadel is in the area where the northern casemate wall (W4000) connects to the citadel. This wall had a width of 1.3 to $1.4 \mathrm{~m}$ (Ninow 2004b: 262). This entrance (beginning at $1.65 \mathrm{~m}$ wide and eventually becoming nearly $3.0 \mathrm{~m}$ wide) leads to a spacious courtyard (A2) in the middle of the citadel. The western side of the citadel had several small rooms (A1/R1, A3/R2, R3) which were full of stone debris. This led Ninow to conclude that at least this section of the citadel had two floors (Ninow 2004b: 260-61). Excavations discovered that the outer casemate wall (W1000) on the southern side of the citadel runs into the eastern wall (W400) of the citadel rather than being incorporated into the citadel's architecture like 


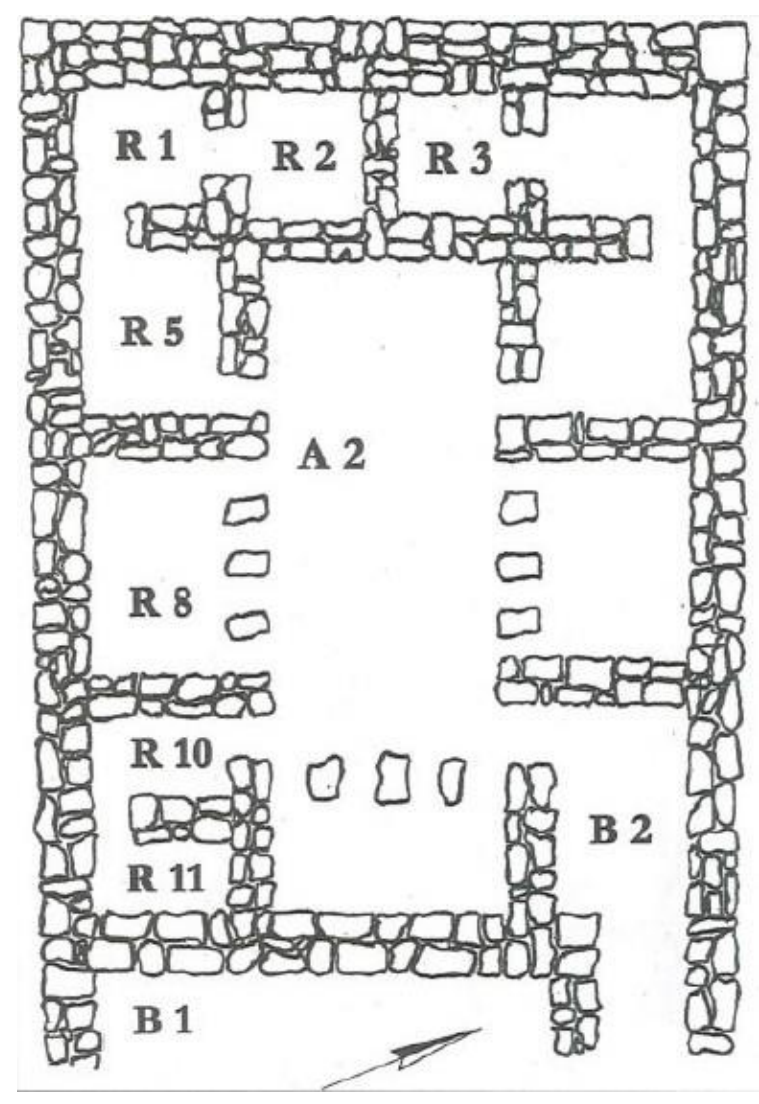

Figure 25. Citadel at Kh. al-Ma'mariyah (from Ninow 2004b: 259).

what was found on the northern side (Ninow 2004b: 261). Ceramic finds date the citadel to Iron Age I (Ninow 2004a: 437).

Approximately 25-35 $\mathrm{m}$ from the citadel, along the southern casemate wall (W1000/W2000), a casemate room (C1; Figure 26) was excavated. One transverse wall was excavated (W1010) while another was in the eastern balk. An entrance into the casemate was found in the northwest corner of the room with a width of about $1.0 \mathrm{~m}$ (Ninow 2004b: 262). The room itself measured nearly $5.0 \mathrm{~m}$ wide and at least $7.0 \mathrm{~m}$ long (including W1010; Ninow 2004b: 263). Continuing south along the casemate walls, semicircular installations appear on both the northern and southern outer casemate walls at the point where the upper and lower settlements are separated (Ninow 2004a: 436). 


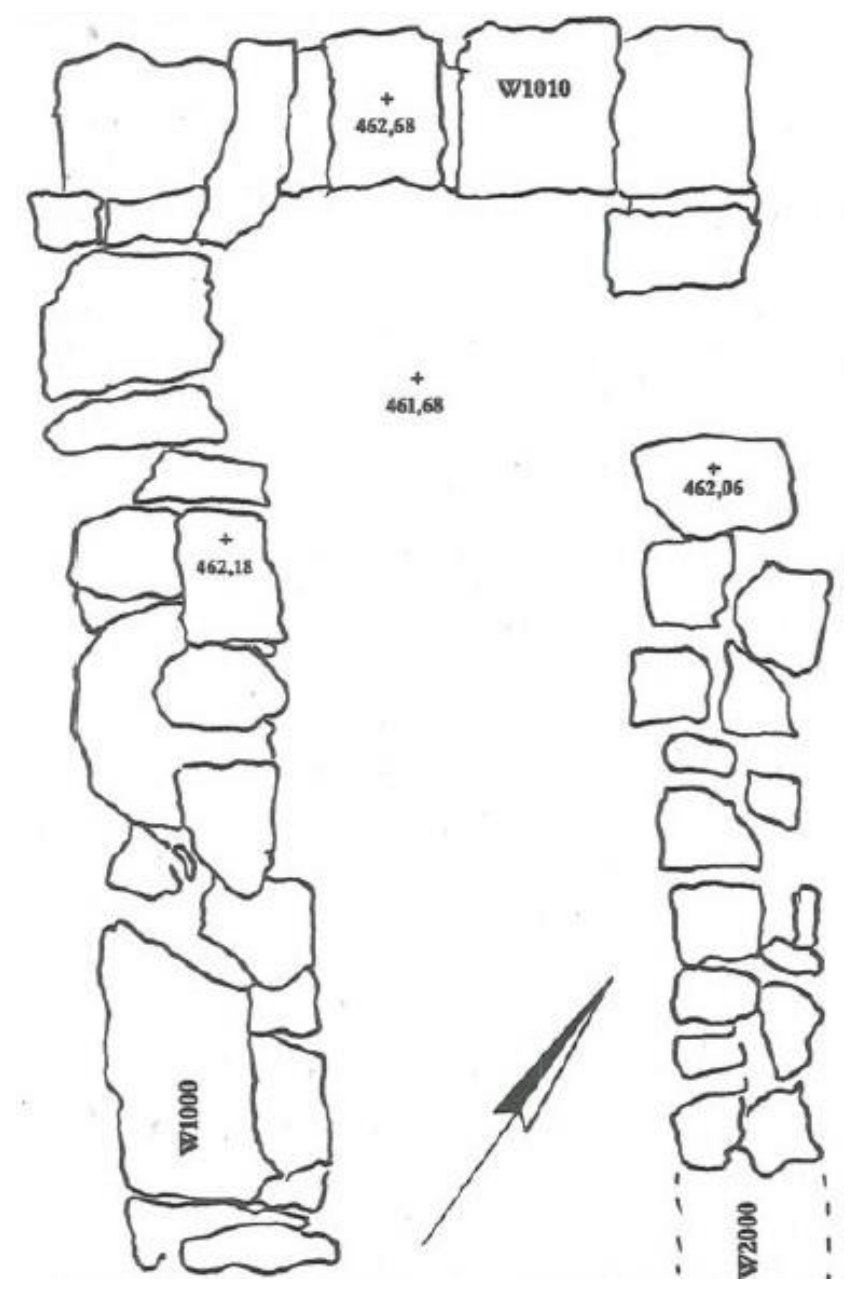

Figure 26. Kh. al-Ma'mariyah C1 (from Ninow 2004b: 263).

The last room (F1; Figure 27) of the southern casemate wall where the casemate wall system begins to turn to the north (at the site's lowest point) was excavated along with rooms adjacent to the casemate wall (Area G; Figure 28). Since the lower settlement was located on such a steep angle, the builders of this site had to either cut into the bedrock or fill it in with earth in order to create a flat foundation, forming a type of terrace-like system (Ninow 2006a: 475). A 5.0 x 5.0 m room was formed in Room F1 by the outer (W1000), inner (W2000), and transverse (W1001 and W5000 [possibly also the eastern outer casemate wall]) casemate walls. The walls had an average width of $1.0 \mathrm{~m}$. 


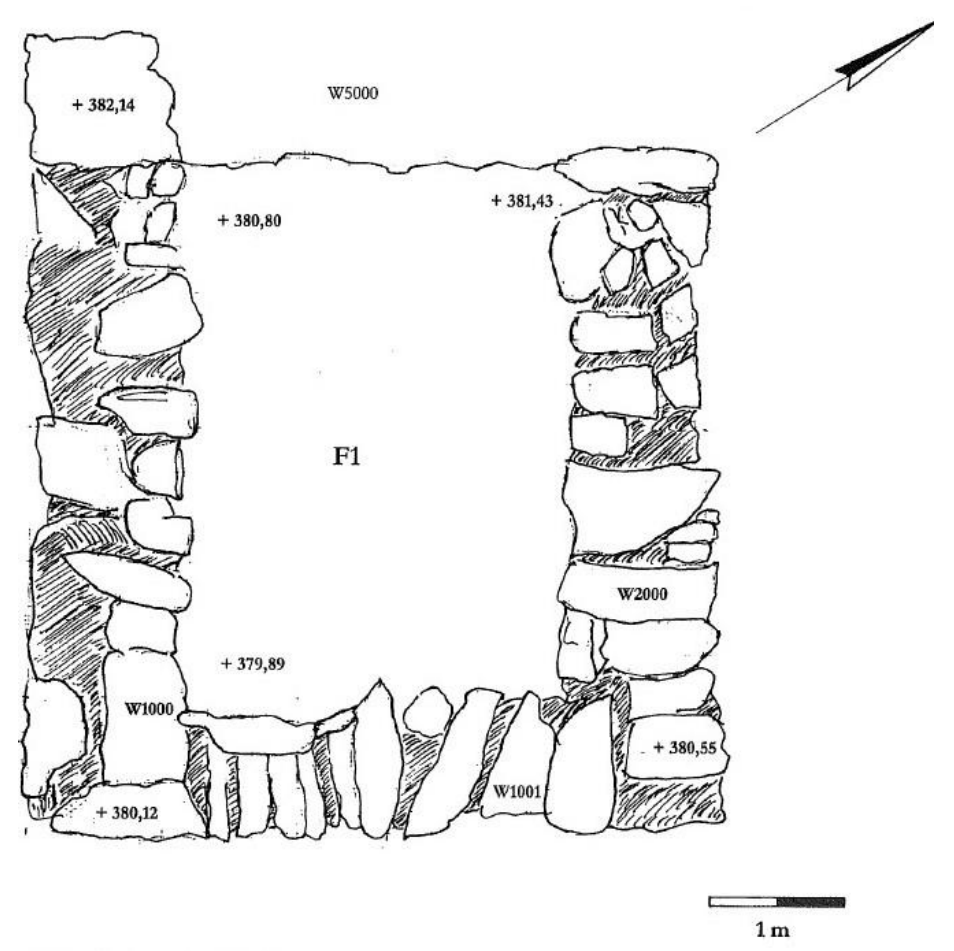

Figure 27. Kh. al-Ma'mariyah F1 (from Ninow 2006b: 152).

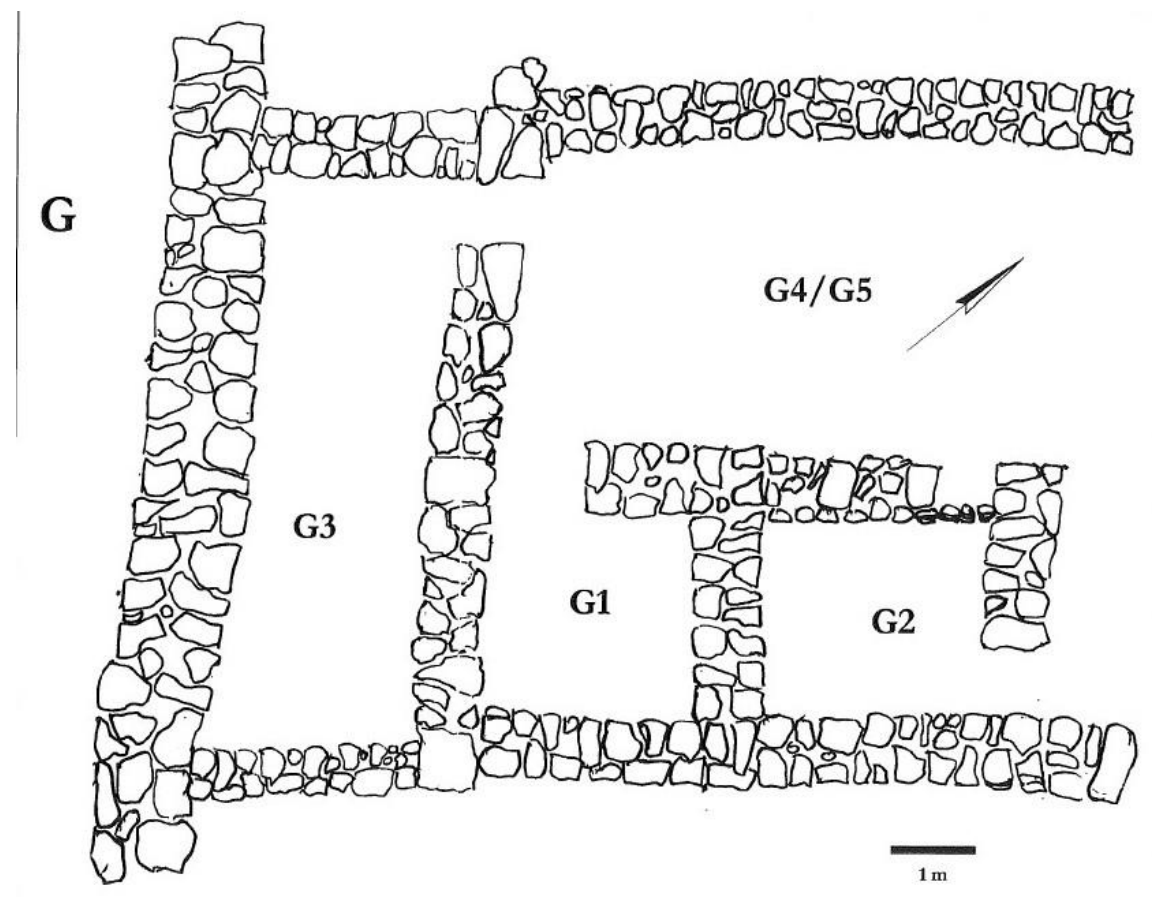

Figure 28. Kh. al-Ma'mariyah Area G (from Ninow 2006b: 153). 
Area $\mathrm{G}$ consisted of several rooms, an open area, and part of the casemate. These rooms were most likely used for food processing based on the two large querns (Figure 29), working stones, and storage jars found nearby (Ninow 2006b: 149). A tower can be seen at the point where the eastern and northern casemate wall meet in the lower settlement but is yet to be excavated (Ninow 2002b: 153).

Ninow believes that all findings at $\mathrm{Kh}$. al-Ma'mariyah are consistent with an Iron Age I occupation, in which the ceramics and objects found testify to a focus on food production and food processing by the inhabitants (Ninow 2006b: 149). Aside from being assigned a general date of Iron Age I and providing a few plates (Figures 30 and 31) nothing specific is mentioned in any excavation reports regarding the ceramics. There was no description or explanation given for the sherds included in the plates.

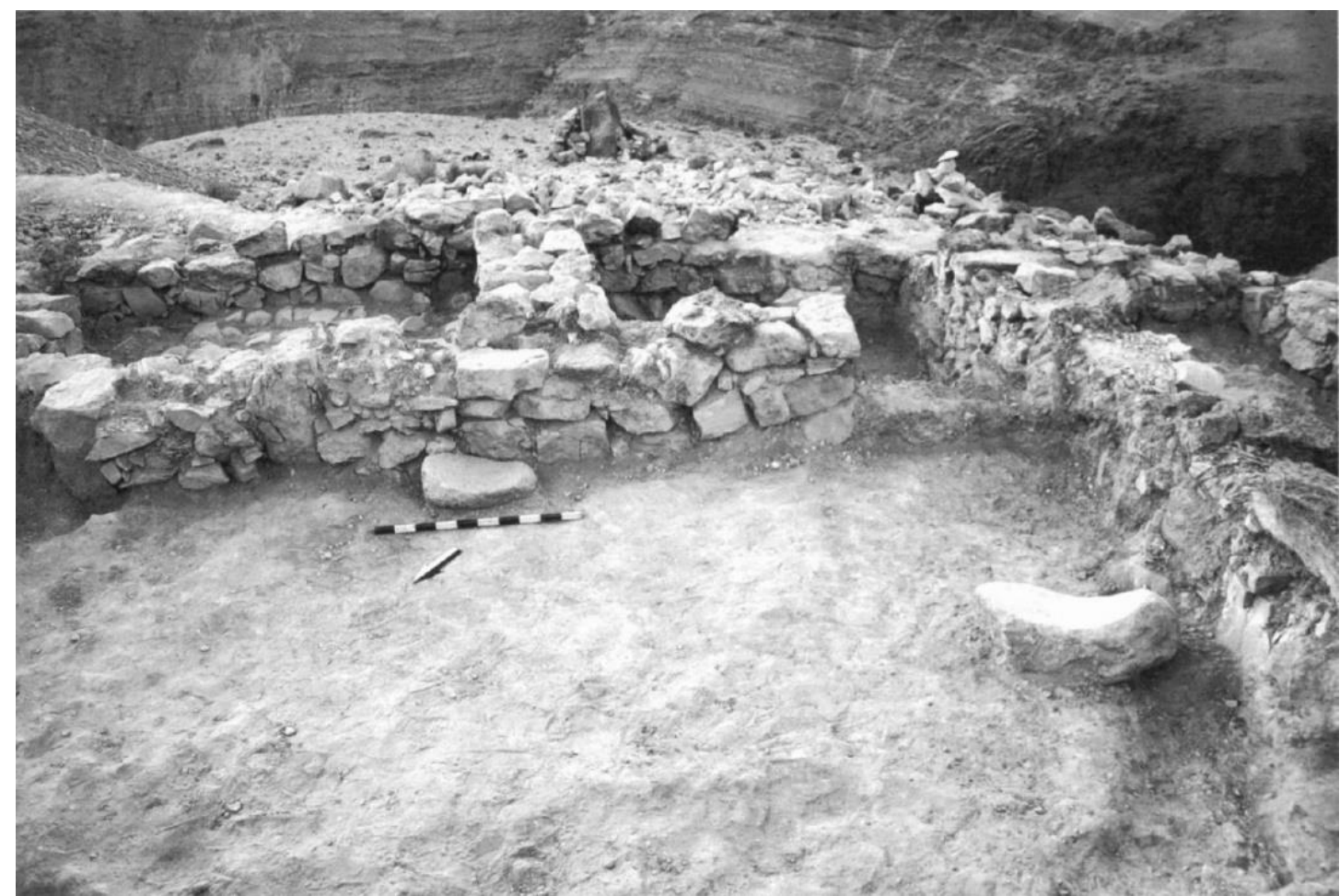

Figure 29. Grinding stones found in Area G of Kh. al-Ma'mariyah (from Ninow 2006a: 477). 

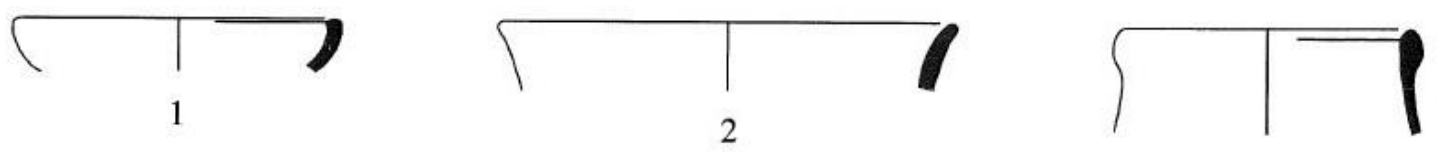

3

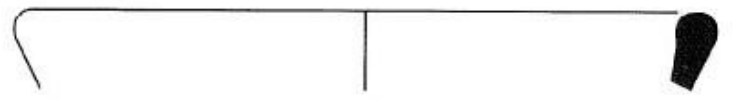

4

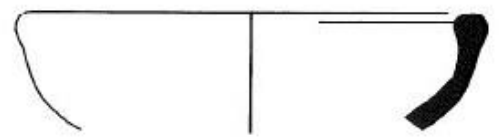

5

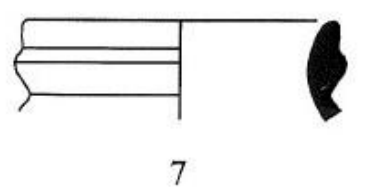

6
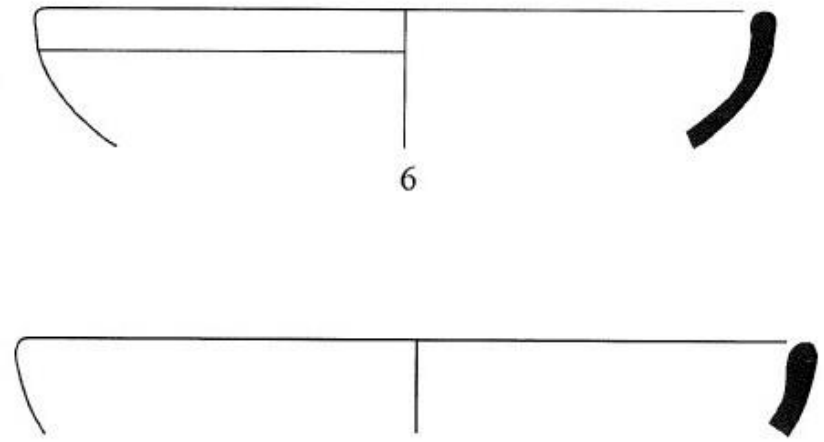

8

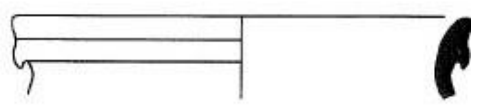

9

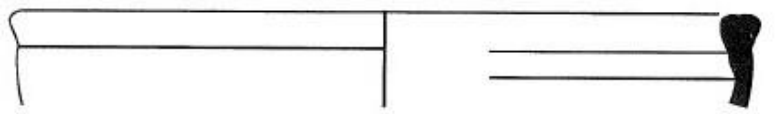

10

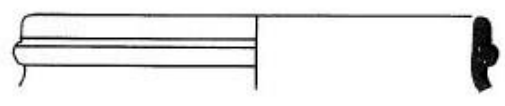

11

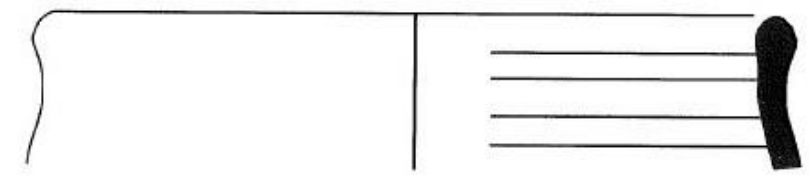

12

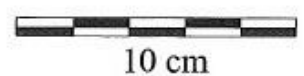

Figure 30. Iron Age I pottery assemblage from Kh. al-Ma'mariyah, 1 (from Ninow 2006b: 150). 


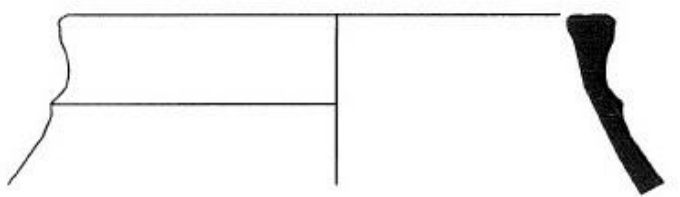

13

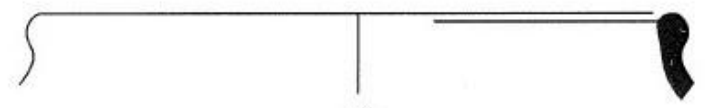

15

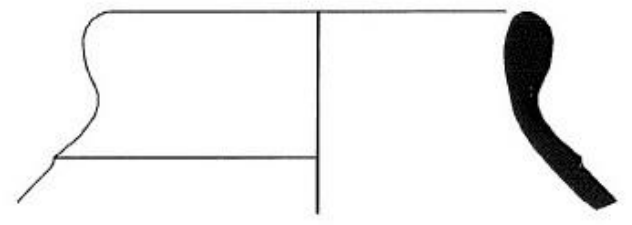

14

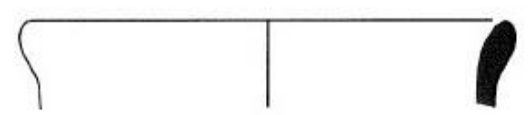

16
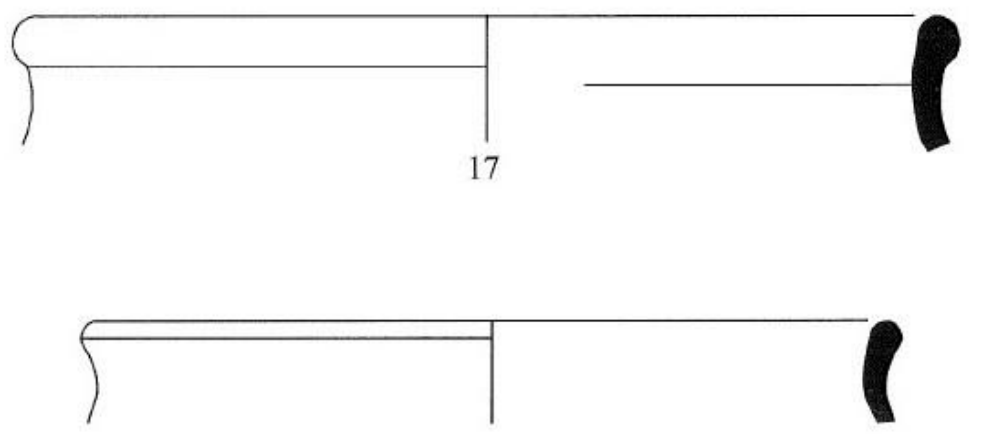

18

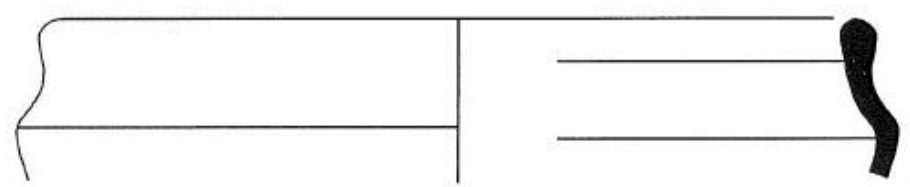

19

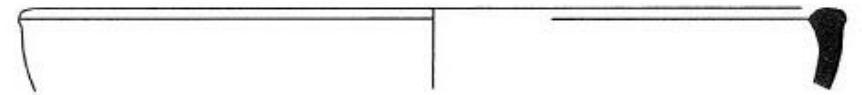

20

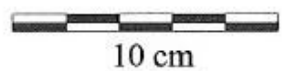

Figure 31. Iron Age I pottery assemblage from Kh. al-Ma'mariyah, 2 (from Ninow 2006b: 151). 


\section{Khirbat al-Mudayna al-'Aliya}

Khirbat al-Mudayna al-“Aliya (henceforth KMA; 31¹6'49.7"N 3552'13.8"E;

Figure 32) is a fortified settlement which overlooks the Wadi al-Mujib and its juncture with Wadi Mukhayris. It is located ca. $7.0 \mathrm{~km} \mathrm{SE}$ of es-Smakiyyah and ca. $19 \mathrm{~km}$ northeast of al-Karak. The walled settlement is surrounded to the north, east, and south by steep drops of nearly $250 \mathrm{~m}$ except for the western end where there is a land bridge protected by the remains of a massive tower and potential, unexcavated gate (Herr 2008b: 1846; Figures 33 and 34). The walls are well preserved and enclose an area of ca. $375 \mathrm{x}$ 110 m. Excavations were carried out in 1994, 1996, 1998, 2000, and 2004 by Bruce Routledge who concluded that the site consists of a single architectural phase dating to Iron Age I. Routledge follows a high chronology in his discussions on the chronology of KMA. Most of the architecture is visible on the surface with only $0.30-1.5 \mathrm{~m}$ of remains before sterile marl is reached. Routledge believes that the ceramics in connection with the architecture suggest the occupation at KMA dates to the late Iron Age IB period (Routledge and Porter 2007: 326).

In his survey of the Kerak Plateau, J. M. Miller suggested that the site may have served a military role due to its strategic location and poor agricultural situation (Miller 1991: 74). However, after several seasons of excavations, Bruce Routledge argued that KMA was an agropastoral settlement. He based this conclusion on the presence of individual houses rather than multi-house compounds whose forms cannot be considered ethnically-marked material culture (Routledge 2000: 37). An article written by Alan Farahani, Benjamin Porter, Hanna Huynh, and Bruce Routledge in 2016 on KMA provides evidence through a paleoethnobotanical approach which supports the 


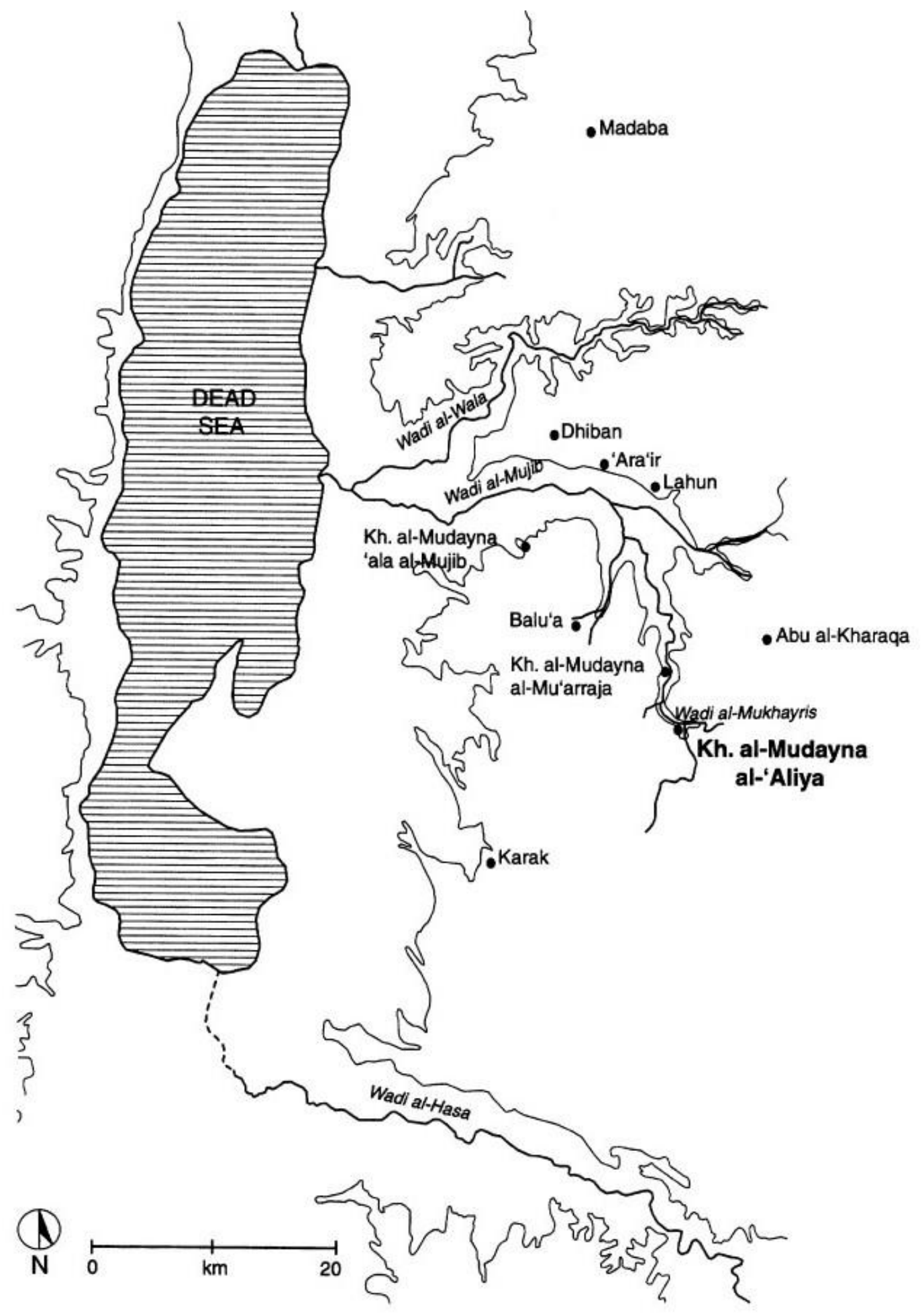

Figure 32. Map of south-central Jordan showing location of Kh. al-Mudayna al-'Aliya (from Routledge 2000: 39). 


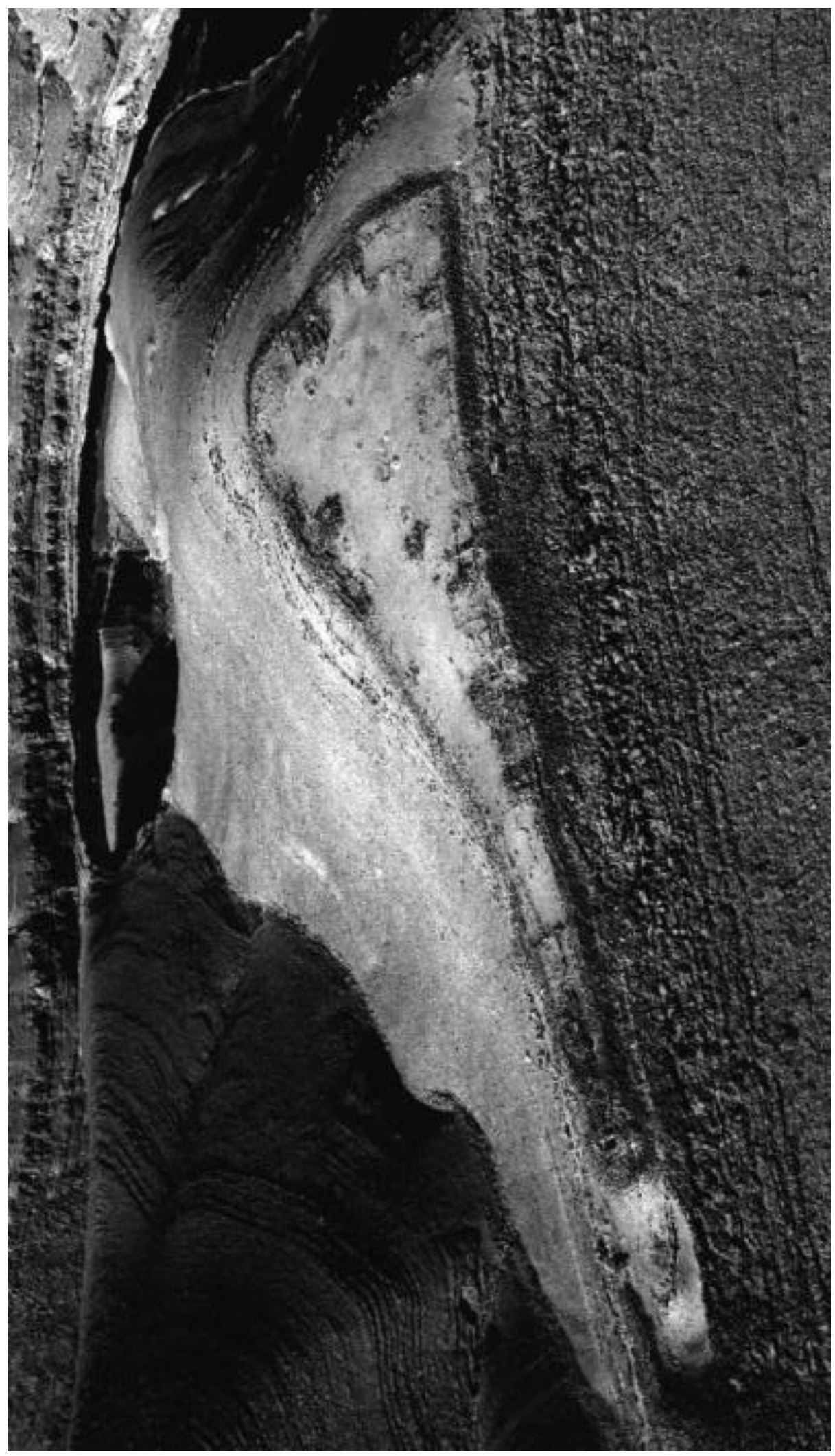

Figure 33. Aerial image of Kh. al-Mudayna al-'Aliya, looking north (from Farahani et al. 2016: 35). 


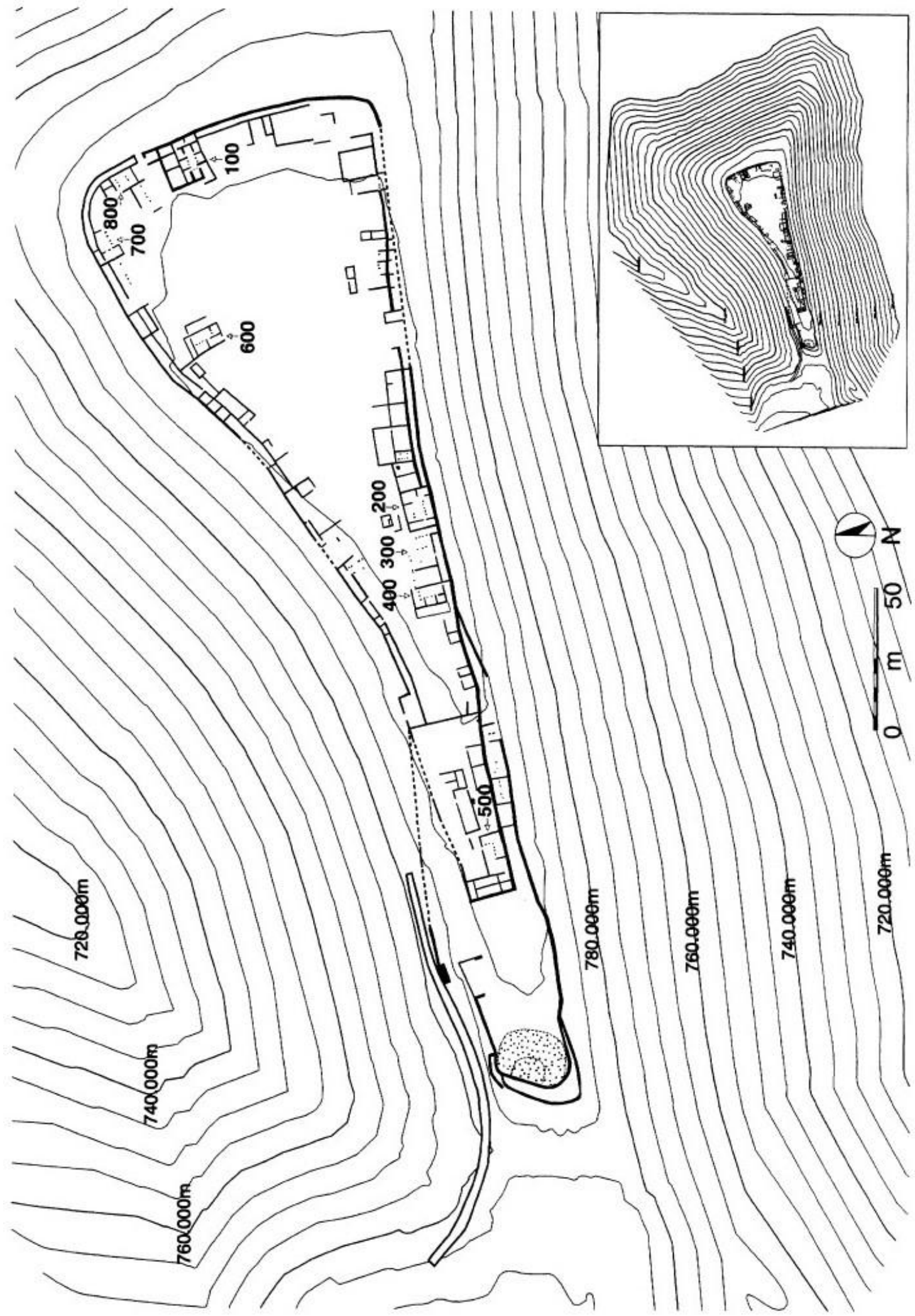

Figure 34. Top plan of the architecture and topography at Kh. al-Mudayna al-'Aliya (from Routledge 2000: 41). 
importance of crop storage and animal husbandry for the inhabitants and therefore, a site whose function was agropastoral rather than having a military role (Farahani et al. 2016: 27-89).

\section{Casemate Wall System of Khirbat al-Mudayna al-'Aliya}

The entire inhabited portion of KMA is enclosed by casemate walls covering an area of $375 \mathrm{~m}$ in length and varying between 30 and $110 \mathrm{~m}$ in width. The casemate wall system measures between 4.0 and $4.6 \mathrm{~m}$ wide with a $1.1-1.2 \mathrm{~m}$ wide outer wall, a 0.8-1.0 $\mathrm{m}$ wide inner wall, and with rooms between 2.0 and $2.4 \mathrm{~m}$ wide. The layout of the walls was determined by the topography of the site and the size and shape of the stones were determined by the fracture mechanics of the local bedrock. The only part of the site not defended with casemate walls is the western end where a 1.1-1.2 m wide single wall surrounds a tower which overlooks a short moat ( $35 \mathrm{~m}$ long x $18.75 \mathrm{~m}$ wide x $5.0 \mathrm{~m}$ deep) and the land bridge (Routledge 2000: 48-49). This tower, whose remains appear as a $32 \mathrm{~m}$ wide and $5.0 \mathrm{~m}$ high mound of collapsed stones was partially excavated with 8 of the estimated $10 \mathrm{~m}$ high foundation uncovered (Routledge and Porter 2007: 325).

Most of the buildings, both visible on the surface and excavated, are directly attached to the inner casemate wall. Routledge has estimated the number of attached houses to be between 35 and 45 (Routledge 2004: 96). However, some stretches of the casemate wall system are freestanding with no building attached and accessed directly from the central court that is free from buildings. Whether attached or freestanding, bonding patterns between walls indicate that most of the site was built up "in a single building operation" (Routledge 2004: 100). Eight buildings which were preserved enough to create a detailed top plan though nine have been excavated as of 2004. Buildings 100, 
300, 400, and 800 (Figures 35-38) are positioned in a way where their broad rooms are also the casemate rooms (rooms 109, 110, 303, 405, 804, and 805). Buildings 200, 500, and 700 (Figures 39-41) are positioned so that either a row of pillars or a solid internal wall replace the inner casemate wall (rooms 203, 501, 701, and 703), but the building itself still incorporates the casemate rooms. However, Building 600 (Figure 42) is unique in that it is not incorporated to the casemate wall, but is oriented perpendicularly to it (Routledge 2000: 49-53). In addition, none of the buildings show any use of mudbrick or plaster and were dry laid (Brown 2010: 57).

While considered an agriculturally-marginal area, most of the excavated houses contained evidence of food processing and storage, especially in Buildings 100 and 500. "Tabun, saddle quern, mortar, and collar-rim storejars" were discovered along with traces of "lentils, wheat, barley, grapes, figs, sheep, goat, pig, and freshwater crab" (BlochSmith 2015: 299). The inhabitants of KMA most likely made good use out of the perennial water source which the wadis provided them. Several cisterns located on the steep slopes also point to this.

The abandonment of this site is somewhat unclear, though it does not appear to have occurred all at once, in contrast to its foundation. Routledge believes that the large amount of post occupation deposits and lack of stone collapse suggest that Buildings 200 and 700 were used as garbage dumps and partially disassembled for building stone (Routledge 2004: 107). These two buildings were essentially abandoned. Based on the lack of post abandonment debris and the large amount of wall preservation, Buildings 100 and 500 continued to be occupied until shortly before KMA's final abandonment. This idea is further supported with the logical assumption that the inhabitants of the two 

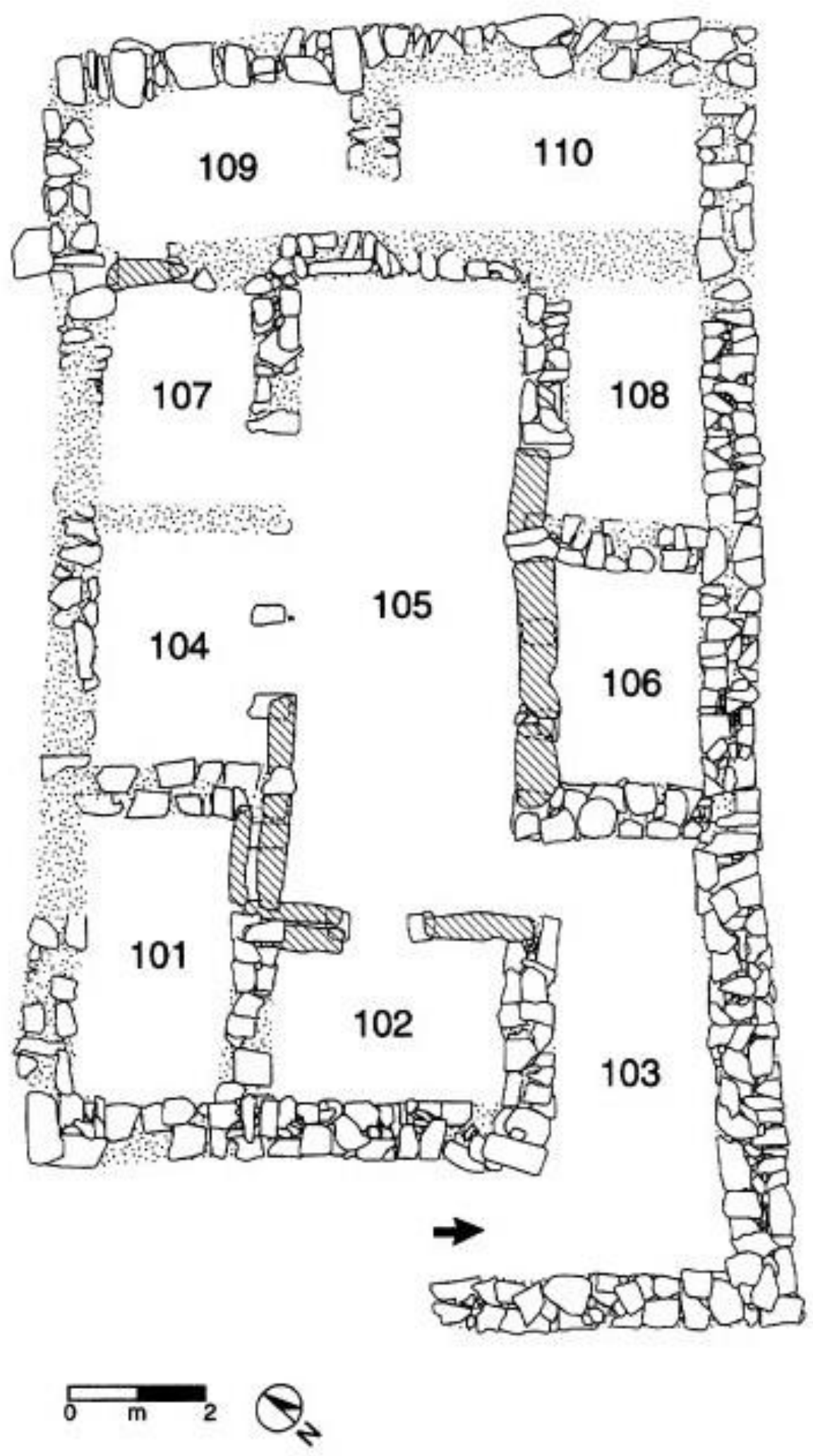

Figure 35. Top plan of Building 100 at Kh. al-Mudayna al-'Aliya (from Routledge 2000: $50)$. 


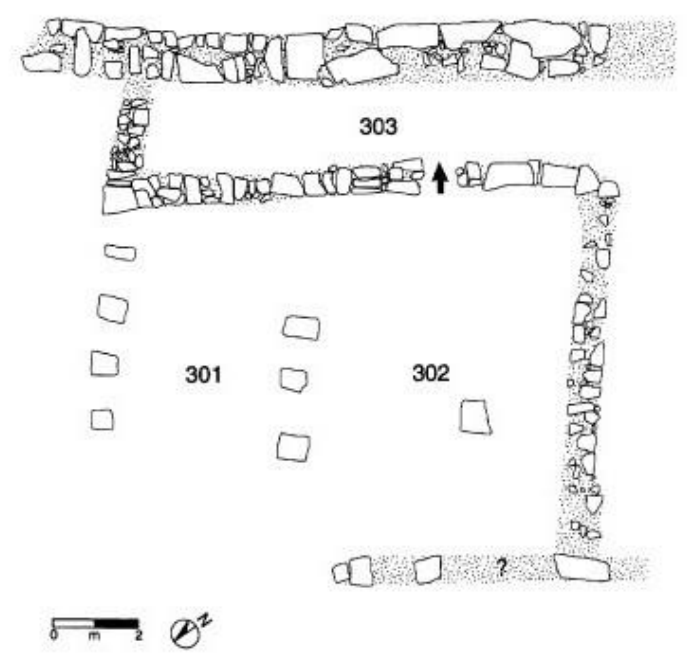

Figure 36. Top plan of Building 300 at Kh. al-Mudayna al-'Aliya (from Routledge 2000: $51)$.

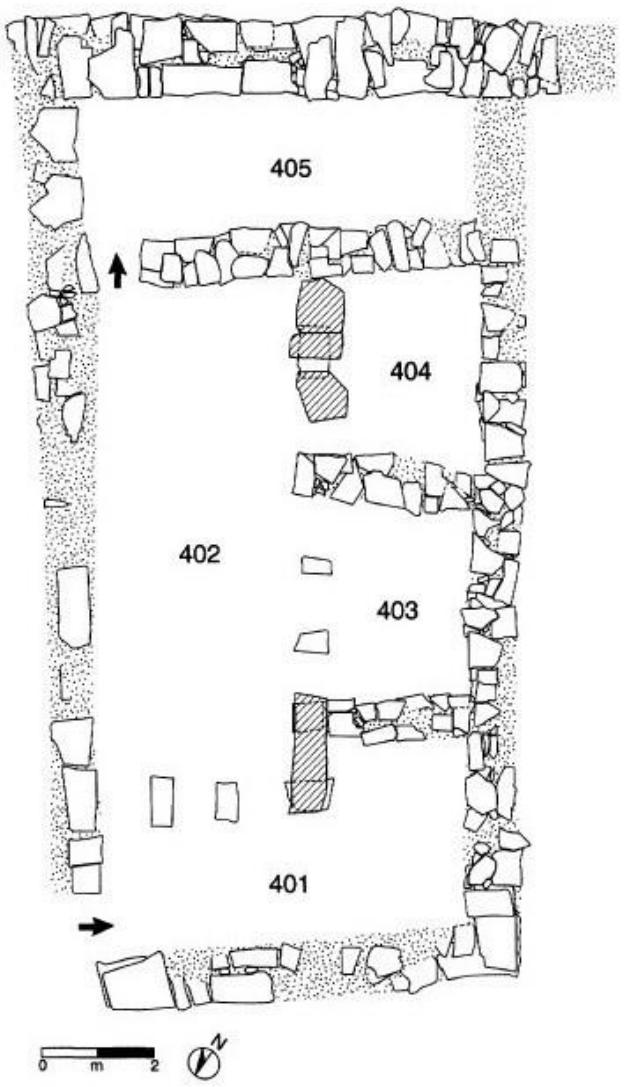

Figure 37. Top plan of Building 400 at Kh. al-Mudayna al-'Aliya (from Routledge 2000: $51)$. 


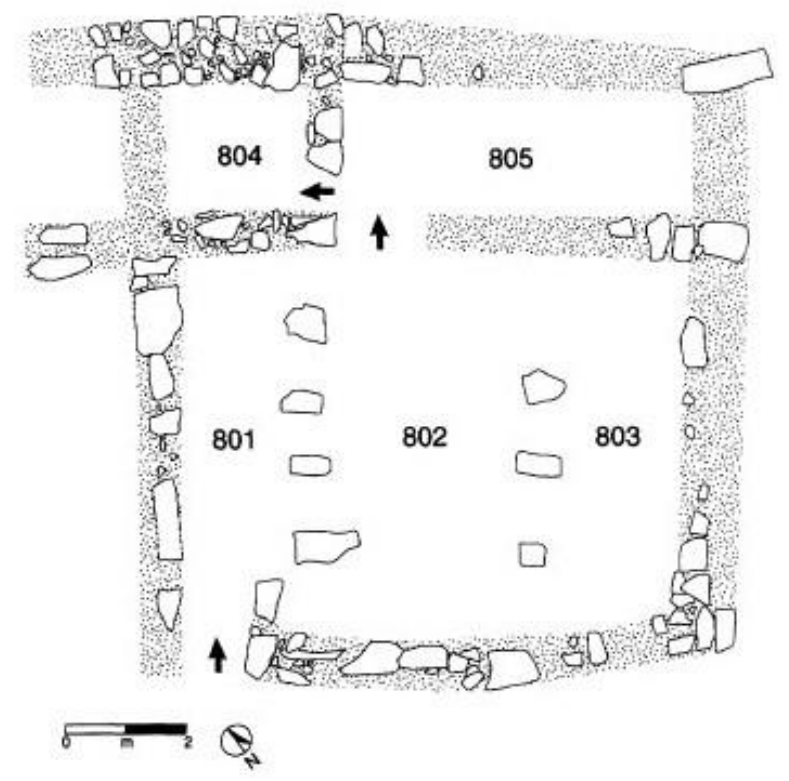

Figure 38. Top plan of Building 800 at Kh. al-Mudayna al-'Aliya (from Routledge 2000: 53).

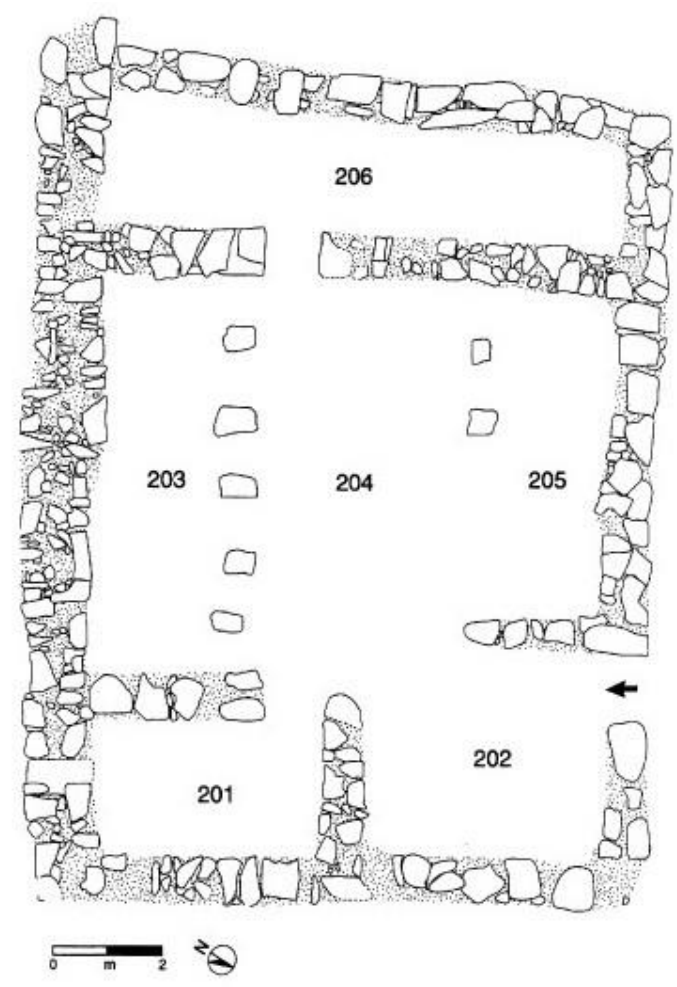

Figure 39. Top plan of Building 200 at Kh. al-Mudayna al-'Aliya (from Routledge 2000: $50)$. 


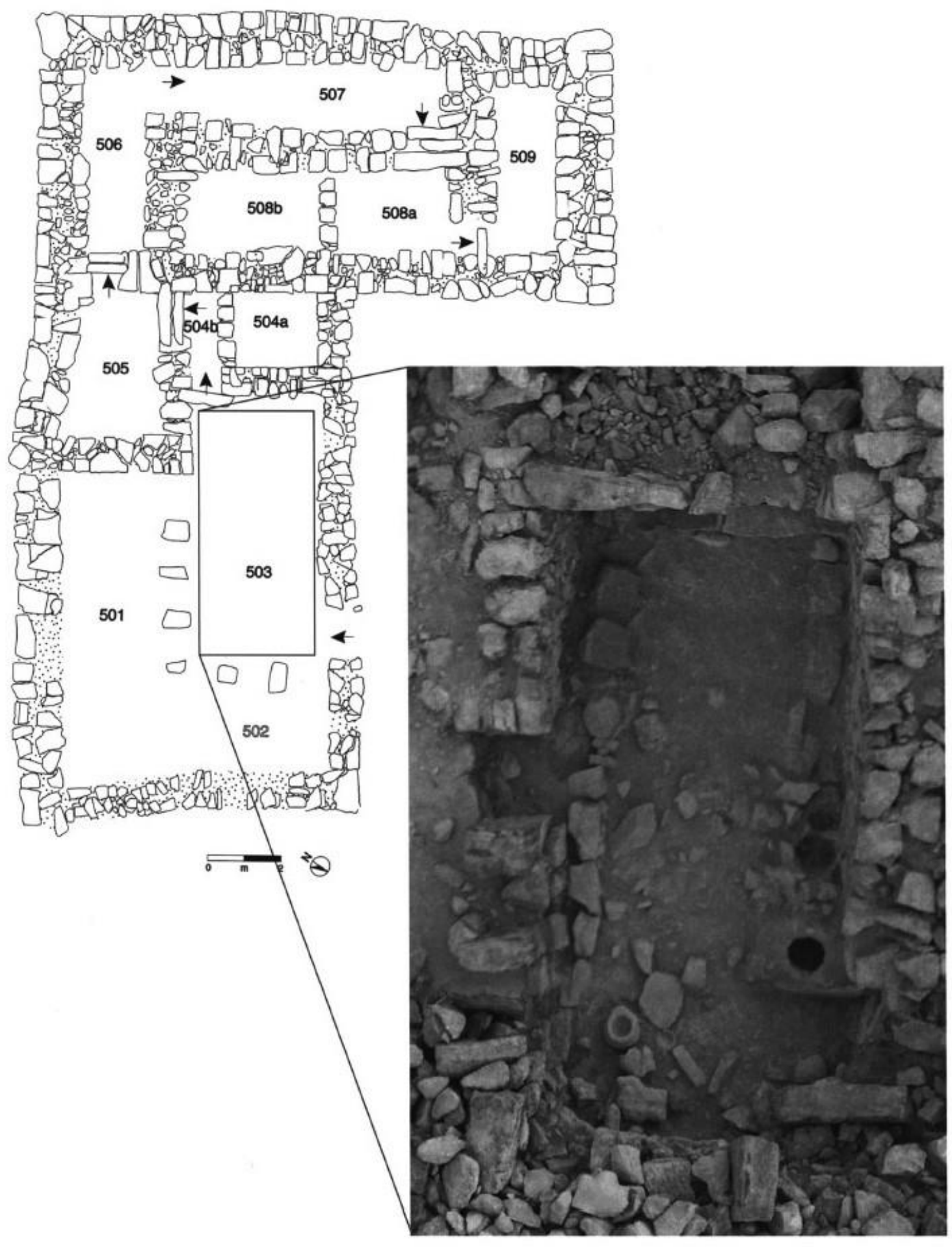

Figure 40. Top plan of Building 500 at Kh. al-Mudayna al-'Aliya (from Farahani et al. 2006: 37). 


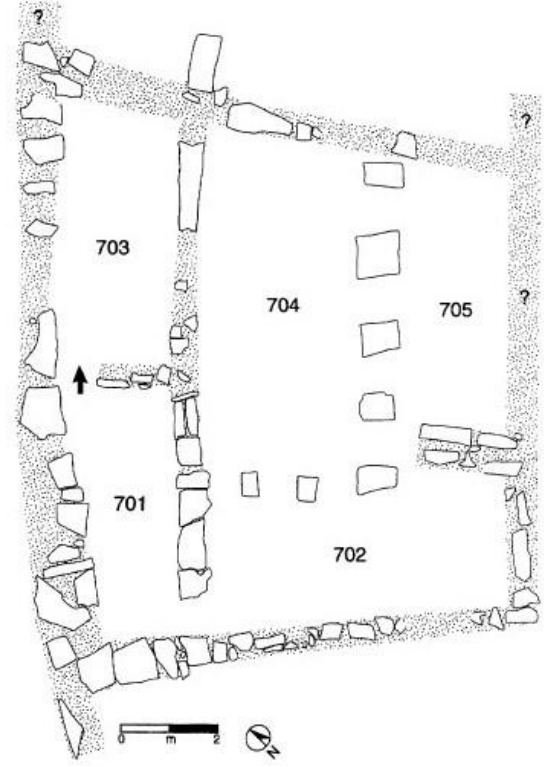

Figure 41. Top plan of Building 700 at Kh. al-Mudayna al-'Aliya (from Routledge 2000: 53).

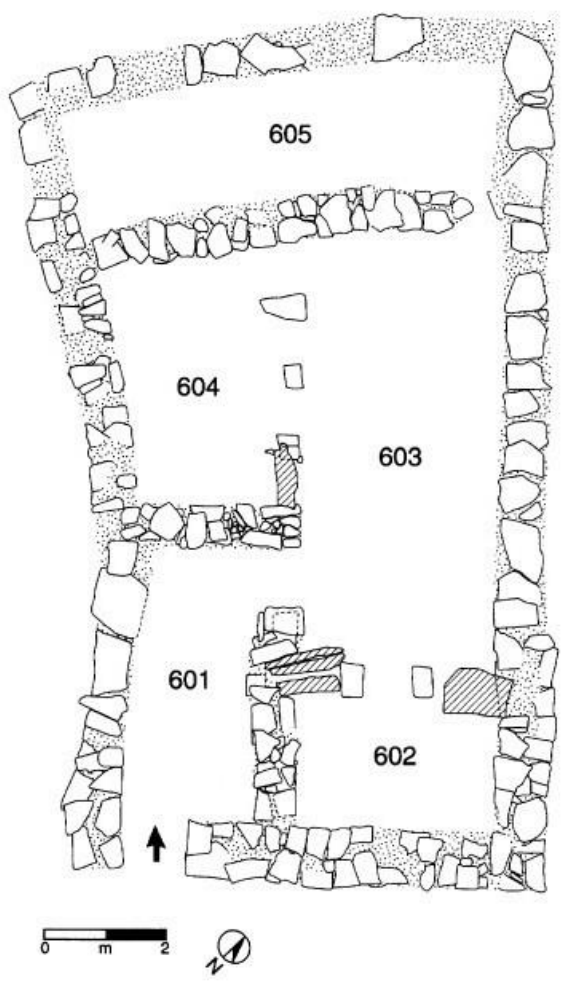

Figure 42. Top plan of Building 600 at Kh. al-Mudayna al-'Aliya (from Routledge 2000: $53)$. 
most prominent houses in both size and location (Buildings 100 and 500) would be the last to leave the settlement (Routledge 2004: 108). The other buildings (300, 400, and 600) have not been studied enough to suggest an abandonment sequence.

\section{Ceramics of Khirbat al-Mudayna al-'Aliya}

Only a small number of sherds were recovered from KMA and as of the 2000 excavation no completely restorable vessels were found. There were, however, enough sherds for Routledge to draw preliminary conclusions based on comparisons with similar sites. The pottery assemblage generally belongs to the late Iron Age I or Iron Age IB period. A few sherds exhibit a white slip which suggests a date prior to the middle of the tenth century B.C. However, typical early Iron Age I forms like biconical vessels and wide-mouthed cooking pots with everted triangular rims are completely absent from the ceramics found at KMA. Routledge argues that the forms present suggest an occupation during the last half of the $11^{\text {th }}$ century B.C.

Notable ceramic forms include: gently carinated small and large bowls (Figure 43:1-6), simple bowls with rounded sides and incurved or thickened rims (Figure 43:7-9), simple bowls with flattened and grooved rims (Figure 43:10-11), mensif bowls (Figure 44:1-2), kraters (Figure 44:3-5), cooking jugs with folded, triangular rims (Figure 44:69), cooking jugs with pinched or ridged rims (Figure 44:10), storage jars with everted and externally-thickened rims (Figure 45:1-5), ridge-necked jars (Figure 45:6-10), and onehandled jugs (Figure 45:11; Routledge 2000: 43-47). 

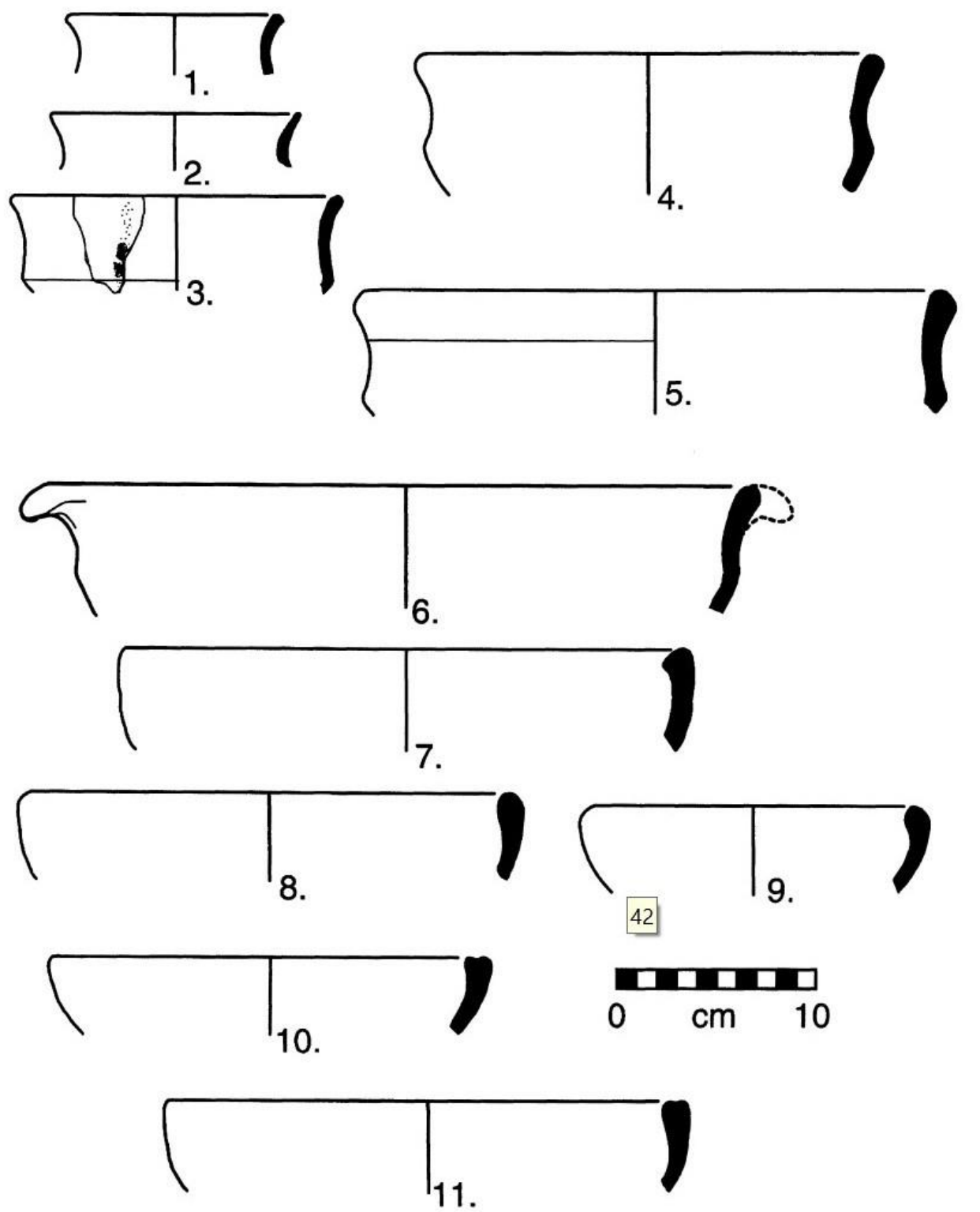

\begin{tabular}{|c|c|c|c|c|}
\hline Number & Context & Fabric & Surface Treatment & Form \\
\hline 1. $A 1.18 .14$ & Bldg. 700, Room 704 & 5 YR 7/6, reddish yellow & Slip: 10 YR $8 / 3$, very pale brown & Bowl \\
\hline 2. $A 3.1 .20$ & Bldg. 700, Looters' Pit & 7.5 YR $7 / 4$, pink & No & Bowl \\
\hline \multirow[t]{2}{*}{ 3. B1.21.2 } & Bldg. 100, Room 106 & 2.5 YR $6 / 6$, light red & Burnish & Bowl \\
\hline & & & Slip: 7.5 YR $8 / 3$, pink & \\
\hline 4. $A 1.5 .15$ & Bldg. 700, Room 704 & 2.5 YR $7 / 6$, red & Slip: 7.5 YR $8 / 3$, pink & Bowl \\
\hline 5. D1.1.29 & Looters' Pit & 2.5 YR $7 / 8$, light red & No & Bowl \\
\hline 6. Sf. 2.17 & Surface & 2.5 YR $6 / 6$, light red & Slip: 10 YR $8 / 3$, very pale brown & Bowl \\
\hline 7. $A 2.15 .1$ & Bldg. 700, Room 704 & 2.5 YR $6 / 6$, light red & No & Bowl \\
\hline 8. A3.Sf. & Bldg. 700 , Surface & 2.5 YR $6 / 8$, light red & Ext. Slip: 10 YR $8 / 3$, very pale brown & Bowl \\
\hline 9. A2.18.126 & Bldg. 700, Room 704 & $10 \mathrm{R} 5 / 8$, red & Slip: 10 YR $8 / 3$, very pale brown & Bowl \\
\hline 10. Sf.1.9 & Surface & 7.5 YR $6 / 4$, light brown & No & Bowl \\
\hline 11. $A 2.36 .40$ & Bldg. 700, Room 704 & 7.5 YR $7 / 4$, pink & No & Bowl \\
\hline
\end{tabular}

Figure 43. Iron Age I bowls from Kh. al-Mudayna al- 'Aliya (modified from Routledge 2000: 42-43). 

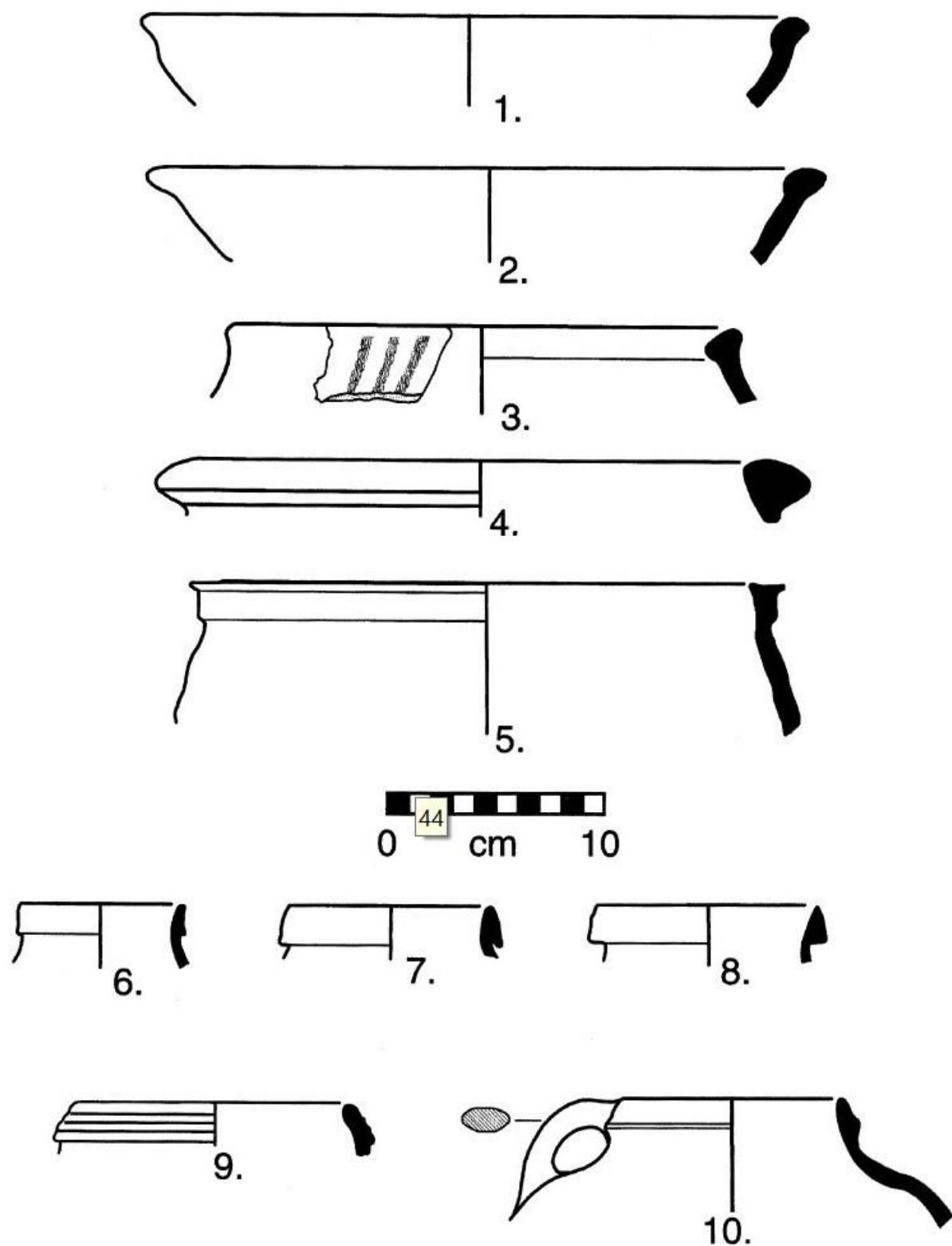

\begin{tabular}{lllll}
\hline \multicolumn{1}{c}{ Number } & Context & \multicolumn{1}{c}{ Fabric } & \multicolumn{1}{c}{ Surface Treatment } & \multicolumn{1}{c}{ Form } \\
\hline 1. E1.1.10 & Looters' Pit & 5 YR 7/4, pink & No & Bowl \\
2. SF.2.11 & Surface & 5 YR 7/4, pink & No & Bowl \\
3. A2.31.1 & Bldg. 700, Room 704 & 7.5 YR 7/4, pink & Slip: 2.5 YR 8/2, pale yellow & Krater \\
& & & Paint: 5 YR 4/4, reddish brown & Slip: 10 YR 8/3, very pale brown Krater \\
4. A2.7.28 & Bldg. 700, Room 704 & 5 YR 7/6, reddish yellow & Slip: 2.5 YR 8/2, pale yellow & Krater \\
5. B1.5.3 & Bldg. 100, Room 106 & 5 YR 7/4, pink & Cooking jug \\
6. D1.1.27 & Looters' Pit & 10 YR 4/4, dark grayish brown & Exterior blackened & Cooking jug \\
7. A1.1.92 & Bldg. 700, Room 704 & 2.5 YR 6/6, light red & Exterior blackened & Cooking jug \\
8. A1.1.45 & Bldg. 700, Room 704 & 2.5 YR 5/8, red & No & Cooking jug \\
9. 2G87.36.8 & Bldg. 200, Room 204 & 5 YR 4/4, reddish brown & No & Cooking jug \\
10. 2G87.22.19 & Bldg. 200, Room 204 & 2.5 YR 6/4, light reddish brown No & \\
\hline
\end{tabular}

Figure 44. Iron Age I bowls, kraters, and cooking jugs from Kh. al-Mudayna al-'Aliya (modified from Routledge 2000: 44-45). 

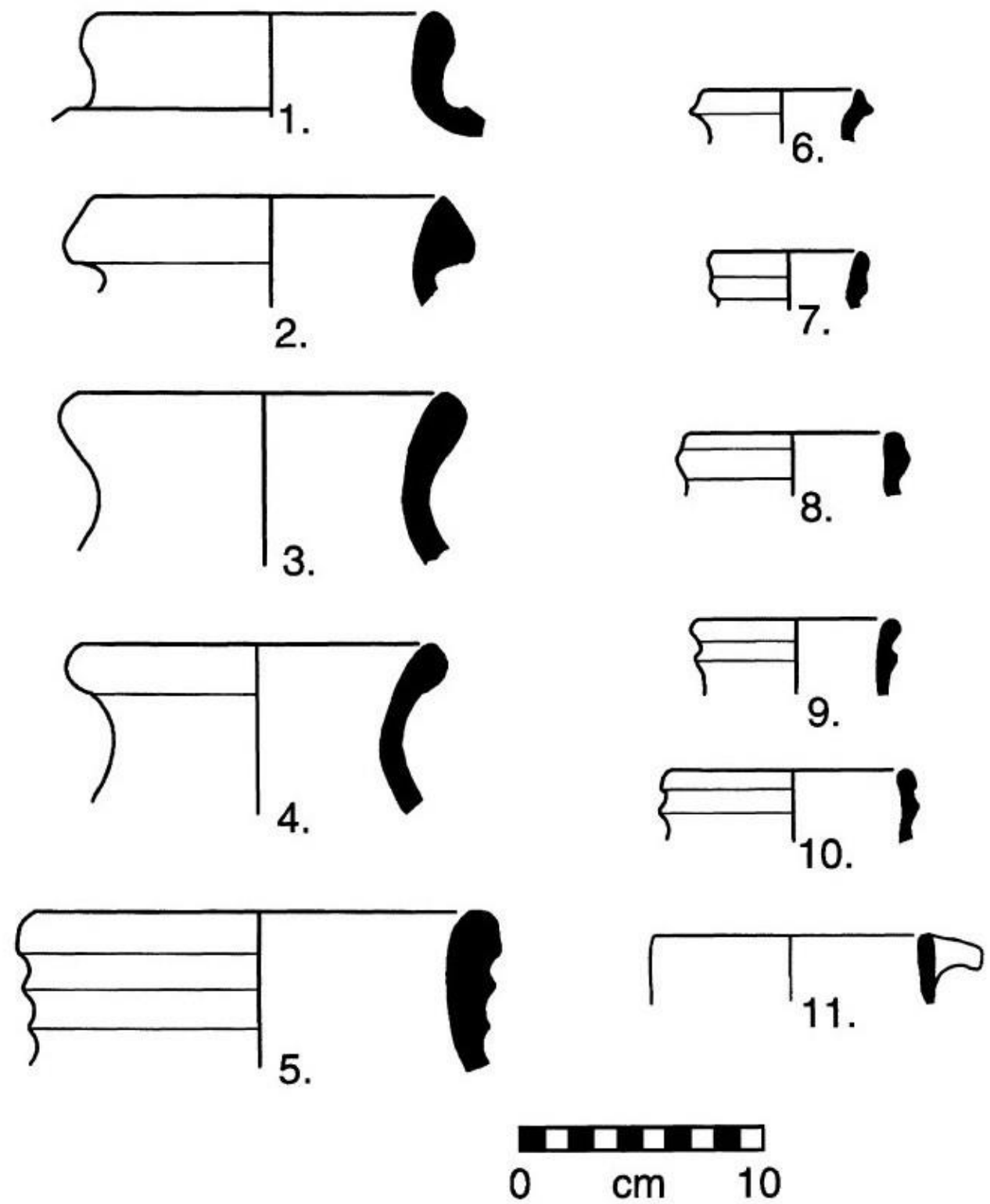

\begin{tabular}{lllll}
\hline \multicolumn{1}{c}{ Number } & \multicolumn{1}{c}{ Context } & \multicolumn{1}{c}{ Fabric } & Surface Treatment \\
\hline 1. 5105.35 .8 & Bldg. 700, Room 705 & 2.5 YR 6/8, light red & Slip: 10 YR 8/3, very pale brown & Storage jar \\
2. Sf.2.16 & Surface & 7.5 YR 6/3, light brown & No & Storage jar \\
3. A1.5.14 & Bldg. 700, Room 704 & 2.5 YR 6/6, light red & No & Storage jar \\
4. A2.6.22 & Bldg. 700, Room 704 & 2.5 YR 6/8, light red & No & Storage jar \\
5. 4J41.12.2 & Bldg. 100, Room 106 & 2.5 YR 6/6, light red & No & Storage jar \\
6. A1.12.5 & Bldg. 700, Room 704 & 2.5 YR 6/3, light reddish brown No & Jar? \\
7. A2.21.1 & Bldg. 700, Room 704 & 2.5 YR 5/8, red & No & Jar? \\
8. A2.27.69 & Bldg. 700, Room 704 & 5 YR 6/4, light reddish brown & No & Jar? \\
9. A2.28.40 & Bldg. 700, Room 704 & 5 YR 6/4, light reddish brown & No & Jar \\
10. 2G87.30.7 & Bldg. 200, Room 204 & 5 YR 6/4, light reddish brown & No & Jar \\
11. 5105.28 .73 & Bldg. 700, Room 705 & 2.5 YR 6/6, light red & No & Jug \\
\hline
\end{tabular}

Figure 45. Iron Age I storage jars, jars, and jugs from Kh. al-Mudayna al-'Aliya (from Routledge 2000: 46). 


\section{Khirbat al-Mudayna al-Mu'arrajah}

Khirbat al-Mudayna al-Mu'arrajah (henceforth KMM; 31¹9'19.3"N

$35^{\circ} 51^{\prime} 46.8$ "E; Figure 46) is a fortified settlement six km northeast of es-Smakiyyah and overlooking the Wadi al-Mujib. It is strategically surrounded by steep drops on all sides except for a small land bridge on the southern end. The site's fortifications include: a casemate wall system surrounding an area of ca. $170 \times 80 \mathrm{~m}$ and a dry moat on the southern side with a tower and gate situated above it. The casemate walls were traced along the perimeter of most of the site and many houses that were attached to it are visible on the surface (Herr 2008c: 1846). Emilio Olavarri excavated the site in 1976 and 1982 and dates its construction to the end of the $13^{\text {th }} /$ beginning of the $12^{\text {th }}$ century B.C. (Olavarri 1977-1978: 143). After a reinterpretation of the pottery, Routledge believes the date of the occupation at $\mathrm{KMM}$ is during the late $11^{\text {th }}-10^{\text {th }}$ centuries B.C. (Routledge 1996: 69). An argument has been made for this site's primary role being that of a military post, as defense for the northeastern area of the Kerak plateau due to its strategic location and poor agricultural situation (Miller et al. 1991: 71). Prior to excavations, Olavarri believed that based on the strategic location, the ruins at KMM hid a citadel that was charged with monitoring and defending the natural border provided by the Wadi el-Mujib (Olavarri 1977-1978: 136).

\section{Casemate Wall System of Khirbat al-Mudayna al-Mu'arrajah}

The casemate wall system at KMM (Figure 47) follows the natural contour of the hill on which it is located. Access to the site was from the south, where the site is at its most narrow and widening farther north (Olavarri 1983: 168). This is where a city gate complex (Figure 48) was excavated along with two towers (T4 and T5) arranged 


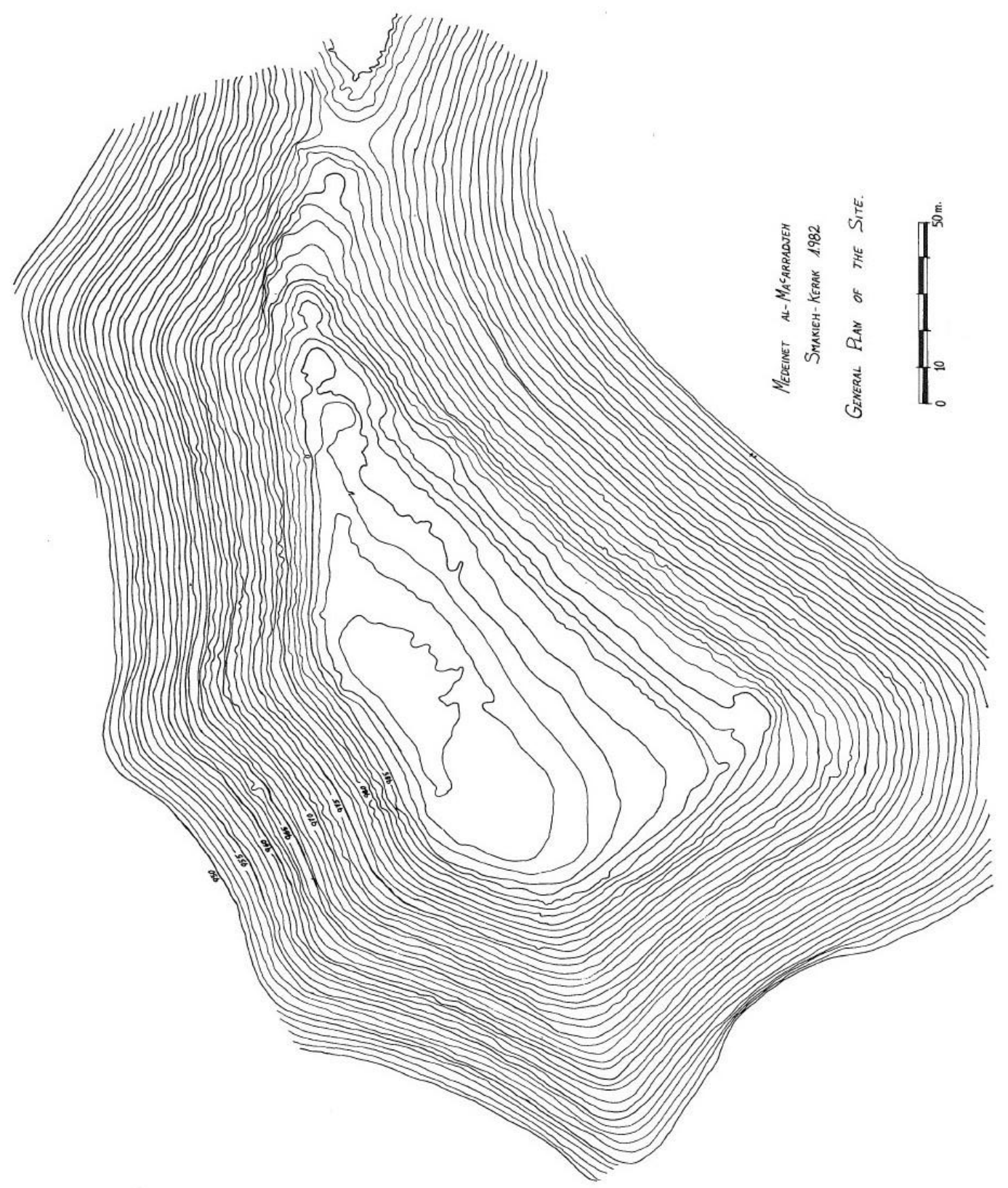

Figure 46. Topography of Kh. al-Mudayna al-Mu'arrajah (from Olavarri 1983: 165). 


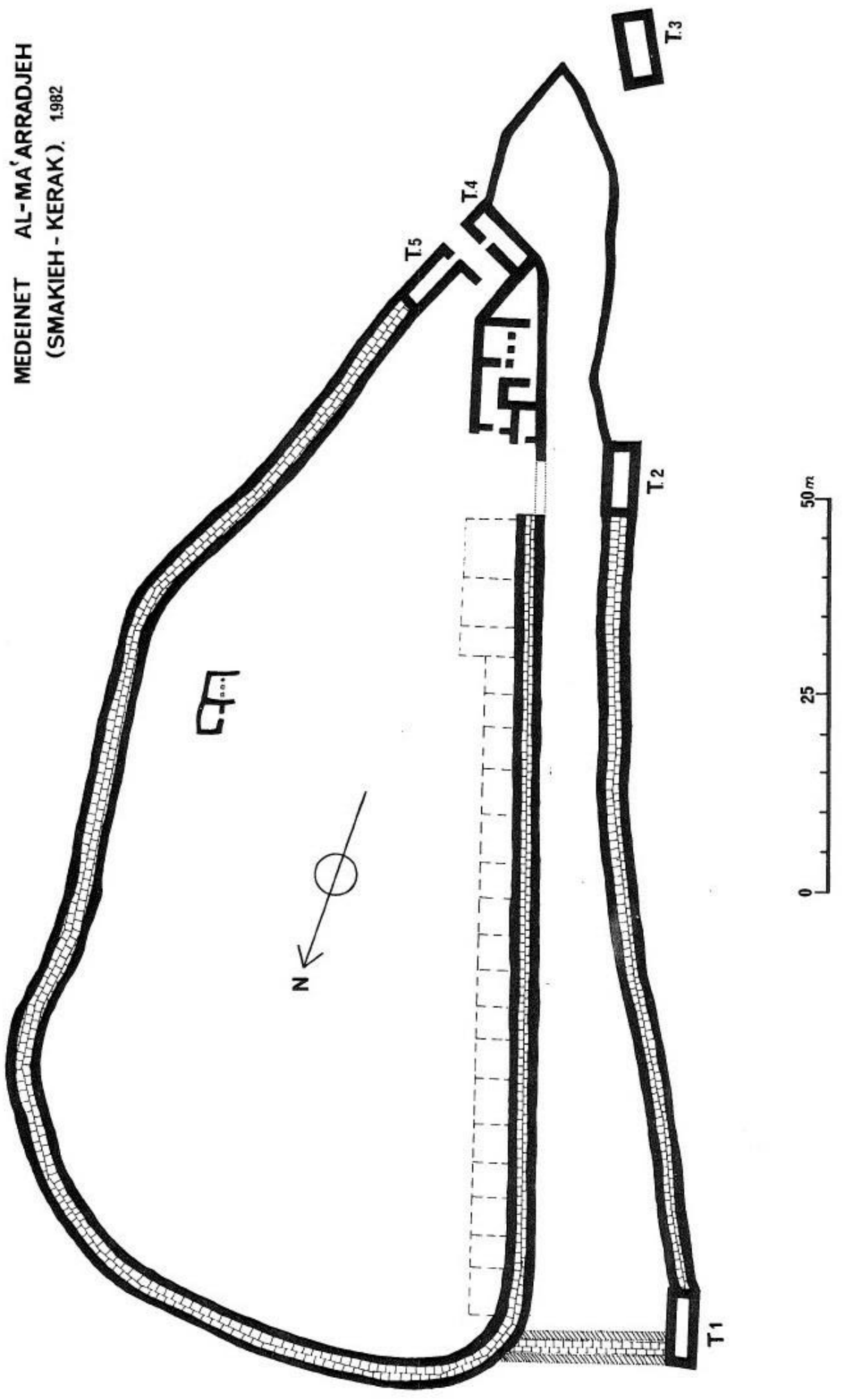

Figure 47. Top plan of Kh. al-Mudayna al-Mu'arrajah (from Olavarri 1983: 169). 


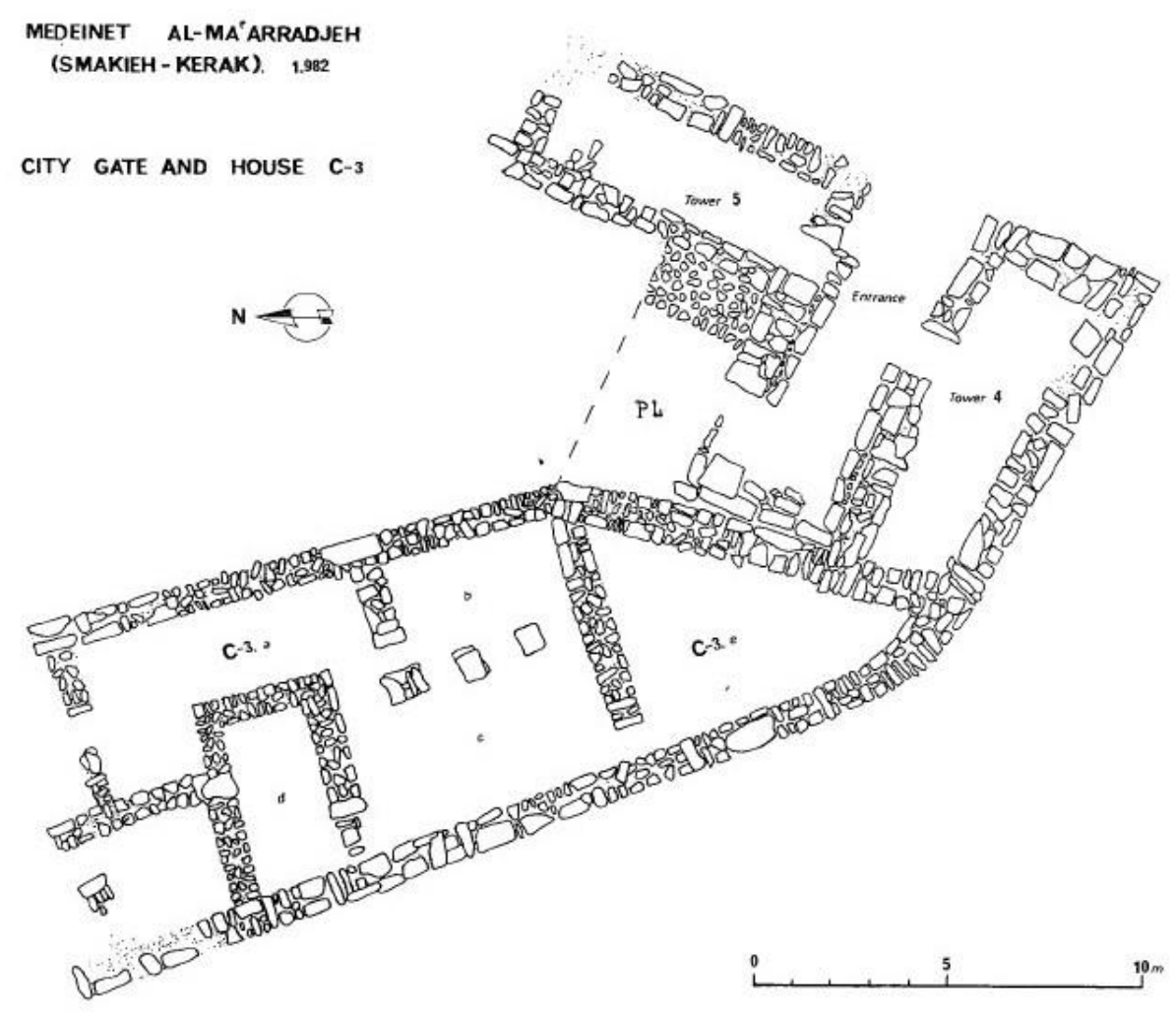

Figure 48. City gate and house at Kh. al-Mudayna al-Mu'arrajah (from Olavarri 1983: 171).

perpendicularly on either side. Tower 4 measured $11.0 \mathrm{~m}$ long by $5.0 \mathrm{~m}$ wide though it has a slightly-deformed rectangular shape. The walls themselves are $1.0 \mathrm{~m}$ thick with a $1.2 \mathrm{~m}$ wide door on the north side (Olavarri 1983: 170). Tower 5 measured $9.0 \mathrm{~m}$ long and $4.0 \mathrm{~m}$ wide matching the width of the eastern wall. The walls are $1.0 \mathrm{~m}$ thick with a door on the south wall. The entrance to the settlement is a $2.5 \mathrm{~m}$ wide by $10.0 \mathrm{~m}$ deep room and located between Towers 4 and 5. No evidence of paving or a threshold was found, rather a beaten earth surface was discovered with a large amount of ashes. Stone benches were built against three walls, to the north, south, and west. The benches rise 
$0.45 \mathrm{~m}$ from the ground. A narrow passage $(1.8 \mathrm{~m}$ wide) on the eastern side of the vestibule allows entrance into the settlement (Olavarri 1983: 173).

The slope is the steepest on the north and east sides where the settlement was defended by a single casemate wall. This wall extended from Tower 5 with a total width between 3.7 and $4.0 \mathrm{~m}$ and with both the inner and outer casemate walls being $1.0 \mathrm{~m}$ thick. Excavations on the eastern and northern casemate walls were never carried out, but most of the architecture was visible above the surface which allowed Olavarri to record the basic dimensions. The settlement had two defensive walls on the western side. The upper casemate wall was a continuation of the casemate wall that was built to the east and north. It ended near the entrance to the settlement where a house abuts the gate complex and Tower 4. This upper casemate wall was measured to be between 3.5 and $3.75 \mathrm{~m}$ wide. House (C-3) was found to be built against the inner wall of this casemate (Olavarri 1983: 168). Olavarri believes this house belonged to an important family based on the quality of the structure and its proximity to the city gate. Most of this house has yet to be excavated and more research needs to be done before conclusions can be made (Olavarri 1983: 173). Based on the architecture visible on the surface and with what has been excavated, Routledge suggested that in addition to houses attached directly to the casemate walls there were also houses built in the center of the settlement. He believes that there was room for between 25 to 35 houses at KMM (Routledge 2004: 99).

The point where the northern casemate wall turns to the south forming the western upper casemate, a short wall continues to the west until it joins with Tower 1 (Figure 49:1). Tower 1 was poorly preserved with a western exterior face measuring 9.25 $\mathrm{m}$ wide by $1.0 \mathrm{~m}$ thick. A lower casemate wall was discovered between Tower 1 and 
Tower 2 (Figure 49:2) to the south (Olavarri 1983: 168). Tower 2 measured $9.75 \mathrm{~m}$ long by $4.75 \mathrm{~m}$ wide with a $1.0 \mathrm{~m}$ thick wall (Olavarri 1983: 170). The lower casemate wall had an irregular layout. It measured between 3.3 to $3.5 \mathrm{~m}$ thick which was thinner than any other part of the casemate wall system at KMM. It was also built with smaller stones which were arranged in an irregular pattern. The space between these two western casemate walls appeared to be devoid of structures. While this area was never excavated, there was no visible architecture unlike what was seen throughout the rest of the site. Olavarri believes that this points to its use as a complementary wall and that its irregular build facilitated its eventual collapse (Olavarri 1983: 168). The point where the lower casemate wall and Tower 2 appear to meet, the wall is simply leaning against the tower rather than becoming part of it. Olavarri suggests that the purpose of these two towers is not defensive or strategic, rather their purpose was to strengthen the lower casemate wall at its most fragile points (Olavarri 1983: 170).

The casemate construction of the lower wall continues from Tower 2 as a single wall line until it connects with Tower 4 near the gate complex. An additional tower (T3; Figure 49:3) was built just 4.5 m outside of this city wall near its most southern tip. It measured $9.75 \mathrm{~m}$ long by $5.0 \mathrm{~m}$ wide with walls that were $1.0 \mathrm{~m}$ thick (Olavarri 1983: 170). The walls of KMM did not show the presence of Cyclopean blocks unlike the architecture at nearby contemporary settlements. The apparatus of the walls was quite rough with neither facing nor headers and without a continuous foundation (Olavarri 1983: 168). 


\section{Ceramics of Khirbat al-Mudayna al-Mu'arrajah}

The majority of the ceramic types and forms found at KMM were found in the occupation layers with very few examples from destruction layers. The ceramics themselves are uniform, yet of poor quality. According to Olavarri, the pottery is attributed to a single occupation during the early Iron Age I, in the $12^{\text {th }}$ and $11^{\text {th }}$ centuries B.C. Large storage jars and kraters were the most prominent of the pottery forms found, with fewer forms of pots, bowls, small jars and jugs. No lamp fragments were recovered, however, Olavarri presumes this is because they had not excavated house floors, where lamps would be likely to be found. Carinated bowls (Figure 50:1, 3), rounded bowls (Figure 50:2) and cooking pots (Figure 50:4-5) were present. A few fragments of the pithoi, labeled as 'collared rim jars,' were found (Figure 50:7-12).

Chronologically, the oldest fragment (Figure 50:8) was found in the buttress against the western wall of Tower 5 and may be used to date the construction of the settlement. The latest fragments (Figures 50:7, 9-11) were all found in the occupation or destruction layers, potentially dating the site's abandonment or destruction. Krater forms (Figure 50:13-16) which can be dated to the LB-Iron I transition period are also present. Based on the ceramics, Olavarri concludes that KMM was built at the beginning of the 12th century B.C. (or possibly the end of the 13th century) and then abandoned or destroyed around 1075-1050 B.C. He based these conclusions on the pithoi forms and the absence of polished ceramics (Olavarri 1983: 174-78). 

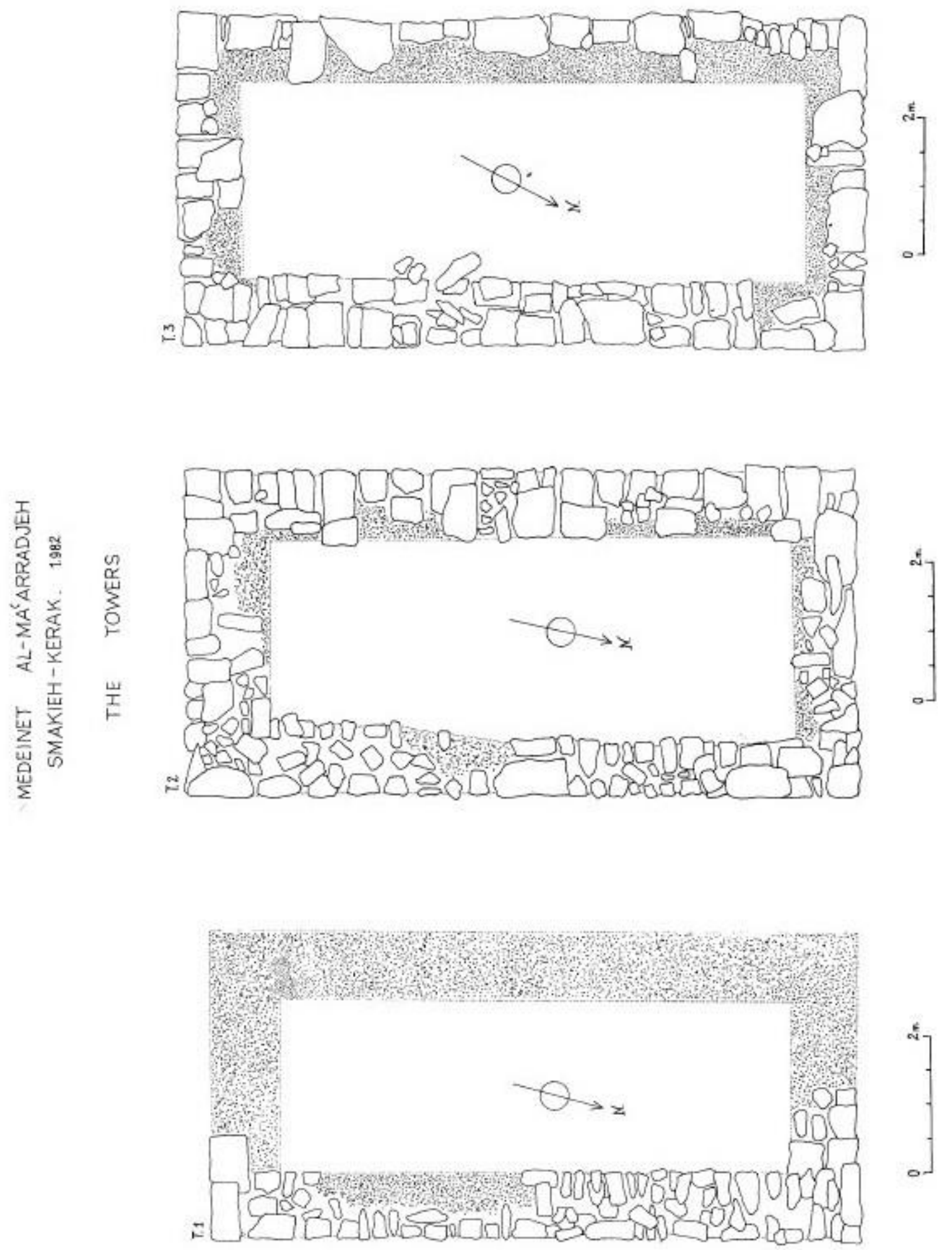

Figure 49. Towers 1-3 at Kh. al-Mudayna al-Mu'arrajah (from Olavarri 1983: 172). 

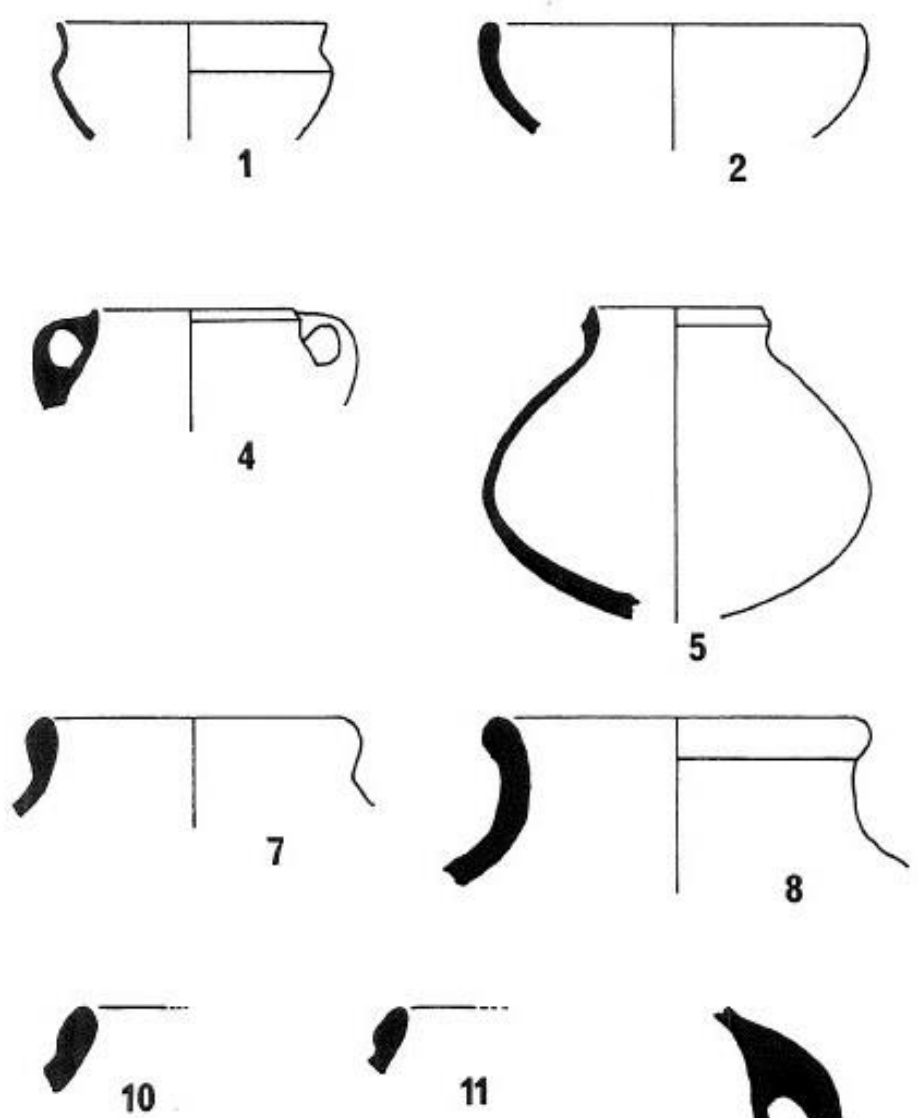

10
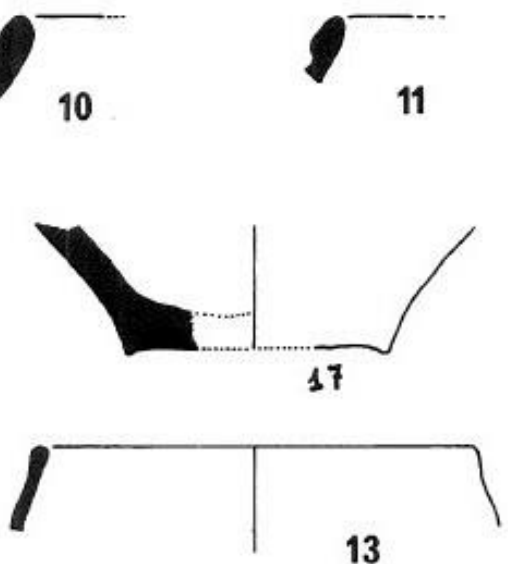

13

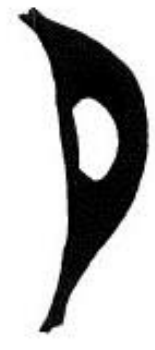

12
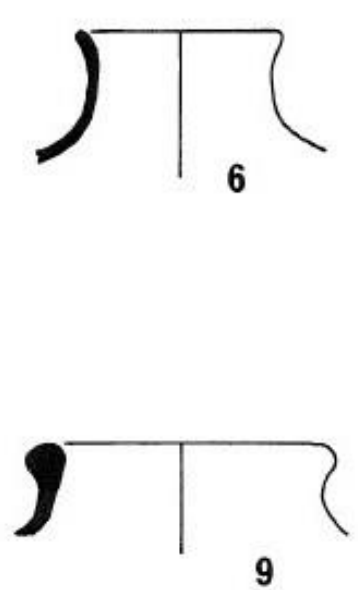

3

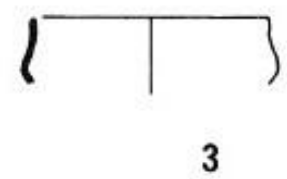

9
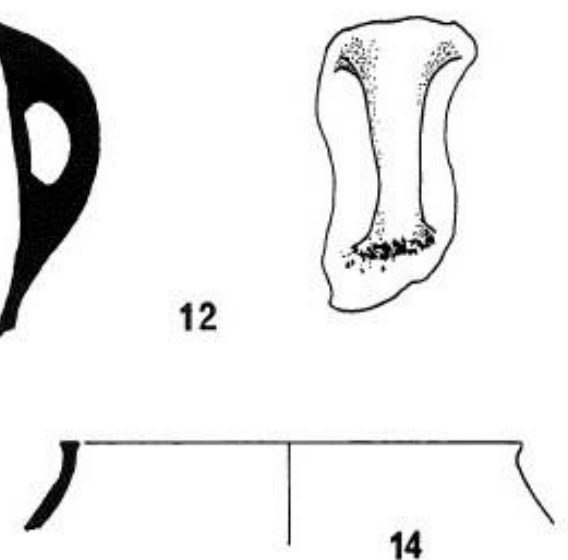
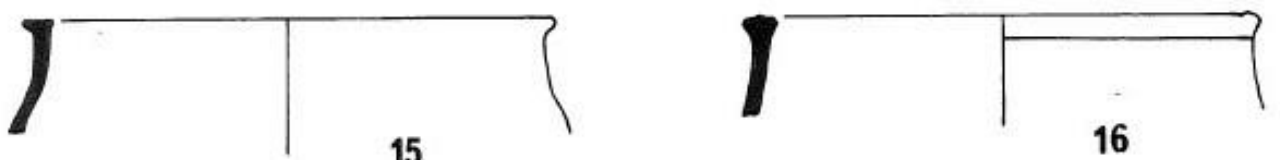

15

\section{6}

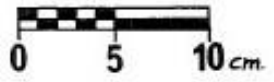

Figure 50. Iron Age I Pottery Assemblage from Kh. al-Mudayna al-Mu'arrajah (from Olavarri 1983: 176). 


\section{Khirbat al-Lahun}

Khirbat al-Lahun $\left(31^{\circ} 27^{\prime} 34.8^{\prime \prime} \mathrm{N} 35^{\circ} 50^{\prime} 54.1^{\prime \prime E}\right)$ is situated on a plateau overlooking the Wadi al-Mujib. Kh. al-Lahun was excavated from 1978 until 2000 by the Belgian Committee of Excavations and was directed by Paul Naster and later Denyse Homes-Fredericq. The history of the site starts in prehistoric times and goes through periods of occupation and abandonment until the Islamic period. The people at Kh. alLahun choose to build their settlements so that they were scattered around four acres of the plateau with each location chosen to fit the needs of the people during that period (Figure 51) instead of rebuilding or reusing older architecture. In the southwestern corner of Kh. al-Lahun, evidence of a LB-Early Iron Age settlement was uncovered.

A casemate wall system (Figure 52) is believed to have surrounded the LB-Early Iron Age settlement. However, evidence has been excavated in only the northern, western, and southern limits of the settlement (Herr 2008a: 1845). They encompass an area of ca. 1700 square meters. The casemate wall system is dated to the transitional LBEarly Iron Age period (van der Steen 1996: 55). Parts of the casemate wall system were specifically built for defense, while many of the peripheral houses were integrated into the casemate with some of the rooms being located inside the casemate walls (HomesFredericq 1993: 470). The casemate walls were built up against buildings or built freestanding in other areas of Kh. al-Lahun. A total of 15 casemate rooms were excavated around the settlement with a continuous line between 16 and $19 \mathrm{~m}$ uncovered. The outer wall is between 0.70 and $0.80 \mathrm{~m}$ wide, the inner wall is approx. $0.75 \mathrm{~m}$, and the two walls are 1.80 to $2.20 \mathrm{~m}$ apart from each other (Homes-Fredericq 1992: 188; Swinnen 2009: 30). Archaeologists discovered kilns, ovens, grain silos, grinding stones, and other 


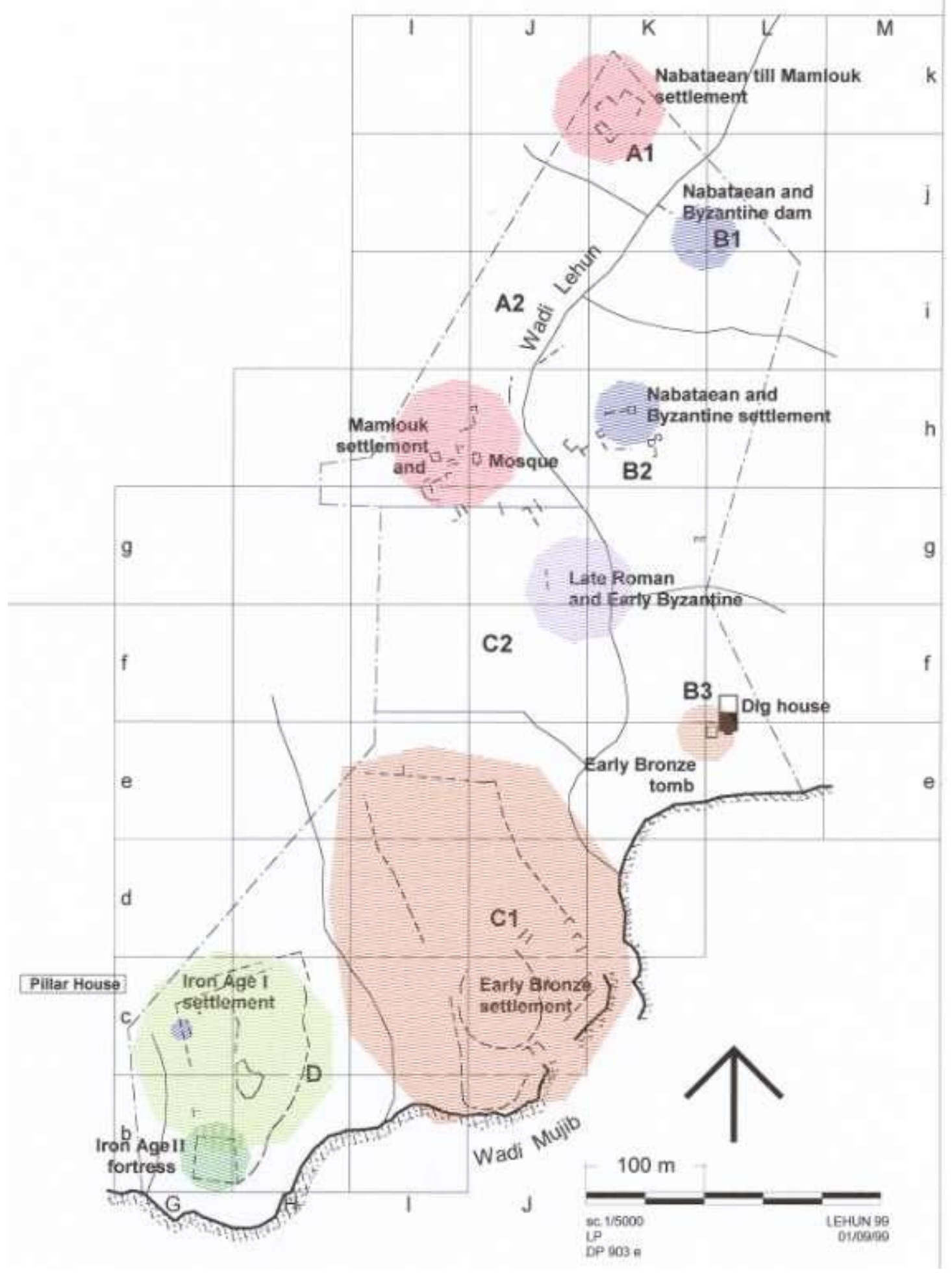

Figure 51. Site of Kh. al-Lahun (from Swinnen 2009: 31). 


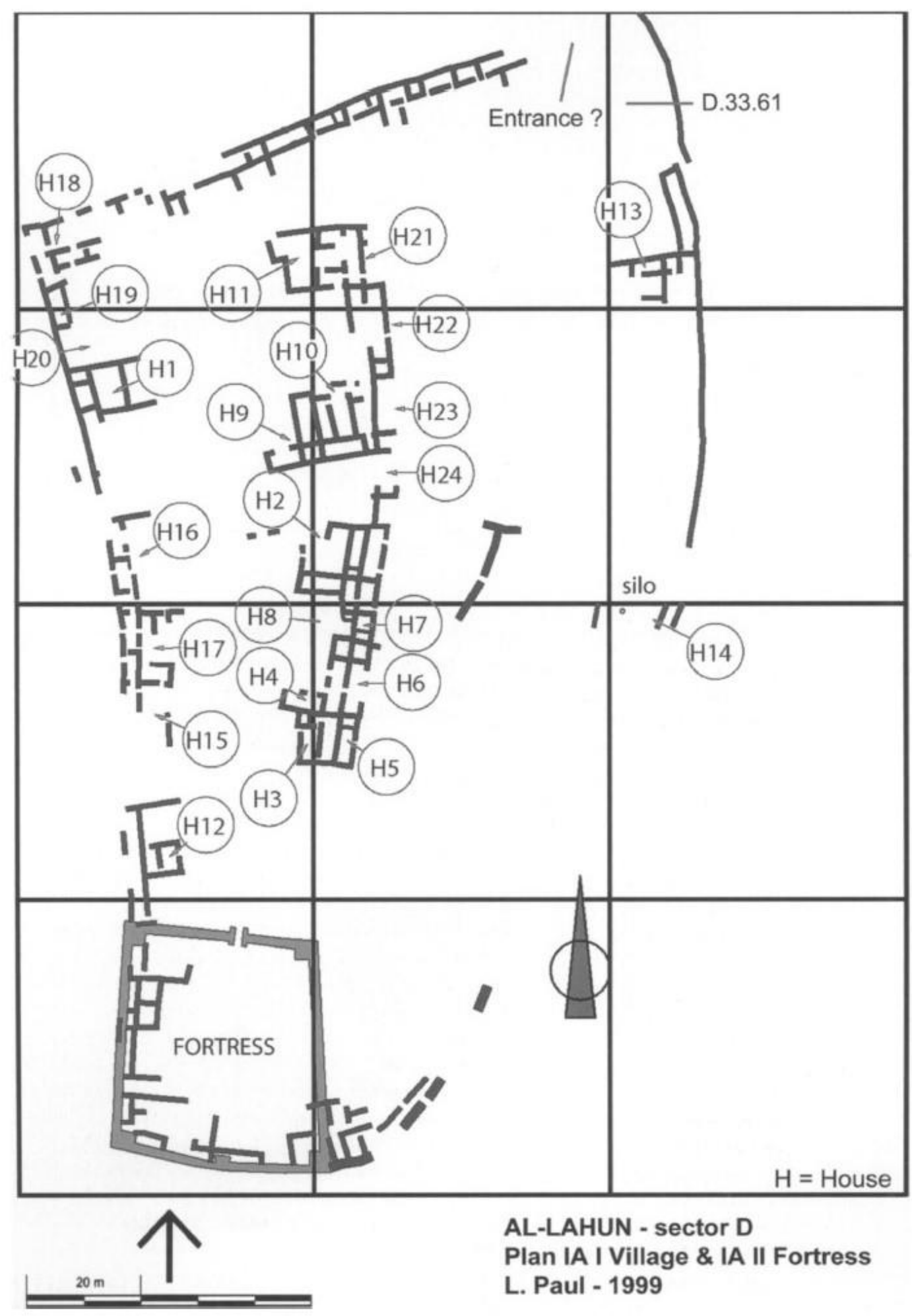

Figure 52. Top play of Iron Age settlement and fortress at Kh. al-Lahun (from Swinnen 2009: 32). 
agricultural tools within the rooms suggesting that they were used as living and storage quarters by an agricultural population (van der Steen 1996: 55). The casemate rooms to the north show evidence of being reinforced during wartime with large stones. Several breaks in the casemate walls on the eastern side also indicate attacks on the settlement (Homes-Fredericq 1993: 470). Towers were also found around this settlement which were built in the corners of the wall. However, where most towers would be built outside the wall, the topography of the site forced them to be placed inside the walls (Herr 1997: 124).

The casemate wall system at Kh. al-Lahun is extremely difficult for archaeologists to date. The original excavators gave it an LB date, while a reexamination of the pottery and material finds that are from the same phase as the casemate wall system has discovered that those finds actually date to the early Iron Age I (Herr 2008a: 1845). Most archaeologists have agreed that this site fits in what they call the transitional LB-early Iron Age period. Most admit that while we cannot determine the exact period in which the walls fit it was built no earlier than the late $12^{\text {th }}$ century B.C. (Routledge 2000: 47). Based on the strengthening of the walls to the north and the evidence of destruction along the casemate walls there appears to have been a significant threat to the settlement at Kh. al-Lahun. However, the walls and towers were not built particularly thick or very large. Perhaps they lacked the time or material to build a proper defensive wall or they believed an attack to be unlikely and were caught unaware. 


\section{CHAPTER 5}

\section{COMPARISON BETWEEN SIMILAR CASEMATE}

\section{WALL STRUCTURES}

Each site in Transjordan that has an Iron Age I casemate wall system appears to have many similarities (Figure 53) and a few unique aspects. Each site is essentially a one-period site with the settlement at Kh. Safra existing into the Iron Age II and with later squatter remains. Kh. al-Lahun also has a unique layout, but the part of the settlement, of which the casemate wall surrounds, was primarily an Iron Age I settlement with an Iron Age II fortress in the southwest corner. Each casemate wall system is enclosing a settlement, but there is some variance is size. The settlement at Kh. al-Lahun is much smaller than the other sites at only 1700 sq. m. KMA is the largest by far with the casemate wall enclosing an area of ca. 375 x 70 m. Kh. Safra, Kh. al-Ma'mariyah, and KMM are similar in size with only a ca. 3,000 sq. $\mathrm{m}$ difference between them.

Casemate wall systems were built in a similar fashion at each site. The outer wall at Kh. al-Lahun $(0.70-0.80 \mathrm{~m})$ and the inner wall at Kh. Safra $(0.50-0.80 \mathrm{~m})$ being slightly thinner than those at Kh. al-Ma'mariyah (1.2 m), KMA (0.8-1.2 m), and KMM $(1.0 \mathrm{~m})$. The width of the casemate walls does not seem to correlate directly to the size of the casemate rooms. The smallest rooms are found at KMM (ca. $1.75 \mathrm{~m}$ wide) despite having $1.0 \mathrm{~m}$ wide outer and inner walls. The casemate rooms at Kh. al-Lahun $(1.8-2.0 \mathrm{~m}$ 


\begin{tabular}{|c|c|c|c|c|c|c|c|c|c|c|}
\hline 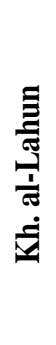 & 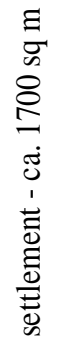 & 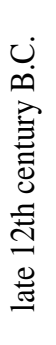 & $\begin{array}{l}\Xi \\
0 \\
0 \\
0 \\
0 \\
\vdots \\
0 \\
0\end{array}$ & 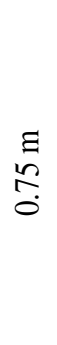 & $\stackrel{\overbrace{}}{\stackrel{⿹}{~}}$ & 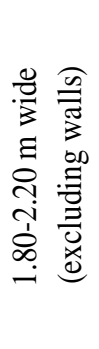 & 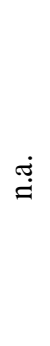 & $\cong$ & 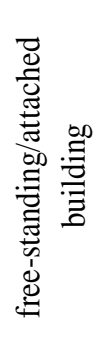 & 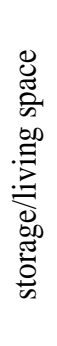 \\
\hline$\sum_{\Sigma}$ & 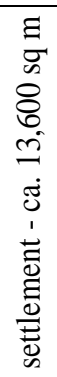 & 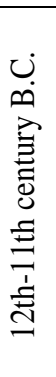 & $\begin{array}{l}\Xi \\
0 \\
ٍ\end{array}$ & $\begin{array}{l}\Xi \\
ٍ\end{array}$ & $\stackrel{\overbrace{}]}{=}$ & 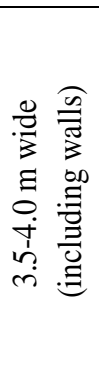 & 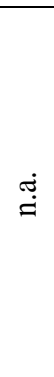 & 0 & 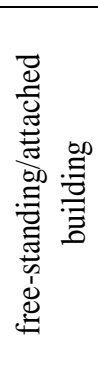 & 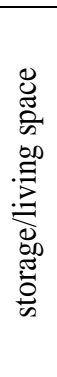 \\
\hline$\underset{1}{\$}$ & 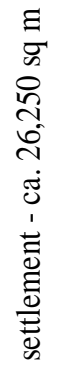 & 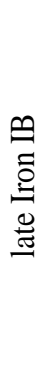 & 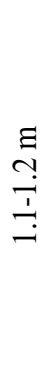 & $\frac{\Xi}{\Xi}$ & 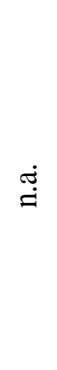 & 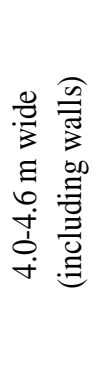 & 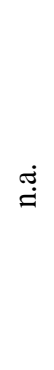 & 인 & 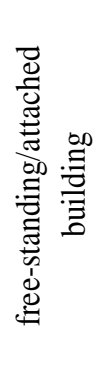 & 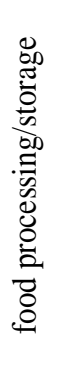 \\
\hline 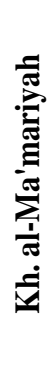 & 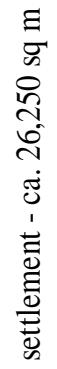 & 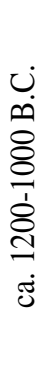 & $\begin{array}{c}\Xi \\
\stackrel{\Xi}{ }\end{array}$ & $\stackrel{\text { İ }}{=}$ & 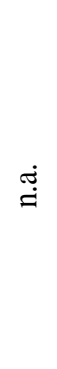 & 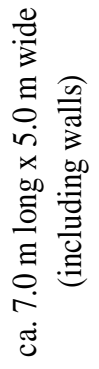 & $\begin{array}{l}\frac{0}{0} \\
\vdots \\
\vdots \\
0 \\
\end{array}$ & in & 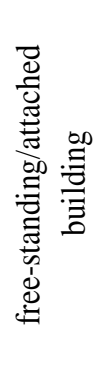 & 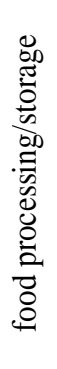 \\
\hline 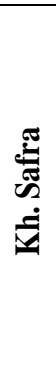 & 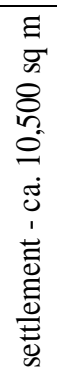 & 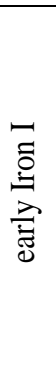 & 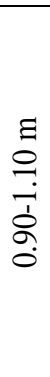 & $\begin{array}{l}\Xi \\
0 \\
\infty \\
0 \\
0 \\
0 \\
0 \\
0\end{array}$ & 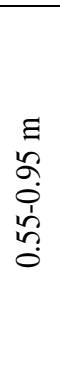 & 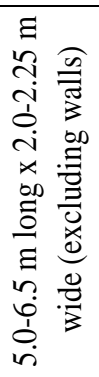 & 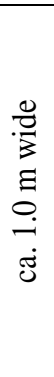 & $\infty$ & 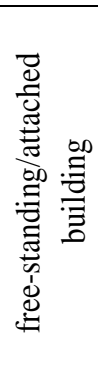 & 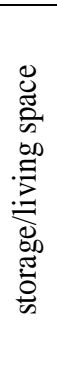 \\
\hline & 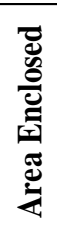 & 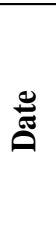 & 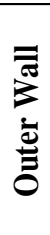 & 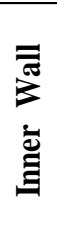 & 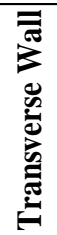 & 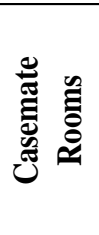 & 产 & 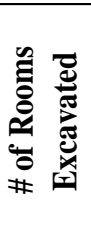 & 产 & 总 \\
\hline
\end{tabular}

Figure 53. Comparison of the casemate wall systems discussed in this paper. 
wide), Kh. Safra (2.0-2.25 m wide), and KMA (ca. $2.25 \mathrm{~m}$ wide) are similar in size, while Kh. al-Ma'mariyah has the widest rooms (ca. $2.8 \mathrm{~m}$ wide). The walls were built freestanding with buildings incorporating some of the casemate rooms in most cases. At KMM, none of the excavated buildings were attached to the casemate wall system; however, enough of the architecture was visible on the surface for the excavators to determine that there were buildings which were attached and incorporated the casemate walls. None of the casemate walls in this study have shown evidence of being buttressed or battered. The casemate rooms at each site were used for very similar purposes. Each site shows evidence that the rooms were used for storage. The rooms at Kh. Safra, KMM, and Kh. al-Lahun were also being used as living space and the rooms at Kh. alMa'mariyah and KMA showed evidence that they were also used for food processing. The generally accepted conclusion regarding the function of the sites of Kh. alMa'mariyah, KMA, KMM, and Kh. al-Lahun is that they were not built for military purposes. Rather, the sites presented evidence suggesting they served more as agropastoral settlements. However, arguments have been made that KMM served as a military post due to its strategic location.

One interesting parallel that was found in this research can be seen when comparing the architecture of Building 2 at Kh. Safra (Figure 54) with Building 400 at KMA (Figure 55). The northern portion of Building 2 at Kh. Safra is not yet completely excavated, the architecture that is visible suggests a similarity to that of Building 400 at KMA.

The similarities in form and function of the casemate wall system of Kh. Safra and those at Kh. al-Ma'mariyah, KMA, KMM, and Kh. al-Lahun is interesting. They 


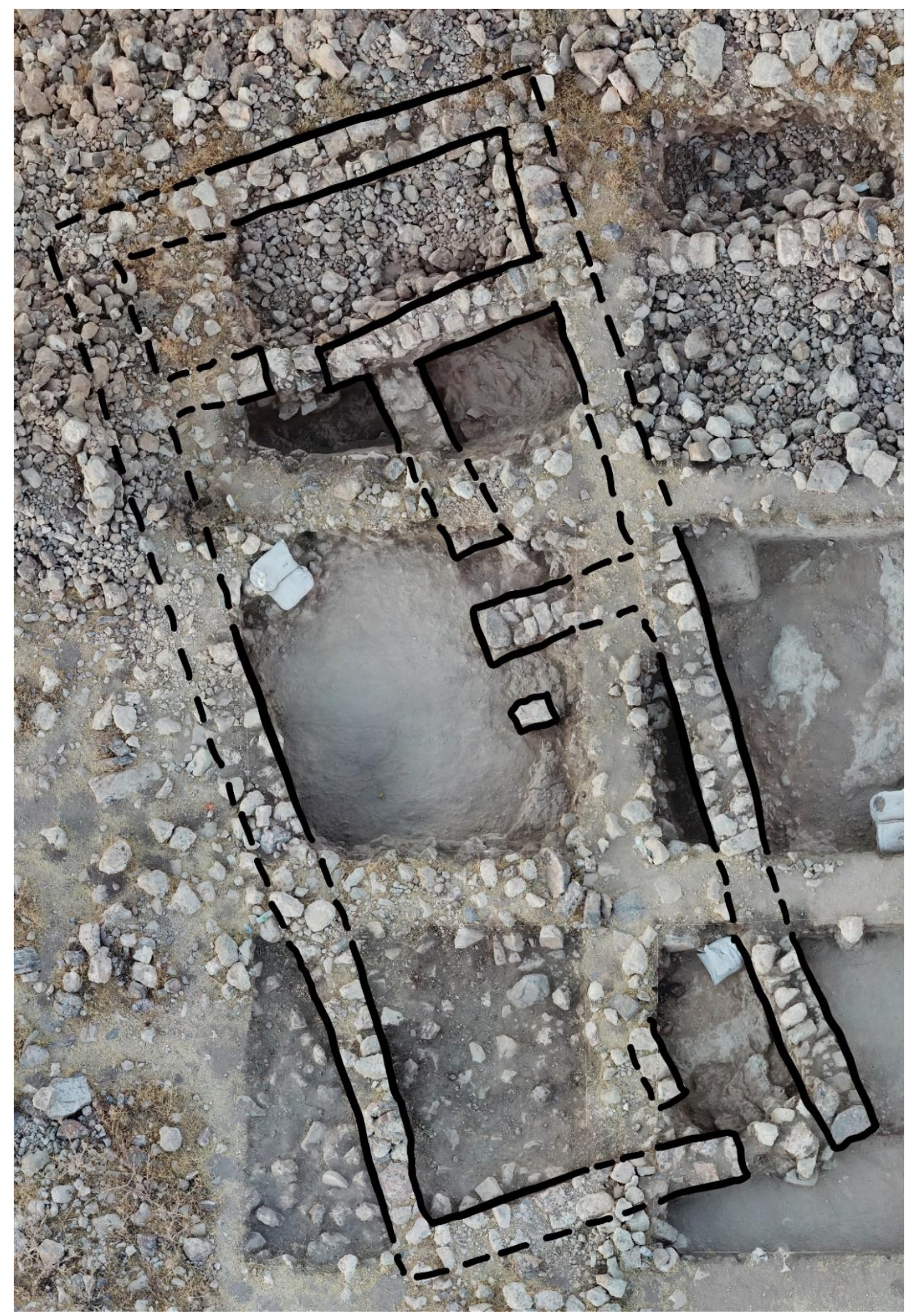

Figure 54. Building 2, Field B, Kh. Safra (modified from Gregor, Ray, and Moody: fig. $5)$. 


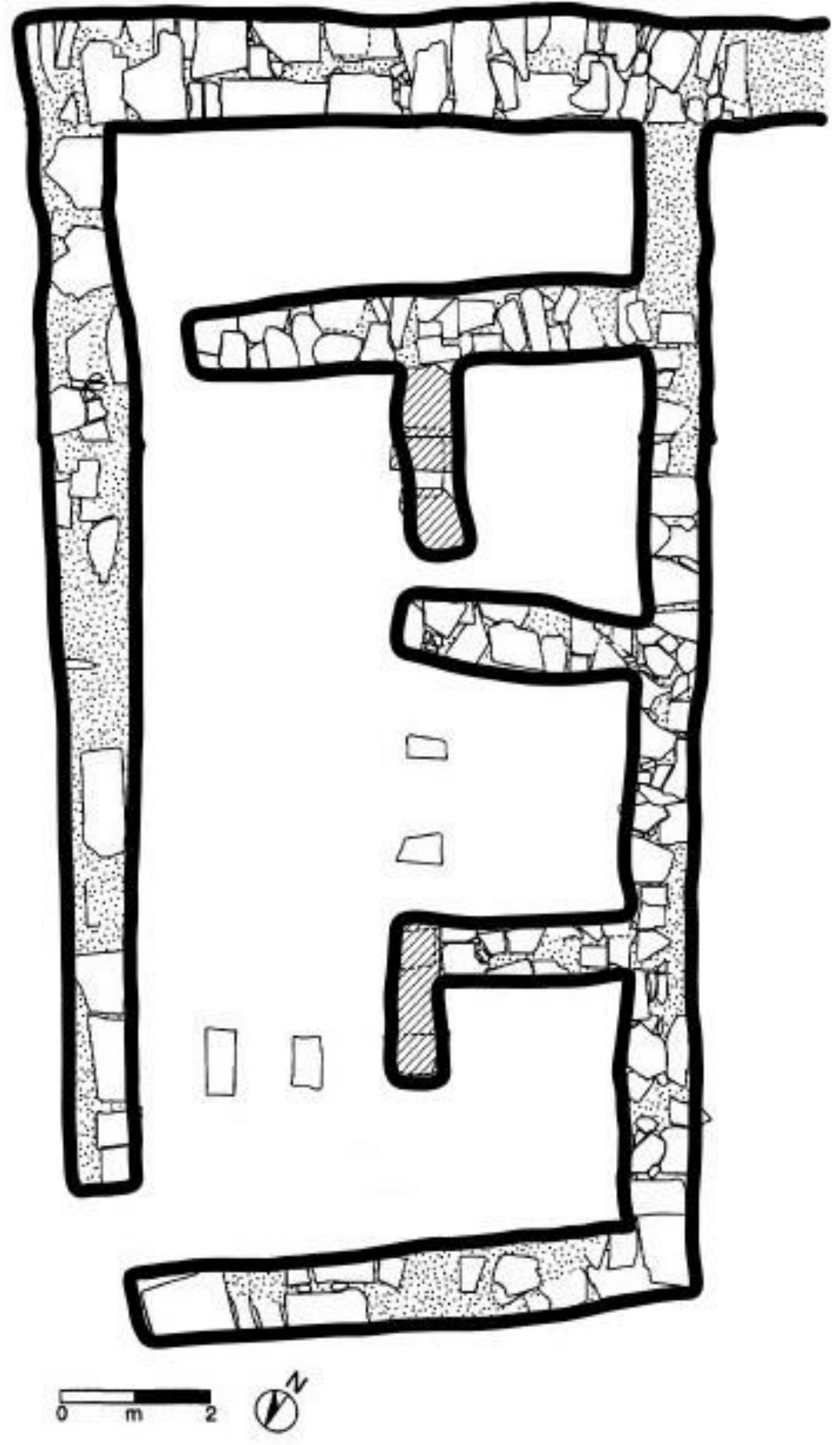

Figure 55. Building 400 at Kh. al-Mudayna al-'Aliya (modified from Routledge 2000: $51)$. 
could indicate that each settlement had a similar purpose, possibly that of a quick and easy defensive system for a community focused on agriculture and pastoralism. The architectural similarities could also indicate that there was a widely accepted way of building a casemate wall system that the builders at each site followed closely. Similarities between Kh. al-Ma'mariyah, KMA, KMM, and Kh. al-Lahun are easy to understand based on the proximity of these sites, which are all located on the Karak Plateau and similar topography. However, Kh. Safra is farther north, located in a different region of Transjordan, so the reason behind the similarities between this site and those on the Karak Plateau is harder to explain. 


\section{CONCLUSION}

The Iron Age I casemate wall systems in Transjordan have generally not been excavated enough at this point. Kh. al-Lahun (with 15 excavated casemate rooms) and KMA (with ten excavated casemate rooms) are by far the most extensively excavated, however, neither casemate wall system has received a proper focus on publication. Kh. Safra, having had only two seasons of excavation, has uncovered at least part of eight casemate rooms. Kh. al-Ma'mariyah (with five excavated casemate rooms) and KMM (with no excavated casemate rooms and only measurements taken from what is visible on the surface) have been excavated much less extensively, but also suffer from a lack of publication of the available data. A more extensive comparison is pending until further excavations are conducted and comprehensive publications are made available. Despite this, the architectural similarities between these sites is striking and cannot be chalked up to mere coincidence.

Excavations at Kh. Safra are still ongoing and there is much that may yet be discovered regarding its function and its relationship to the surrounding region. Future excavations may reveal this purpose and potentially reveal its apparent connection to the casemate wall systems at Kh. al-Ma'mariyah, KMA, KMM, and Kh. al-Lahun. Current plans include revealing the connection between the casemate wall system and the gate system as well as further articulating the relationship between the casemate wall system and the buildings to which they are incorporated. 


\section{REFERENCE LIST}

Albright, W. F.

1960

Badawy, A.

1966

Bloch-Smith, E.

2015

A Stratified Account of Jephthah's Negotiations and Battle: Judges 11:12-33 from an Archaeological Perspective. Journal of Biblical Literature 134.2: 291-311.

Brown, S. H.

2010

A Reevaluation of Iron Age Fortified Sites on the Eastern Kerak Plateau. Unpublished MA Thesis, North Carolina State University.

Burke, A. A. 2008

Walled Up To Heaven: The Evolution of Middle Bronze Age Fortification Strategies in the Levant. Studies in the Archaeology and History of the Levant 4. Winona Lake, IN: Eisenbrauns.

David, C. B. 2017

The Mudayna Sites of the Arnon Tributaries: "Midian Alongside Moab"? Antigua Oriente 15: 149-74.

Dever, W. G. 1974

The MB IIC Stratification in the Northwest Gate Area at Shechem. Bulletin of the American Schools of Oriental Research 216: 31-52.

Eph'al, I.
2009

The City Besieged: Siege and Its Manifestations in the Ancient Near East. Brill: Boston.

Farahani, A.; Porter, B. W.; Huynh, H.; and Routledge, B.

2016

Mudayna al-'Aliya (Jordan): A Paleoethnobotanical Approach. Annual of the American Schools of Oriental Research 69: 27-89. 
Fischer, P. M.

1997

1998

2008

Gonen, R.

1984
Tall Abu al-Kharaz: The Swedish Jordan Expedition 1995-1996, Sixth and Seventh Season Preliminary Excavation Report. Annual of the Department of Antiquities of Jordan 41: 129-44.

Tall Abu al-Kharaz: The Swedish Jordan Expedition 1997, Eighth Season Preliminary Excavation Report. Annual of the Department of Antiquities of Jordan 42: 213-23.

Tell Abu al-Kharaz: A Bead in the Jordan Valley. Near Eastern Archaeology 71.4: 196-213.

Urban Canaan in the Late Bronze Period. Bulletin of the American Schools of Oriental Research 253: 61-73.

Gophna, R.

1993

Far'ah, Tell el- (South). Pp. 441-44 in vol. 2 of The New

Encyclopedia of Archaeological Excavations in the Holy Land, ed. E. Stern. Jerusalem: Israel Exploration Society.

Gregor, P. Z.; Ray, P. J.; Gane, C. E.; Broy, T.; and Moody, J.

In Press

Preliminary Report on the 2018 Season of Excavations at Khirbat Safra. Annual of the Department of Antiquities.

Gregor, P. Z.; Ray, P. J.; and Moody, J.

In Press

Preliminary Report on the 2019 Season of Excavations at Khirbat Safra. Annual of the Department of Antiquities.

Haser, J. 2007

Gadara Region Project. Pp. 526-30 in Archaeology in Jordan, 2006 Season, American Journal of Archaeology 111, eds. S. J. Savage, D. R. Keller. and S. H. Savage.

Herr, L. G.

1997

Archaeological Sources for the History of Palestine: The Iron Age II Period: Emerging Nations. Biblical Archaeologist 60.3: 114-83.

2008a Lehun, Khirbet el-. Pp. 1845 in vol 5. of The New Encyclopedia of Archaeological Excavations in the Holy Land, ed. E. Stern.

Washington, DC: Biblical Archaeology Society.

2008b Mudeina el-'Aliya, Khirbet el-. Pp. 1846 in vol 5. of The New

Encyclopedia of Archaeological Excavations in the Holy Land, ed. E. Stern. Washington, DC: Biblical Archaeology Society. 
2008c Mudeina el-Mu'arraja, Khirbet el-. Pp. 1846 in vol 5. of The New Encyclopedia of Archaeological Excavations in the Holy Land, ed. E. Stern. Washington, DC: Biblical Archaeology Society.

Herzog, Z.

1992

Settlement and Fortification Planning in the Iron Age. Pp. 231-74 in The Architecture of Ancient Israel, eds. A. Kempinski and R. Reich. Jerusalem: Israel Exploration Society.

Homes-Fredericq, D. 1992

Late Bronze and Iron Age Evidence from Lehun in Moab. Pp. 187202 in Early Edom and Moab: The Beginning of the Iron Age in Southern Jordan, ed. P. Bienkowski. Sheffield: J.R. Collis Publications.

1993 El-Lehun. Pp. 468-71 in Archaeology in Jordan, American Journal of Archaeology 97.3, eds. B. de Vries and P. Bikai.

Kempinski, A. 1992a

Fortifications, Public Buildings, and Town Planning in the Early Bronze Age. Pp. 68-80 in The Architecture of Ancient Israel, eds. A. Kempinski and R. Reich. Jerusalem: Israel Exploration Society.

1992b Middle and Late Bronze Age Fortifications. Pp. 127-42 in The Architecture of Ancient Israel, eds. A. Kempinski and R. Reich. Jerusalem: Israel Exploration Society.

Kern, P. B.

1999

Ancient Siege Warfare. Bloomington, IN: Indiana University Press.

$2004 \quad$ Under Siege! Archaeology Odyssey 7.1: 40.

Lapp, N.

1976

Casemate Walls in Palestine and the Late Iron II Casemate at Tell el-Ful (Gibeah). Bulletin of the American Schools of Oriental Research 223: 25-42.

Lapp, P. 1969

The 1968 Excavations at Tell Ta'annek. Bulletin of the American Schools of Oriental Research 195: 2-49.

Miller, J. M. 1991

The Sites. Pp. 23-167 in Archaeological Survey of the Kerak Plateau, ed. J. M. Miller. Atlanta, GA: Scholars Press. 
Ninow, F.

$2002 \mathrm{a}$

$2002 b$

$2004 a$

$2004 b$

$2006 b$

2007

2008

Olavarri, E.

1983
1977-1978

In Search of the "City Which is in the Middle of the Valley." Andrews University Seminary Studies 40.1: 125-29.

Preliminary Report on the Wadi Ash-Shkafia Survey 2001. Annual of the Department of Antiquities of Jordan 46: 151-56.

Khirbat al-Mamariya. Pp. 436-37 in Archaeology in Jordan 2003 Season, American Journal of Archaeology 108, eds. S. J. Savage, K. A. Zamora, and D. R. Keller.

First Soundings at Khirbat al-Mu'mmariyya in the Greater Wadi al-Mujib Area. Annual of the Department of Antiquities of Jordan 48: 257-66.

Khirbat al-Mamariya. Pp. 475-76 in Archaeology in Jordan 2005 Season, American Journal of Archaeology 110, eds. S. J. Savage and D. R. Keller.

The 2005 Soundings at Khirbat al-Mu'mmariyya in the Greater Wadi al-Mujib Area. Annual of the Department of Antiquities of Jordan 50: 147-55.

Faith in Situ: Digging God Out From the Tell. Paper presented at the $35^{\text {th }}$ International Faith and Learning Seminar, Hong Kong Adventist College.

The 2007 Season of the Wadi ash-Shuqayfat Survey in the Great Wadi al-Mujib Area. Annual of the Department of Antiquities of Jordan 52: 81-89.

Sondeo Arqueologico en Khirbet Medeineh junto a Smakieh (Jordania). Annual of the Department of Antiquities of Jordan 22: 136-49.

La Campagne de Fouilles 1982 A Khirbet Medeinet al-Mu'arradjeh Pres de Smakieh (Kerak). Annual of the Department of Antiquities of Jordan 27: 165-78.

Routledge, B. 1996
Intermittent Agriculture and the Political Economy of Iron Age Moab. Unpublished Ph.D. Dissertation, University of Toronto. 
2000 Seeing Through Walls: Interpreting Iron Age I Architecture at Khirbat al-Mudayna al-'Aliya. Bulletin of the American Schools of Oriental Research 319: 37-70.

2004 Moab in the Iron Age: Hegemony, Polity, Archaeology. Philadelphia, PA: University of Pennsylvania Press.

Routledge, B., and Porter, B.

2007

A Place In-Between: Khirbat al-Mudayna al-'Aliya in the Early Iron Age. Pp 323-329 in Crossing Jordan: North American Contributions to the Archaeology of Jordan, eds. T. E. Levy, P. M. Michele Daviau, R. W. Younker, and M. Shaer. London: Equinox Publishing.

Safra Excavation Archives. Records of the 2018-2019 Seasons. Berrien Springs, MI: Andrews University/Institute of Archaeology.

Seevers, B.

2013

Warfare in the Old Testament: The Organization, Weapons, and Tactics of Ancient Near Eastern Armies. Grand Rapids, MI: Kregal Publications.

Swinnen, I. M.

The Iron Age I Settlement and Its Residential Houses at al-Lahun in Moab, Jordan. Bulletin of the American Schools of Oriental Research 354: 29-53.

van der Steen, E. J. 1996

The Central East Jordan Valley in the Late Bronze and Early Iron Ages. Bulletin of the American Schools of Oriental Research 302: 51-74.

Viewegerta, D. and Haser, J.

2007 Tall Zira'a: Five Thousand Years of Palestinian History on a Single-Settlement Mound. Near Eastern Archaeology 70.3: 14767.

Yadin, $Y$.

1963 The Art of Warfare in Biblical Lands in Light of Archaeological Discovery. Trans. M. Pearlman, from Hebrew. London: Weidenfeld and Nicolson. 
Yadin, Y.; Aharoni, Y.; Amiran, R.; Ben-Tor, A.; Dothan, M.; Dothan, T.; Dunayevsky, I.; Geva, S.; and Stern, E.

1989

Hazor III-IV: An Account of the Third and Fourth Seasons of Excavations, 1957-1958, Text. Jerusalem: Magnes. 